UNIVERSIDADE DE SÃO PAULO

FACULDADE DE FILOSOFIA, LETRAS E CIÊNCIAS HUMANAS

DEPARTAMENTO DE LETRAS ORIENTAIS

PROGRAMA DE PÓS-GRADUAÇÃO EM LITERATURA E CULTURA RUSSAS

NATALIA CRISTINA QUINTERO ERASSO

OS DIÁRIOS DE JUVENTUDE DE LIEV TOLSTÓI TRADUÇÃO E QUESTÕES SOBRE O GÊNERO DE DIÁRIO

EXEMPLAR CORRIGIDO

De acordo

Professor Doutor Noé Silva

Orientador 
UNIVERSIDADE DE SÃO PAULO

FACULDADE DE FILOSOFIA, LETRAS E CIÊNCIAS HUMANAS

DEPARTAMENTO DE LETRAS ORIENTAIS

PROGRAMA DE PÓS-GRADUAÇÃO EM LITERATURA E CULTURA RUSSAS

NATALIA CRISTINA QUINTERO ERASSO

OS DIÁRIOS DE JUVENTUDE DE LIEV TOLSTÓI TRADUÇÃO E QUESTÕES SOBRE O GÊNERO DE DIÁRIO

Dissertação apresentada ao Programa de Literaura e Cultura Russa do Departamento de Letras Orientais da Faculdade de Filosofia, Letras e Ciências Humanas da Universidade de São Paulo para a obtenção do título de Mestre em Letras

Orientador: Prof. Dr. Noé Silva 


\section{OS DIÁRIOS DE JUVENTUDE DE LIEV TOLSTÓI TRADUÇÃO E QUESTÕES SOBRE O GÊNERO DE DIÁRIO}

NATALIA CRISTINA QUINTERO ERASSO

\section{BANCA EXAMINADORA}

(Nome e assinatura)

(Nome e assinatura)

(Nome e assinatura) 


\section{AGRADECIMENTOS}

Ao Prof. Dr. Noé Silva, pela generosidade, em todos os aspectos, e apoio humano até o último momento desta pesquisa.

Ao Prof. Dr. Bruno Gomide, pela boa disposição e as observações precisas que ajudaram a nortear a conclusão deste trabalho.

À Profa. Dra. Elena Vássina, pela inspiração para realizar este empreendimento, pela presença permanente, pelo afeto e o estímulo incansável, e pela laboriosidade e a paixão tolstoianas.

A eles três também, pela acolhida no departamento desde a minha chegada ao Brasil.

A cada um dos professores que tornaram possível meu aprendizado da língua russa, sem o qual, este trabalho não existiria: Prof. Dr. Noé Silva, Profa. Dra. Elena Vássina, Natalia Palamarchuk, Ekaterina Vôlkova. A ela, em especial, minha gratidão afetuosa pelo estímulo de mais uma paixão russa.

A todas as pessoas que dedicaram seu tempo e paciência para ajudar a melhorar meu português, especialmente, Prof. Dr. Noé Silva, Denise Regina de Sales, Ludmila Menezes Romanovsky Inaccio, Fabiana Morabito.

À CAPES pelo apoio financeiro para a realização da pesquisa.

Sempre generosas e pacientes, Ludmila e Fabiana, amigas.

A Ludmila e Manolis, lições de vida.

A Alexandr Kornev, sem palavras. 


\section{RESUMO}

QUINTERO N. C. E. Os diários de juventude de Liev Tolstói, tradução e questões sobre o gênero de diário. 2010. 155 f. Dissertação (Mestrado) - Faculdade de Filosofia Letras e Ciências Humanas, Universidade de São Paulo, 2010.

Liev Tolstói, autor russo do século XIX, reconhecido tanto pelos acadêmicos como pelo público geral como um dos maiores romancistas da história, ao longo de mais de sessenta anos escreveu um diário paralelamente a sua vasta obra artística. No conjunto de toda a produção escrita do autor, o diário constitui a sua obra mais volumosa, contudo, quase inexplorada em língua portuguesa. O presente trabalho propõe-se aproximar o leitor brasileiro dessa faceta menos conhecida de Tolstói por meio da tradução, direta do russo, dos primeiros sete anos do diário (1847 - 1854). Observa-se o que há de particular nesse texto de Tolstói, no âmbito do diário como gênero literário e, por fim, questiona-se a possibilidade de ler o diário de Tolstói como criação artística independente ou se deve ele ser tratado como um coadjuvante na interpretação das obras literárias do autor.

Palavras-chave: 1. Liev Tolstói 2 2. Gênero de diário 3. Tradução 4. Literatura russa. 


\begin{abstract}
QUINTERO N. C. E. The youth diaries of Leo Tolstoy, translation and studies on the diary genre. 2010. 155 f. Master Thesis - FFLCH, University of São Paulo, 2010.

Leo Tolstoy, great Russian writer of the nineteenth century, recognized as one of the leading novelists in the history of the genre, both by scholars and the general public, spent over sixty years writing a diary. Throughout the vast production written by the author, this diary is his most voluminous work, yet still unexplored and almost unknown in Portuguese. This work presents a translation directly from Russian of the first seven years of the diary (1847 - 1854) and also makes a first reflection on the nature of the text which encompasses the characteristics of Tolstoy's diary related to the genre. Then it analyzes whether Tolstoy's diary can be treated as an artistic creation or as supporting text in the interpretation of literary works of the author.
\end{abstract}

Keywords: 1. Leo Tolstoy 2. Diary genre. 3. Translation 4. Russian literature 


\section{SUMÁRIO}

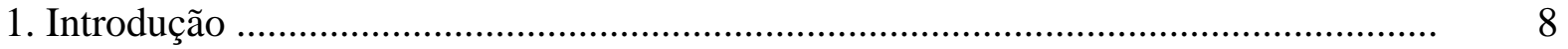

2. O diário como gênero literário

2.1 Peculiaridades do diário de Tolstói, e contraste com as características gerais do

Gênero

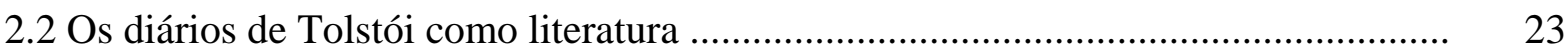

3. As edições dos diários ....................................................................................... 28

4. Tradução

Diários Liev Nikoláevitch Tolstói 1847 - 1854 .......................................................... $\quad 29$

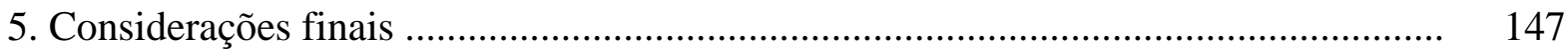

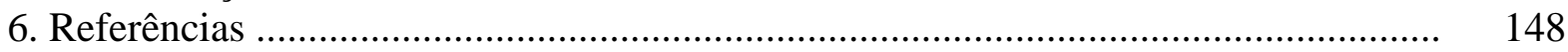

7. Anexo

Dificuldades da tradução 


\section{INTRODUÇÃO}

Empreender um trabalho de tradução e comentário acerca de qualquer obra de Liev Nikoláevitch Tolstói dispensa justificativas, em vista do reconhecimento do grande autor russo. Porém, justamente a extensão e complexidade da sua obra colocam um desafio importante diante do estudioso. Primeiro, que obra tomar para apreciação e que tema tratar, como extrair o máximo do material. Na presente pesquisa, a decisão de estudar os diários do período de juventude de Tolstói respondeu tanto a questões de ordem prática (não há traduções diretas, em português, dos diários de Tolstói) como a certo senso lógico (Tolstói começa a escrever diários aos 18 anos, antes de aventurar-se na Literatura, dedica-se a eles em paralelo à ficção e só os interrompe às vésperas da morte); o motivo decisivo, porém, é que neles é possível assistir ao processo de nascimento do escritor, "a experiência literária de Tolstói nasce da auto-observação, dos diários" (Eikhenbaum, 1999, pag. 14). O estudo dos diários de Tolstói impõe-se não unicamente pelo fato de serem a primeira "experiência" escrita do futuro romancista e pensador, mas pelo fato de eles conterem a busca de uma poética própria.

Por causa do volume do diário de Tolstói ${ }^{1}$, inicialmente, este trabalho pretendia apresentar uma seleção de fragmentos, escolhidos sob o critério de um período de tempo (a juventude) e de uma linha temática específicos. Pensou-se, inicialmente, que o conceito de amor de Tolstói poderia ser um bom tema para selecionar os fragmentos a serem traduzidos, porque é este um assunto onipresente nas obras artísticas de Tolstói e, por outro lado, porque a leitura dos diários em conjunto, mostra também que é uma questão central do pensamento tolstoiano. Contudo, o processo de tradução alterou significativamente este rumo. Desde o início, verificou-se que optar por uma linha temática como critério para a tradução, empobrecia notavelmente a possibilidade de aproveitar o material traduzido em pesquisas futuras, porque

[en los diarios] han quedado registradas sus reflexiones, sus inquietudes, su deseo de perfeccionamiento, la historia de su matrimonio y la búsqueda de un estilo literario. Las páginas del diario dan testimonio, además, de sus lecturas, de sus viajes y de las relaciones con quines lo rodeaban. Pero más allá de todas las noticias que puedan ofrecernos las páginas del diario, [éste] refleja una búsqueda constante de la conciencia”(Ancira, 2001, pag. 10) ${ }^{2}$.

\footnotetext{
${ }^{1} \mathrm{Na}$ mais recente edição das obras de Liev Tolstói, atualmente em preparação pelo Instituto de Literatura Mundial em Moscou, os diários constituem 13 dos 100 volumes que comporão a coleção.

${ }^{2}$ Quando houver citações em espanhol, serão destacadas em letra cursiva, a fim de facilitar a leitura.
} 
Contudo, diante da necessidade de limitar o material para ser traduzido, manteve-se o critério temporal e trabalhou-se com os diários de juventude de Tolstói. Apareceu então, o problema de definir que período da vida de Tolstói tomar como a sua juventude. O fundamento dessa decisão foi não a idade mas, levando em consideração a leitura dos diários em seu conjunto, o momento em que é possível apontar uma mudança importante, o fim de uma etapa e o começo de outra, na vida pessoal e nas buscas artísticas do reconhecido autor. Traduziu-se, portanto, a partir do momento em que Tolstói começa a escrever o diário em 1847, até 1854, ano em que completou 26 anos, porque

o começo do caminho já foi percorrido: foram determinadas as bases das tendências artísticas, tornaram-se conscientes os problemas principais, deu-se o desvio da tradição romântica, foi traçado o sistema dos procedimentos estilísticos e compositivos [já] o complexo e interessante período (1855-1862) exige uma pesquisa à parte para a qual é necessária o conhecimento dos diários e dos manuscritos (Eikhenbaum, 1987, pag. $127-129)^{3}$.

À época do início da presente pesquisa, dispúnhamos apenas, em língua original, da seleção dos diários em dois tomos, pertencentes às Obras Reunidas de Liev Nikoláevitch Tolstói, em 20 tomos, publicados pela editora Khudojestvennaya Literatura em 1965. Definido o período a ser traduzido, realizou-se uma primeira versão de tradução a partir dessa edição. Mas já a primeira leitura e tradução revelaram um problema fundamental: a certeza da existência de grandes cortes em relação ao texto integral, tornou evidente que a nossa percepção tanto dos traços estilísticos, como das ideias contidas no diário, não podiam ser completas, pois

Para ter uma imagem certa sobre o esclarecimento gradativo da consciência [de Tolstói] é importante saber, logo de início, que períodos de estagnação e desenvolvimento da alma distinguia ele na sua vida passada e como os avaliava nos últimos anos, ao olhar para o caminho por ele percorrido (Tchertkov, 2009, pag. VII).

Assim, já a primeira tradução redefiniu o rumo da pesquisa em procura de um tratamento mais apropriado do texto traduzido. Visto que não se tratava já de um material com uma linha temática restrita, foi necessário empreender uma aproximação mais geral, capaz de definir o fenômeno literário com que nos deparamos. Conscientes de estarmos diante de um texto de não-ficção, procuramos por materiais teóricos que permitissem compreender o

\footnotetext{
${ }^{3}$ Aqui e doravante, tradução nossa.
} 
lugar de textos dessa natureza no processo de estudo da obra de um autor e, no âmbito dessa análise, observamos que elementos fazem dos diários de Tolstói uma obra singular no seu gênero, a fim de pensar também se podem os diários serem lidos como uma obra literária autônoma. Nesse processo de busca teórica, descobriu-se um terceiro problema em relação à primeira fonte utilizada para tradução: é possível constatar divergências importantes de uma edição para outra dos diários em língua russa. Assim, por exemplo, ao lermos as citações que L. E. Buchkánets faz dos diários de Tolstói a partir das Obras completas em 90 tomos, identificamos, imediatamente, diferenças freqüentes em relação à edição das Obras Reunidas de Tolstói em 20 tomos (que foi utilizada para realizar primeira versão da tradução pertinente a esta pesquisa). Na edição citada por Buchkánets pode ler-se

Дойду ли когда-нибудь до того, чтобы не зависеть ни от каких посторонних обстоятельств? По моему мнению, это есть огромное совершенство; ибо в человеке, который не зависит ни от какого постороннего влияния, дух необходимо по своей потребности превзойдет материю, и тогда человек привыкнет к своему назначению

Chegarei eu, um dia, a não depender de nenhuma circunstância alheia a mim? A meu ver, isso é uma enorme perfeição, porquanto, na pessoa que não esteja sujeita a nenhuma influência alheia, o espírito, sem falta, pelas suas necessidades, superará a matéria e então o homem se acostumará a seu destino

ao passo que na edição em 20 tomos Tolstói parece afirmar que quando o homem está livre do influência alheia, ele alcança, atinge seu destino, não se acostuma a ele:

Дойду ли когда-нибудь до того, чтобы не зависеть ни от каких посторонних обстоятельств? По моему мнению, это есть огромное совершенство; ибо в человеке, который не зависит ни от какого постороннего влияния, дух необходимо по своей потребности превзойдет материю, и тогда человек достигнет к своему назначению

Chegarei eu, alguma vez, a não depender de nenhuma circunstância alheia? Em minha opinião, isto é uma enorme perfeição, porquanto, no homem que não depende de nenhum influência alheio, o espírito, pelas suas exigências, necessariamente superará a matéria e então o homem alcançará seu destino.

Em outra passagem também citada por Buchkánets, aparece a seguinte diferença:

Ежели мой переход из клиники домой мог произвести на меня такое влияние, какое же влияние произведет на меня мой переход из жизни студенческой к жизни помещичьей? Перемена в образе мысли должна произойти.

Se a minha vinda da clínica para casa pôde ter em mim tal influência, que influência terá então sobre mim a passagem da vida de estudante para a vida de proprietário de terras? Uma mudança no modo de pensar deve acontecer. 
Na edição usada para a nossa tradução, Tolstói afirma que deve acontecer uma mudança no estilo de vida e não no modo de pensar.

Ежели мой переход из клиники домой мог произвести на меня такое влияние, какое же влияние произведет на меня мой переход из жизни студенческой к жизни помещичьей? Перемена в образе жизни должна произойти.

Se a minha vinda da clínica para casa pôde ter em mim tal influência, que influência terá então sobre mim a passagem da vida de estudante para a vida de proprietário de terras? Uma mudança no modo de vida deve acontecer.

Muitas mais diferenças desse tipo foram achadas, e quase sempre correspondiam a apenas uma palavra divergente, mas é claro que as variações apontadas dizem respeito ao sentido do pensamento de Tolstói e compreende-se em seguida que, na tentativa de tratar algum aspecto dele, é imperioso o trabalho com o material mais próximo possível do original, a fim de poder esclarecer quaisquer dúvidas.

Graças à indicação do Professor Igor Leonidovitch Vólguin, tivemos acesso à edição das obras de Tolstói em 90 tomos (a mais recente e completa edição das obras de Tolstói na atualidade), disponíveis em http://petrovitskaya.lifeware.ru/sobranie sochineniy. Com a aquisição desse material, começou uma segunda etapa no desenvolvimento do trabalho. Realizou-se um cotejo da primeira tradução com a nova edição disponível, e completou-se a tradução com o acréscimo da maior parte dos fragmentos omitidos na edição de 65 porque, como afirma Vladímir Tchertkov acerca do processo de preparação para publicação dos materiais deixados pelo autor de Anna Kariênina, "nos escritos de Tolstói tudo é necessário" (Tchertkov, 2009, pag. XI). 


\section{O diário como gênero literário}

2.1 Peculiaridades do diário de Tolstói, e contraste com as características gerais do gênero.

\section{DIÁRIO}

5. Rubrica: literatura.

Obra em que o autor relata cronologicamente fatos ou acontecimentos do dia-a-dia, consigna opiniões e impressões, registra confissões e/ou meditações etc.

Ex.: o d. que ele está escrevendo vai dar o que falar

Definía Baroja la novela como "un saco donde cabe todo"; la definición parece, mucho más que a la novela, [...] convenir al diario. Laura Freixas. Auge Del diario ¿íntimo? en España.

Boris Eikhenbaum afirma que "O estudo da obra de Liev Tolstói deve iniciar-se pelos seus diários" (Eikhenbaum, 1987, pag. 36), porque "O jovem Tolstói é um ciclo natural não só cronológica, mas significativamente. Aqui se esclarecem as bases da tradição literária de Tolstói, aquilo de que ele se afastava, como de um chavão e aquilo para o que tendia, como para um modelo" (pag. 34).

O problema fundamental que se apresenta ao empreender esse caminho de análise da obra de Tolstói é, que fazer, como tratar esses diários, pois salta logo à vista do leitor, que os diários de Tolstói são um filão inesgotável de temas e idéias que se encontram, de forma fácil e recorrente, nas suas obras artísticas. Mas, que relações estabelecer entre os acontecimentos narrados no diário e as obras literárias? É pertinente tentar estabelecer essas relações? E, podem os diários ser lidos e analisados como obra independente? Mais ainda, podem os diários ser considerados uma obra?

Como assinala Irina Paperno (2004), não raro, diferentes diários tem sido objeto de estudo, porque eles parecem uma fonte imediata de acontecimentos históricos (tal, por exemplo, o interesse comum no que tange ao diário de Anna Frank) ou de dados biográficos (tal o caso do diário de Anais Nin, por exemplo). E também os diários em si, como forma 
particular de narração, "as a complex form that shapes the representation of experience into a whole" (Paperno, 2004, pag. 561), isto é, como gênero literário, tem sido objeto de estudo de diversos autores. Em princípio, os estudiosos se preocupam por como limitar, como definir o que é um diário (Girard, Paperno, Bobrova).

Para tanto, os estudos históricos tentam estabelecer o momento de em que aparece essa forma literária. Nina Bobrova, tanto como Irina Paperno e Laura Freixas, vê as raízes do diário íntimo, como gênero literário, nas formas de relato em que a narração está ligada a certa seqüência temporal, e onde o conteúdo é basicamente não inventado, portanto, não ficcional: é o relato dos fatos da cotidianidade realmente vivida ou presenciada por alguém, sem que interessem as experiências subjetivas de quem escreve esse relato. Trata-se das crônicas e anais, ao estilo das crônicas da conquista da América, por exemplo. Para as autoras, o que diferencia imediatamente o diário íntimo de seus antepassados literários é a irrupção da introspecção no âmbito da narração dos acontecimentos cotidianos.

From this perspective, the modem diary has been described in terms of its significance in the individual psychological and general philosophical sense: used to account for one's time, the diary stems from the fear of watching life grow shorter with each passing day ${ }^{4}$. Moreover, as it turns life into text, the diary represents a lasting trace of one's being - an effective defense against annihilation. In this sense, diarists use the "account book" and, broader, the "book of (my) life" as the governing metaphors of diary-writing (Paperno, 2004, pag. 563).

Essas opiniões são coerentes com a análise de Nina Bobrova quem, no contexto específico da Rússia, vê as origens do diário ligadas ao gênero das romarias dos séculos IX $\mathrm{X}$, por ser típico dele o elemento autobiográfico e o que ela denomina "documentalismo" e “factografismo" (2007, pag. 7). Mas para chegar ao diário moderno, foi preciso

O despertar da auto-consciência histórica do indivíduo, [que] propiciou o surgimento, no final do século XVII, dos primeiros diários de escritores. A difusão da forma do diário nas literaturas russa e européia do século XVIII está relacionada com sentimentalismo que formou as bases das variedades de diário como forma de narrativa literária. Os acontecimentos históricos do início do século XIX, introduziram o conceito da participação pessoal dos autores de diários no

\footnotetext{
${ }^{4}$ Corbin,"Backstage", 498. Corbin wrote of nineteenth-century diaries.
} 
desenvolvimento da História. Para meados do século XIX, formam-se as variedades de diário e conclui-se o processo de cristalização do gênero. No curso dessa evolução, constituíram-se formas produtivas da escrita de diário: a forma literária na obra artística e as notas extra-literárias de caráter particular (Bobrova, 2007, pag. $6)^{5}$.

É esse exatamente o ponto de partida da análise de Alain Girard, quem localiza o surgimento do diário como gênero literário por volta de 1800 , como resultado da interação entre as tendências dominantes do pensamento da época, marcado pela moda das confissões ao estilo de Rousseau e o racionalismo pré-romântico. Girard observa que a nova situação do homem dentro de uma sociedade que pretende privilegiar o indivíduo é frustrante na medida em que esse indivíduo se sente imerso na massa da sociedade, o que suscita nele a necessidade urgente de diferenciar-se, ser único, verdadeiramente um indivíduo. $\mathrm{O}$ homem que tenta responder a essa nova exigência social, precisa construir uma imagem do eu. A prática de escrever diários difunde-se porque "entre todos los textos escritos, ninguno puede informar mejor sobre la imagen del yo que los escritos en primera persona"(Girard, 38). O diário é, na modernidade, a única coisa que o autor sente que domina, em contraste com um mundo externo que muda rapidamente e se torna confuso perante os seus olhos. E, pelo menos até 1850, aponta Girard, o diário manteve-se restrito à esfera do íntimo porque "los primeros redactores de diarios íntimos [...] no tuvieron otra ambición, en un primer momento, que la de comprender las operaciones del espíritu, captar las relaciones de lo fisicico y lo moral y conocer mejor al hombre"(33).

Mas como afirma Irina Paperno, entre os estudiosos do diário como gênero literário, é uma opinião comum que "diary flourished in the ages and cultures concerned with the individual [but] What individuality means, and how the diarist works on himself or herself, varies depending on the historical context as well as on the concrete person" (2004, pag. 563). Assim, se bem é possível entender, conforme descreveu Girard, a escrita e consequente difusão do gênero de diário na Europa como resultado da necessidade natural do homem de dar expressão ao íntimo por causa do aparecimento da consciência histórico-filosófica dos embates da modernidade, que abalam o senso de centralidade e onipotência do indivíduo, é preciso pensar que outro é o estímulo que provoca a volta para o íntimo e torna a Rússia dessa

\footnotetext{
${ }^{5}$ Agora e doravante, tradução nossa.
} 
época rica em produção de diários ${ }^{6}$. Quando “aparecem no primeiro plano os problemas sociais e da propriedade [e] os problemas do indivíduo passam para o segundo plano [...], a biografia particular perde a sua tensão, seu caráter heróico ou dramático; ela se torna familiar ou íntima" (Eikhenbaum, 1999, pag. 7) ${ }^{7}$.

Esse olhar para o indivíduo na esfera do íntimo é fundamental para o caráter do diário do jovem Tolstói, porque é nesse âmbito onde se gesta o que Girard chamou “operação de captar o físico e o moral e de conhecer melhor o homem”. Logo a primeira anotação do diário de Tolstói diz respeito a esse objetivo. Ele afirma ter começado a levar um diário, porque, em solidão absoluta, "nada estranho produz influência e a [sua] atividade deve necessariamente desenvolver-se" (Tolstói, 2009, pag. 3). Tolstói está em um hospital fazendo tratamento contra uma doença venérea. Sem nenhum criado à disposição e sem nada para fazer, começa a questionar seu estilo de vida e o diário nasce como o registro do proveito da reflexão solitária: "discerni claramente - a vida desregrada que a maior parte das pessoas mundanas consideram uma conseqüência da juventude, não é outra coisa que não conseqüência de uma precoce perversão da alma" (idem).

Desde o início, o diário do jovem Tolstói não se ajusta a um "modelo «de pureza de gênero»»" (Buchkánets, (...), pag. 1) entendido como

a text written in the first-person, in separate installments, ideally on a daily basis, and ostensibly for the purposes of giving an account of the writer's personal experience in a given day, which is not necessarily addressed to someone other than the diarist ${ }^{8}$ (Paperno, 2004, pag. 562. Grifo nosso).

porque o que interessa a Tolstói é não tanto contar as experiências de um dia determinado, mas o conhecimento de si próprio a fim de atingir o aperfeiçoamento moral.

\footnotetext{
${ }^{6}$ Nina Bobrova, Oleg Egorov e Mikhail Mikheev dedicam estudos ao gênero de diário na Rússia, e aos diários de escritores russos do século XIX. Essa última linha de pesquisa é seguida por Igor Vólguin, quem desenvolve, na atualidade, pesquisa dedicada aos diários de Tolstói do período de maturidade.

${ }^{7}$ Capítulo do livro Molodoi Tolstoi (Jovem Tolstói) de A. G. Ostrovski. Tradução nossa.

${ }^{8}$ The definition by Lawrence Rosenwald (who goes by the Russian Formalist categories of form and function): "In form, a diary is a chronologically ordered sequence of dated entries addressed to an unspecified audience. We call that form a diary when a writer uses it to fulfill certain functions. We might describe those functions collectively as the discontinuous recording of the aspects of the writer's own life; more technically we must posit a number of identities:between the author and the narrator; between the narrator and the principal character; and between the depicted and the real, this latter including the identity between date of entry and date of composition." Rosenwald's definitionis meant to exclude the neighboring genres, such as memoir and autobiography, letter and correspondence, and fictitious diary (or diary-novel). See Lawrence Rosenwald, Emerson and the Art of the Diary (New York, 1988), 5-6. For an extensive discussion of definitions of the diary see Andrew Hassam, Writing and Reality: A Study of Modern British Diary Fiction (Westport, CT, 1993), 11-23.
} 
Assim, ainda que as anotações sejam datadas, e sejam mencionadas atividades feitas ou por fazer, tais atividades são descritas ali porque elas têm objetivos muito específicos:

Exatamente daqui a uma semana, vou para a aldeia. Que fazer então durante esta semana? Estudar inglês e latim, direito romano e as regras. Exatamente: ler "Vicar of Wakelfield ${ }^{9}$, procurar o significado das palavras desconhecidas, e estudar a primeira parte da gramática; ler a primeira parte das Instituições ${ }^{10}$ para melhor conhecimento tanto da língua quanto do direito romano, terminar as regras da formação interior e recuperar o perdido para Lila no xadrez (Tolstói, 2009, pag. 29).

Esta é a primeira anotação mais típica de diário, no sentido amplo descrito por Paperno, e aparece apenas em 7 de abril de 1847, um pouco mais de um mês depois de Tolstói ter iniciado seu diário, em 17 de março. Antes desse momento, não aparecem listas de atividades nem o relato de uma experiência correspondente a um dia específico. $\mathrm{O}$ diário de Tolstói parece, no começo, o texto de uma pessoa que, por não ter outra coisa para fazer, escreve, e no cabeçalho do seu texto anota uma data. Quando Tolstói reflexiona pela primeira vez sobre a natureza do texto que escreve e se pergunta acerca da utilidade de escrever um diário, começam a aparecer as listas de atividades e as impressões sobre os efeitos de cada coisa realizada. Mas o importante é observar, que toda vez que há um relato de atividades, aparece ali como instrumento da realização de um objetivo específico. Por isso, no primeiro momento que reflete sobre o diário escreve: "Nunca tive um diário porque não via nenhuma utilidade nele. Mas agora, que estou empenhado no desenvolvimento das minhas capacidades, com um diário, estarei em condições de julgar o curso desse desenvolvimento." (2009, pag. 29). E as tarefas que se propõe têm o caráter de pequenos e constantes exercícios tendentes ao desenvolvimento de capacidades determinadas, mas de tal forma que cada atividade cumpra não só com objetivos específicos, mas que contribua para a realização de um objetivo geral mais amplo. No trecho citado, por exemplo, é interessante ver como as atividades que se propõe o jovem Tolstói, ainda não escritor, confluem todas para o aperfeiçoamento da língua: ler a primeira parte do código de direito romano é útil para o aprendizado do direito em si, o que era necessário para Tolstói porque naquela época havia começado a carreira de direito na Universidade de Kazan, mas em um sentido mais amplo, é útil para ele como exercício para o aprimoramento da língua. Ler Vicar of Wakelfield é proveitoso para aprender as palavras desconhecidas em inglês, e estudar inglês, latim e gramática, tudo está vinculado a esse aperfeiçoamento. Mas com certeza, para Tolstói não é apenas questão de tentar conseguir a

\footnotetext{
${ }^{9}$ Romance de Oliver Goldsmith (N. de T.).

${ }^{10}$ As Instituições são a primeira parte do código de leis do imperador bizantino Justiniano. Com elas iniciava-se o curso de direito romano nas universidades (N. de T.).
} 
perfeição em uma atividade ou outra. Ele está empenhado no estabelecimento de um sistema, que lhe ajude a definir e depois atingir o objetivo da sua vida: "Qualquer que seja o ponto de partida do meu raciocínio, o que quer que eu tome como sua fonte, eu chego sempre à mesma conclusão: o objetivo da vida do homem é contribuir, de todas as maneiras possíveis, para o desenvolvimento multilateral de tudo o que existe" (Tolstói, 2009, pag. 30). E desde o início, ele está convencido de que para tanto, é indispensável manter um desenvolvimento equilibrado:

Em mim começa a manifestar-se a paixão pelas ciências. Embora das paixões humanas essa seja a mais nobre, eu, ainda assim, nunca me entregarei a ela de forma unilateral, isto é, matando por completo o sentimento e não me ocupando em aplicá-la e unicamente aspirando à formação da inteligência e ao preenchimento da memória. A unilateralidade é a causa principal das desgraças do homem. (pag. 7).

E como o diário se constituiu no instrumento de avaliação desse processo, ali Tolstói anota a percepção de si próprio, sempre em relação ao cumprimento de atividades traçadas ou de sugestões de comportamento. No começo, elas aparecem como máximas que Tolstói formula para si, com o caráter de um guia filosófico para a vida:

O retiro é tão útil para o homem que vive em sociedade, como a vida social é para o homem que não vive nela. Separe-se o homem da sociedade, retraia-se ele em si, e tão logo o juízo lhe arranque os óculos que lhe mostravam tudo numa forma distorcida, e tão logo se aclare a sua maneira de ver as coisas, então, será para ele incompreensível como não via tudo aquilo antes. Deixa o intelecto agir, ele te mostrará o teu destino, ele te dará regras com as quais poderás entrar sem medo na sociedade.

Tudo o que estiver em conformidade com a faculdade principal do homem, a razão, estará também em conformidade com tudo o que existe. A razão de uma pessoa isolada é parte de tudo o que existe, e a parte não pode destruir a ordem do todo. Já o todo pode matar a parte.

Para isso, forma teu intelecto de maneira que esteja de conformidade com o todo, com a fonte de tudo e não com a parte, com a sociedade das pessoas. Então, teu intelecto fundir-se-á com o todo e então a sociedade, como parte, não terá influências sobre ti. (pag. $3-4$ ).

Mas nesse processo de avaliação permanente da própria conduta, Tolstói compreende logo que "é mais fácil escrever dez volumes de filosofia do que pôr qualquer princípio em prática" (pag. 4), e inicia o que Eikhenbaum chama "um trabalho na metodologia da introspecção como etapa preparatória para a criação artística” (1987, pag. 48). Segundo ele, "é como se Tolstói admirasse o acabamento, a coerência e a aparente incontrovertibilidade que adquire o pensamento passado pelo aparato lógico" (idem) e Tolstói decide então que um sistema de regras pode ajudar-lhe a cumprir com seus objetivos: 
Eu mudei muito, mas ainda não consegui esse grau de perfeição (nas minhas ocupações) que gostaria de alcançar. Não cumpro aquilo que me prescrevo. O que cumpro, cumpro mal e não cultivo a memória. Por isso, escrevo aqui algumas regras que, parece-me, muito me ajudarão, se as seguir (Tolstói, 2009, pag. 15).

E assim, entre março e maio de 1847, Tolstói escreve, paralelamente às tradicionais anotações datadas de diário, um caderno com uma série de regras que se tornam as suas Tábuas da Lei, e o diário é a constatação regular dos resultados da aplicação desses mandamentos por ele inventados:

18 de abril. Escrevi de repente muitas regras, e quis segui-las todas; mas não tive forças para isso. Agora, quero prescrever-me só uma regra e adicionar outra a ela somente quando estiver acostumado a seguir a primeira. A primeira regra que me prescrevo é a seguinte. $\mathrm{N}^{\mathrm{o}}$ 1: Realiza tudo o que tiveres determinado realizar. Não consegui cumprir a regra. (pag. 32).

E se, como afirma Eikhenbaum, os anos de juventude de escrita do diário são para Tolstói "não tanto um trabalho sobre a maneira de ver o mundo, não tanto autoconhecimento e análise de si [como] um período preponderantemente metodológico” (1987, pag. 48), o caderno de regras é, por excelência, o lugar do diário onde fica evidente tal método. As regras redigidas por Tolstói revelam a sua compreensão da natureza humana cindida entre o corpóreo e o imaterial ${ }^{11}$ e constituem o mecanismo, o método achado por ele para dominar essas duas esferas da vida. De novo, a aspiração de Tolstói é o desenvolvimento gradativo e harmonioso das partes. Aqui, não há uma seqüência temporal senão uma série de assuntos que se constituem em regra de vida, conforme Tolstói consegue organizar os resultados da autoobservação em uma escala gradativa que vai do mais baixo ao mais elevado da natureza humana. Assim, começa o caderno com as "Regras para o desenvolvimento da vontade corporal", já que a sua satisfação corresponde ao conjunto das necessidades imediatas do homem. E como identifica que "os sentimentos e a razão têm influência sobre a vontade corporal" (2009, pag. 266), o próximo conjunto de regras tem a ver com o desenvolvimento da vontade afetiva. Dentro da vontade afetiva, Tolstói determina que a única fonte de todos os sentimentos é o amor em geral, e que o amor está dividido em amor-próprio e amor por tudo o que nos rodeia, então ele passa a formular regras para a submissão do sentimento de amor próprio à vontade e assim por diante em uma seqüência que abrange e revela toda a concepção tolstoiana dos elementos que constituem a natureza humana. Oito anos mais tarde, Tolstói reavalia esse método, e confirma sua convicção na natureza cindida do homem e na necessidade do desenvolvimento progressivo:

\footnotetext{
${ }^{11}$ Tolstói fala sobre capacidades da alma, disposição de espírito, sentimentos entre outros assuntos.
} 
Reli as páginas do meu diário em que me examino e procuro um caminho, ou um método de aperfeiçoamento. Desde o próprio começo, eu tomei o método mais lógico e científico, mas o menos possível de todos: conhecer e atingir, por meio da razão, as melhores e mais úteis das virtudes. Depois compreendi que a virtude é a negativa ao vício, uma vez que o homem é bom. E eu queria emendar-me dos vícios. Mas eles eram demais, e a correção, por meio de um princípio espiritual, seria possível para um ser espiritual, mas o homem possui dois seres, duas vontades. Então entendi que na correção é necessária a progressão. Mas também isso é impossível. É necessário, por meio da razão, preparar uma situação em que seja possível o aperfeiçoamento e em que coincidam, ao máximo, a vontade carnal e a vontade espiritual ${ }^{12}$. Certos procedimentos são necessários para a correção. E num deles caí eu por acaso. Achei o critério das situações em que o bem é fácil ou difícil. O homem, em geral, tende para a vida espiritual e para a consecução dos objetivos espirituais, é necessária tal situação em que a satisfação das inclinações carnais não contradiga, ou então que coincida com a satisfação das inclinações espirituais (pag. 38 - 39).

Assim, apesar de que no sucessivo aparecerão com mais freqüência anotações sobre atividades e horários, o diário do jovem Tolstói resulta ser, essencialmente, “o registro de meditações filosófico-estéticas [e com freqüência], as observações acerca da própria vida são, imediatamente, interpretadas como manifestação de uma norma humana geral" (Buchkánets, (...) pag. 2). Nesse aspecto, o diário do jovem Tolstói reflete o movimento de conhecer o homem "no en su individualidad, sino en su universalidad"13, e por essa via, as reflexões anotadas por ele adquirem um caráter sentencioso porque

desde os anos juvenis [Tolstói] sente a necessidade de uma certa atividade que possua caráter moral-civilizador ou predicador [...] as verdades morais, "regras" que ele considera eternas, universais e imutáveis constituem objeto permanente das suas reflexões e tema para as conversações e formulações (Eikhenbaum, 1999, pag. 16).

Tal como apontam Eikhenbaum e Buchkánets, em grande parte, a tendência tolstoiana a organizar o pensamento em máximas de caráter universalizante, revela seu parentesco com o pensamento do século XVIII; “é um fenómeno orgânico e lógico ${ }^{14}$, que as literaturas inglesa e francesa dessa época constituem sua leitura principal e preferida [...] Rousseau e Sterne, os guias espirituais da época de Karamzin e Jukóvski, resultam ser seus escritores preferidos"

\footnotetext{
${ }^{12}$ A esse respeito, afirma Buchkánets “Tolstói chega à compreensão de que a idéia "pode tornar-se o verdadeiro objetivo da vida somente quando ela não for apenas algo de que o sujeito tiver tomado consciência", e sim também "algo que penetrar profundamente na alma. A idéia, gerada pela razão, torna-se convicção quando percebida com toda a alma, com todo o coração"; de que "a penetração na essência do fenômeno pela razão e pelo coração de forma simultânea significa o grau superior de manifestação da consciência", e de que o sentimento é o indicador do grau de penetração do homem na essência do fenômeno da vida humana. (Buchkánets e Morozenko apud Buchkánets, pag. 7).

${ }^{13}$ Laura Freixas afirma que o encontro de duas tendências foi necessário para o aparecimento do diário íntimo como gênero literário: a introspecção e o desejo de conhecer o homem "no en su individualidad sino en su universalidad”. Vide, Amiel, Henri-Frédéric. En torno al diario íntimo. Tradução e prólogo de Laura Freixas.

14 Eikhenbaum mostra ainda, como essa influência é palpável no próprio estilo do Tolstói dessa época. Em alusão à pergunta e resposta de Tolstói acerca do objetivo da vida (vide tradução dos diários, 17 de abril de 1847), Eikhenbaum afirma: "A própria sintaxe desse raciocínio, a repetição "Se eu começar a" e "se eu me ponho a", as próprias expressões e o estilo geral, tudo é típico dos sistemas filosóficos do século XVIII" (1987, pag. 39).
} 
(Eikhenbaum, 1987, pag. 40), mas não são a única influência perceptível no jovem Tolstói. "Ele incluso não é alheio à tradição sentimental" (idem) e a idéias de diversas épocas, de outras gerações, porque, como afirma Eikhenbaum, "arcaísmos e anacronismos entram na construção de cada época [...] Tolstói foi esse arcaísta beligerante que observava a contemporaneidade com o olhar de uma pessoa de outra época, ou épocas". E a própria estrutura do diário reflete o caráter do pensamento tolstoiano. Do seu diário pode afirmar-se que abrange todas as funções que o gênero experimentou em momentos históricos diversos, em correspondência com as necessidades reflexivas de seu autor, que não podem ser presas a uma determinada época.

Thus, in the late seventeenth and eighteenth century, Puritans and Pietists used diaries to monitor the sinful self and (as far as the Pietists are concerned) to bring about an internal conversion that led to salvation. In the age of the Enlightenment and Sentimentalism, diarists widely used psychological introspection for the purposes of moral self-perfection and cultivation of feeling. In the second part of the nineteenth century, positivism encouraged the use of the diary for scientific self-observation, tracing the connections between the physical and the psychological, external circumstances and sensation (Paperno, 2004, pag. 563) ${ }^{15}$.

Do diário de Tolstói pode afirmar-se, inclusive, que entra nele aquela função que os estudiosos apontam para o diário no século XX, em que

diary -without losing its earlier meanings- absorbed the modernist impulse for deliberate self-creation, whether in an aesthetic or in a political key [...]diaries over the course of time have been invested (by the diarists themselves, or their publishers and readers) with an aesthetic value and function, becoming works of literature.' The diaries are seen as having a high potential for self-reflexivity and for thematizing the very act of writing.

Como afirma Buchkánets, o “objetivo do diário determina seu estilo na correspondente etapa da sua escrita" (pag. 3). Isso explica o caráter "intermitente" (Buchkánets, Eikhenbaum) do diário. "Tolstói faz apontamentos durante um certo pequeno intervalo de tempo e depois perde o interesse e o diário interrompe-se por meses, às vezes anos ${ }^{16}$.

Assim, o primeiro ano de escrita do diário interrompe-se abruptamente em junho de 1847 e Tolstói só a retomará 3 anos depois, em junho de 1850. Segundo Buchkánets,

\footnotetext{
${ }^{15}$ Exemplos relativos a essas funções presentes no diário do jovem Tolstói serão fornecidos em uma versão definitiva do capítulo.

${ }^{16}$ Esta particularidade conserva-se nos Diários posteriores de Tolstói. Como escreveu V. Dneprov, os Diários são especialmente necessários a Tolstói em "tempos de esperança, medo e angústia. Eles lhe dão alívio, tornam mais ligeira a passagem para o equilíbrio e para o sossego criativo [...] Depois dessas palavras, que comprovam que o estado exigido foi alcançado, a escrita dos diários suspende-se por alguns anos". (Dneprov, 1978 apud Buchkánets, --? Pag. 3).
} 
Quando uma nova etapa se torna consciente para Tolstói, chega o momento de voltar ao diário para fixá-la. Quando um dado momento de desenvolvimento é esgotado e fixado, o interesse pelo diário se perde, em que pese a forte intenção de fazer anotações a cada dia. Os diários reiniciam-se em um novo ponto de "tensão argumental (--?, pag. 3)

em que o relato de atividades é secundário. Por isso o diário não revela o que Tolstói fez durante esse tempo todo, apesar de ele dizer "Os últimos três anos, passados por mim tão desregradamente, às vezes me parecem muito interessantes, poéticos e, em parte, úteis; vou esforçar-me por recordá-los e registrá-los com mais franqueza e em mais pormenores” (2009, pag. 35) porque, depois de longa pausa, o que ainda interessa a Tolstói, é uma questão ética. Constantemente está insatisfeito com os resultados do seu trabalho, mas insiste na observação do seu comportamento em relação às regras, de forma que, como afirma Eikhenbaum, pelo menos entre 1847 e 1851, "por todas as partes se sente essa peculiaridade [...] não tanto a elaboração de regras e programas reais, premeditados, para execução efetiva, como a sua colocação, e depois a observação de como a alma entra em luta com eles” (1987, pag. 48): "Segundo dia de preguiça. Não cumpro o que foi traçado. Por quê? Não entendo. Porém, não me desespero, vou forçar-me. Ontem, além de não ter cumprido o determinado, ainda infringi a minha regra" (Tolstói, 2009, pag. 35). Mas, indubitavelmente, a partir da partida de Tolstói para o Cáucaso, o diário experimenta uma mudança importante, e nele aparecem de forma permanente as preocupações em relação à função do diário e a questões estéticas. Mas todas essas preocupações permanecem profundamente ligadas à ética que Tolstói vem sistematizando desde o início de seu diário e assim quando escreve

Todos descrevem as fraquezas humanas e o lado ridículo das pessoas transferindo-os a personalidades inventadas, às vezes com êxito, na medida do talento do escritor, mas na maioria das vezes, de modo artificial. Por quê? Porque nós conhecemos as fraquezas humanas por nós mesmos e para mostrá-las corretamente, é preciso que as mostremos em nós, pois uma dada fraqueza fica bem apenas a uma dada personalidade.

A poucos alcançam as forças para fazer isso. As pessoas esforçam-se por deformar o mais possível a personalidade à qual transferem as suas próprias fraquezas, para elas mesmas não se reconhecerem. Não é melhor dizer diretamente: "Eis como eu sou. Não lhes agrada, sinto muito: mas foi assim que Deus me fez". Ninguém quer dar o primeiro passo, para que não se diga, por exemplo: "acha que se você é ruim e ridículo, então todos nós também o somos". Por isso, todos se calam (Tolstói, 2009, pag. 76. Grifo nosso) ${ }^{17}$.

A sua reflexão acerca da descrição de caracteres está fortemente marcada pelo mesmo princípio filosófico de observar e conhecer em si próprio toda a natureza do homem, tal como a observara também Montaigne:

\footnotetext{
${ }^{17}$ Agora e doravante, tradução nossa. Tolstói levava, paralelamente a seu diário, diversos cadernos de anotações periódicas. Por exemplo, o livro de Franklin ou livro de debilidades, onde anotava as virtudes praticadas e os defeitos de que queria corrigir-se. A presente citação pertence ao assim chamado por ele "Caderno D", que começou a levar em março de 1851 e constitui uma pausa em relação às anotações datadas do seu diário.
} 
Presento una vida baja y sin brillo, pero lo mismo da; toda la filosofía moral se puede aplicar a una vida privada y vulgar no menos que a una vida de rica sustancia: cada hombre lleva en sí la forma entera de la condición humana [...] Si las gentes se quejan de que hablo mucho de mí mismo, por mi parte me quejo de que ellas no piensen siquiera en sí mismas (Montaigne, Cap. Seg. III livro),

Essa nova etapa do diário em que aparecem "esboços de descrições, reflexões literárias" (Eikhenbaum, 1987, pag. 48) marca uma mudança importante no diário do jovem Tolstói. Tornam-se explícitas as preocupações literárias e, com elas, a consciência sobre o próprio processo da escrita do diário ganha um lugar cada vez mais importante no trabalho do autor. 


\subsection{Os diários de Tolstói como literatura}

O lema do meu diário deve ser "non ad probandum, sed ad narrandum"."

Liev Tolstói. Diário. 1854.

A ideia de escrever em livros diferentes meus pensamentos, observações e regras é muito estranha. É muito melhor escrever tudo no diário, e esforçar-me em escrever de forma regular e limpa para que ele seja, para mim, um trabalho literário e para que possa ser, para os outros, uma leitura agradável. No fim de cada mês, ao revisá-lo, posso escolher e extrair o que achar notável. Para facilidade, vou fazer um pequeno índice de cada dia em folhas separadas.

Liev Tolstói. Diário. 1853.

Oleg Egorov afirma: "quando o assunto discorre acerca do diário, com freqüência, surge primeiro a questão de para que se escreve. E ali nos convencemos de que a primeira particularidade genérica do diário consiste em princípios funcionais, em sua predestinação" (2002, pag. 5). Egorov, por exemplo, empreendeu seu trabalho sobre os diários de escritores russos do século XIX com algumas considerações gerais sobre o diário como gênero. Em sua opinião, da mesma maneira que qualquer forma de prosa artística ou não, os diários possuem leis próprias de gênero, e elementos estruturais estáveis. No interior do gênero do diário acontecem variações que dão lugar ao aparecimento de formas específicas de diário, e os diários de escritores são um gênero literário peculiar, porque neles "agrupa-se tudo o que é secreto, tudo o que é mais característico da individualidade do escritor" (2002, pag. 3). Contudo, esse caráter de depósito do secreto e do característico da individualidade, pode encontrar-se também nos diários tanto de pessoas comuns, como de pessoas notáveis de qualquer profissão. Fica portanto, ainda não resolvida a pergunta sobre a especificidade que poderia tornar os diários de escritores um gênero particular da narrativa de diários ${ }^{18}$.

\footnotetext{
* Em latim no original. Não para demonstrar, mas para narrar.

18 A definição dos "diários de escritores" como um gênero singular específico não é o objeto da presente pesquisa, porque exige a leitura comparada dos diários de diversos escritores, a fím de estabelecer a existência de traços compositivos comuns que permitam demonstrar a existência de um fenómeno narrativo específico. Aqui interessa apenas discutir se é possível encarar o diário de Tolstói como uma obra em si que, para além de ser, como afirmam Boris Eikhenbaum e Nina Burnacheva, assim como Igor Vólguin, o texto que permitiria estabelecer os protótipos das personagens fictícias, e a tradição literária do autor, por ele conter as impressões de Tolstói acerca de suas leituras ao longo da vida, é um texto com uma história e características narrativas próprias que permitem também considerá-lo como uma obra autónoma -portanto, digna de leitura independente- no conjunto da criação tolstoiana.
} 
Mas pensando nos diários, em geral, Egorov afirma que "os diários não são uma obra de arte no sentido que, o que menos há neles é algo de artístico, de artificioso" e acrescenta, “os diários não se compõem, eles se escrevem ${ }^{19}$ ", salientando com isso a natureza imediata, não elaborada que caracteriza os apontamentos de diário.

Contudo, o fato de alguns diários terem sido interessantes para seus leitores, não como fonte histórica ou biográfica, mas como modelo de gênero em si, põe em discussão essa afirmação, pois alguns diários foram justamente importantes para certos escritores que resolveram depois escrever diários íntimos ou obras de ficção em formato de diário. Um dos casos mais reconhecidos a esse respeito é o Diário de Amiel. Na história do diário íntimo como gênero moderno ("uno de los pocos realmente nuevos -ausente de la clasificación aristotélica- en la historia de La literatura occidental" [Freixas, 1996, pag.12]), é apontado como o primeiro texto dessa natureza, que alavancou o passo do diário da esfera do íntimo para o público, e com isso, considera-se também que possibilitou "la transformación del diário en verdadero género literario" (Girard apud Freixas, 1996, pag. 18). Publicado em 1880, é claro que não pode ser tomado como um texto determinante para Tolstói, no que se refere ao caráter ou à sua iniciativa de escrever um diário. Contudo, o fato de que tenha sido a sua filha, Maria Lvova Tolstaia, quem realizou a tradução dessa obra para o russo em 1890, e de que o próprio Tolstói tenha escrito a introdução à obra é indicativo de que, ainda na maturidade, a questão do diário em si interessava a Tolstói ${ }^{20}$.

Não já um diário, propriamente dito, mas uma obra de caráter biográfico, outra composição de não-ficção, está claramente no centro da composição do diário de juventude de Tolstói. Trata-se de uma parte específica da Autobiografia de Benjamin Franklin, o "Livro de Franklin" ${ }^{21}$, cujo modelo Tolstói começou a seguir quase desde o início da escrita do seu

\footnotetext{
${ }^{19}$ Em russo, "dnievniki ne sotchiniaiutsa, a vedutsa”. Há aqui uma diferença semântica difícil de verter para o português: a ação realizada por quem escreve um diário, em russo, chama-se "vesti”, que significa levar. Não se transmite uma caracterização do tipo de trabalho que faz o autor do diário, simplesmente, que ele o faz. Já o verbo "sotchiniatsa" significa compor, redigir. Este último verbo transmite a idéia de processo de elaboração, de trabalho no texto. Quem compõe, dá forma, cria, quem "leva", ou como dissemos antes, "escreve" um diário apenas representa por meio de caracteres. Eis a diferença que Egorov quer salientar: o diário não é um tipo de texto criado e trabalhado com determinados fins artísticos.

${ }^{20}$ Laura Freixas menciona esse fato na sua introdução ao diário de Amiel, traduzido para o espanhol como En torno al diario íntimo (vide pag. 55). Em sites russos afirma-se que Tolstói fez a tradução do diário de Amiel (vide http://slovari.yandex.ru/dict/brokminor/article/1/1961.html por exemplo). Contudo, não foi possível achar o livro em russo para verificar esse fato e ter acesso à introdução escrita por Tolstói, conforme afirmações de Freixas.

${ }^{21}$ Eufrosina Dvoichenko-Markov descreve muito bem em seu artigo Benjamin Franklin and Leo Tolstoy a presença que a obra de Franklin teve na Rússia desde 1752. As ideias de Franklin foram objeto de atenção de
} 
próprio diário. E como já foi assinalado antes, dentro do diário do jovem Tolstói há uma diversidade de estilos temas e procedimentos, que levam logo a questionar se Tolstói compunha seu diário ou apenas o escrevia, como afirma Egorov. Para Buchkánets, apesar de toda a variedade que possa observar-se no diário de Tolstói, há também algo que lhe confere a inteireza (integridade) e a elegância da idéia, justamente como texto literário. No diário de 1847 e de início de 1850 existe uma "linha de enredo" (Buchkántes, pag. 3) que é processo de auto-aperfeiçoamento moral e espiritual determinado pelo conjunto de regras que Tolstói redige tanto dentro do próprio diário, como em cadernos paralelos. Por isso, para alguns estudiosos

\begin{abstract}
já se tornou lugar comum a ideia de que os diários de Lev Nikoláevitch Tolstói representam um tipo de documento histórico do nascimento de uma nova aproximação ao estudo da psicologia do homem; neles há uma constante auto-análise que tudo penetra, uma tendência ao autoconhecimento de si com o objetivo do autoaperfeiçoamento (Morozenko, apud Buchkánets, pag. 8)
\end{abstract}

mas o próprio Buchkánets considera que no diário de Tolstói mal se pode falar de "autoanálise completa e profunda" (pag. 8) e logo aponta como, com a partida para o Cáucaso, “Tolstói começa a escutar a si próprio com mais atenção, atormenta-se menos e aparecem os estudos - os esboços de outras pessoas (de Iapichka, de Knoring), a descrição desses ou daqueles acontecimentos da vida na stanitsa, esboços de gênero e paisagem” (pag. 9). As longas listas de regras de vida e balanços de comportamento, são gradativamente diminuídas e substituídas por reflexões sobre o processo de escrita. É interessante notar que, no primeiro ano do diário, Tolstói escrevia um caderno paralelo de regras e, com efeito, nesta etapa de escrita do diário é a questão ética-moral o que ocupa o lugar central das preocupações do autor. Em 1851 o centro das atenções de Tolstói muda um pouco. A questão ética não desaparece jamais, mas ele começa a ocupar-se das questões literárias. Neste período aparecem as primeiras considerações sobre a possível composição de uma novela ${ }^{22}$ e nesta etapa, o caderno paralelo de regras é substituído por outro de natureza diferente: o caderno D contém uma longa reflexão sobre as idéias expressadas por Alphonse de Lamartine acerca da imaginação e da natureza humana em seu romance Geneviève. Tolstói fala aqui, diretamente, sobre o labor literário:

personalidades como Lomonosov, Karamzin e Púchkin, quem notou a indiscutível difusão da Autobiografia de Franklin no país, por meio das publicações dirigidas aos jovens. As chamadas "Regras de comportamento" constituem um capítulo do livro de Franklin e são o modelo explícito da série de regras que Tolstói estabelece para si no seu diário. "Tolstoy continued to write his Rules even out-side of his diary. He calls them by different names. Sometimes it is a Journal of weaknesses», sometimes, a "Franklin Journal," or the "Franklin's Tables," (1952, pag. 124).

${ }^{22}$ Nesta época Tolstói concebe o plano de realizar uma obra com o nome "três etapas de uma vida". Esse projeto se materializará na trilogia Infância, Adolescência e Juventude. 
Onde estão as fronteiras entre prosa e poesia, eu nunca o entenderei. Embora exista uma questão acerca dessa matéria na filologia. Mas é impossível entender a resposta. A poesia são versos. A prosa, não são versos. Ou, a poesia é tudo exceto os papéis de negócios e os livros didádicos (Tolstói, 2009, pag. 71).

E aos poucos, não só meditações sobre a criação artística, mas descrições, pequenas histórias, canções, poesias, enfim, pequenas criações literárias nascidas da reflexão sobre o processo de escrever constituem o próprio texto do diário:

A lua acabou de sair de atrás de um montículo e iluminou duas pequenas e finas nuvenzinhas baixas. Atrás de mim, o grilo assobia seu melancólico e incessante canto. Ao longe ouve-se a rã e perto do aul ora se escuta o grito do tártaro ora o latido do cachorro. E, de novo, tudo fica calmo e, de novo, ouve-se só um assobio do grilo, e arrasta-se uma nuvenzinha levezinha, transparente do lado das estrelas longínquas e próximas. Comecei a pensar: irei e descreverei o que vejo. Mas como escrever isso. É necessário ir, sentar à mesa manchada de tinta, pegar o papel cinza e a tinta. Mancharse os dedos e traçar letras pelo papel. As letras comporão palavras e as palavras, frases. Mas acaso é possível comunicar o sentimento. Para que está tão intimamente ligada a poesia à prosa, a felicidade à infelicidade? Como se deve viver? Será que deveria esforçar-me em unir de repente a poesia com a prosa ou desfrutar de uma e depois entregar-me a viver à vontade da outra? (Tolstói, 2009, pag. 65).

E como bem observa Eikhenbaum, o interesse principal de Tolstói nesse período está no desenvolvimento das capacidades descritivas. Primeiro de paisagens (como na passagem citada) e depois, na construção do retrato físico e moral das pessoas. A primeira tentativa nesse sentido, é a descrição de Knoring, oficial amigo do seu irmão Nikolai:

Tentarei traçar um retrato de Knoring. Parece-me que descrever um homem é, na verdade, impossível. Mas é possível descrever como ele age em mim. Dizer de um homem: é um homem original, bom, inteligente, bobo, consequente e assim por diante... palavras que não dão nenhuma idéia sobre o homem e têm a pretensão de caracterizar o homem e então, com quanta frequência só desorientam [...] Como ele era amigo do meu irmão, eu concluí que não devia ser um homem mundano e como meu irmão contava pouco sobre ele, eu concluí que não devia caracterizar-se pela inteligência. Uma vez, pela manhã, meu irmão me disse: "Knoring estará aqui hoje. Como estou feliz de vê-lo". "Vejamos este janota". Pensei eu. De além da tenda, chegaram-me as expressões do encontro do meu irmão e uma voz que respondia a elas com tanta alegria: "Olá, focinhudo". Este é um homem indecoroso, pensei eu, e que não entende as coisas. Nenhum tipo de relação pode dar encanto a semelhante alcunha. [...] Knoring é um homem alto, de boa constituição, mas sem encanto. Eu reconheço que nessa compleição, há mais expressividade do que no rosto: há pessoas de compleição agradável e de compleição desagradável. O rosto é largo, de pômulos salientes que lhe dão uma certa suavidade [...] Os olhos são castanhos, grandes e possuem só duas expressões: o riso e a disposição normal. Durante o riso, eles permanecem fixos e têm uma expressão de estúpida insensatez. O resto no rosto é comum (Tolstói, 2009, pag. 67).

Mas o aparecimento de tais experiências de linguagem dista muito de dar um caráter definitivo e uniforme ao diário de Tolstói. Ele, de forma permanente, passa das atividades e planos do dia-a-dia às reflexões éticas e filosóficas e à análise da disposição da sua própria alma no determinado momento de escrita do seu diário. "A principal peculiaridade do diário 
consiste na presença de muitos tipos de gêneros autônomos [...]. Tolstói inclui nele contosminiatura, pequenos tratados ético-filosóficos, análises críticas sobre as obras de diferentes autores” (Egorov, 2002, pag. 191). Os diários de Tolstói possuem tal caráter heterogêneo, porque são eles o embrião de toda a criação futura e, nesse sentido, eles constituem as bases gerais da poética de Tolstói (Eikhenbaum, 1987, pag, 67). 


\section{As edições dos diários}

Até um tempo atrás, dispunha-se de poucas publicações integrais dos diários de Tolstói em língua russa. Vladímir Tchertkov, o mais próximo discípulo de Tolstói, preparou a edição integral dos diários durante os anos 20 do século passado. A primeira publicação desse trabalho aconteceu entre os anos 1928 e 1958 sob a supervisão da Academia de Ciências da URSS (Ancira, 2001, pg. 11) e é, até agora, a única edição integral existente (Egorov, 2002, pg. 158). A presente tradução está baseada na edição das Obras Completas de Liev Tolstói em 90 volumes, dos quais 13 correspondem aos diários. O período traduzido pertence ao volume 46 da mencionada edição que, por sua vez, é a mais recente reprodução (2009), em meio eletrônico, daquela edição preparada por Tchertkov. Além dessa edição integral, existe uma seleção dos diários publicada pela editora Khudojestvennaia Literatura em 1965 (à qual tivemos acesso) e outra seleção publicada em 1985 sob os cuidados de M. B. Khraptchenko. No processo de tradução pertinente a esta pesquisa, foi de inestimável valor o trabalho de Selma Ancira, quem publicou a primeira seleção, tradução e notas dos diários de Tolstói para o espanhol em 2001.

$\mathrm{Na}$ presente tradução, respeitaram-se os critérios de publicação da edição russa. Assim, aparecem signos que indicam corte ([...]) nos casos em que esses são assim indicados no texto russo original. A presença do signo [?] indica a presença de palavra ou fragmento ilegível no original.

As notas de rodapé foram tomadas da edição de 1965. Caso contrário, é indicado. 


\title{
4. Tradução
}

\author{
Diários \\ Liev Nikoláevitch Tolstói 1847 - 1854
}

Caderno $\mathrm{A}^{23}$

1847

17 de março. [Kazan]. Há seis dias já que ingressei na clínica e seis dias em que estou quase satisfeito comigo. Les petites causes produisent de grands effets. ${ }^{24}-\mathrm{Eu}$ apanhei uma gonorréia, entende-se, do jeito que se apanha habitualmente. E essa circunstância insignificante deu-me o impulso por causa do qual subi esse degrau em que faz tempos já tinha colocado o pé. Mas não tinha conseguido, de jeito nenhum, levar o corpo (talvez porque, sem pensar, coloquei o pé esquerdo em vez do direito). Aqui estou completamente sozinho, ninguém me incomoda, não tenho nenhum criado e ninguém me ajuda. Em conseqüência, nada influi na razão e na memória, e a minha atividade deve necessariamente desenvolver-se. O principal proveito consiste, pois, naquilo que discerni claramente - a vida desregrada que a maior parte das pessoas mundanas considera uma conseqüência da juventude, não é outra coisa senão conseqüência de uma precoce perversão da alma.

O retiro é tão útil para o homem que vive em sociedade, como a vida social é para o homem que não vive nela. Separe-se o homem da sociedade, retraia-se ele em si, e tão logo o juízo the arranque os óculos que lhe mostravam tudo numa forma distorcida, e tão logo se aclare a sua maneira de ver as coisas, então, será para ele incompreensível como não via tudo aquilo antes. Deixa o intelecto agir, ele te mostrará o teu destino, ele te dará regras com as quais poderás entrar sem medo na sociedade.

\footnotetext{
${ }^{23}$ Em 1847, quando Tolstói começa a escrever seus diários, escreve também, paralelamente, outro tipo de anotações em cadernos separados. Tolstói diferenciava esses cadernos com nomes. Os diários eram nomeados com letras do alfabeto, em ordem sucessiva, e cada caderno paralelo era diferenciado com um nome de acordo com o conteúdo. Conservam-se junto aos cadernos "A, B, C, D, e.t.c." dos diários, os cadernos de regras, de lembranças, de testemunhas, entre outros. Em ocasiões, esses cadernos eram também datados, e é possível por isso afirmar que Tolstoi escrevia esses textos de forma simultânea. De todos esses cadernos, só os cadernos de regras soem ser editados como parte integrante dos diários, devido ao caráter orgânico que a redação de regras assume no conjunto dos diários do escritor.

${ }^{24}$ Pequenas causas produzem grandes efeitos.

Nota de rodapé rasurada no original. Na minha opinião, não existem tais sociedades em que exista mais bem do que mal.
} 
Tudo o que estiver em conformidade com a faculdade principal do homem, a razão, estará também em conformidade com tudo o que existe. A razão de uma pessoa isolada é parte de tudo o que existe, e a parte não pode destruir a ordem do todo. Já o todo pode matar a parte.

Para isso, forma teu intelecto de maneira que esteja de conformidade com o todo, com a fonte de tudo e não com a parte, com a sociedade das pessoas. Então, teu intelecto fundir-seá com o todo e então a sociedade, como parte, não terá influências sobre ti.

É mais fácil escrever dez volumes de filosofia do que pôr qualquer princípio em prática.

18 de março. Li a "instrução" de Catarina e, visto que me prescrevi a regra geral de, ao ler qualquer obra séria, meditar sobre ela e anotar as suas ideias notáveis, escrevo aqui a minha opinião sobre os primeiros seis capítulos desse trabalho notável.

[...] A essência do conceito de liberdade no governo monárquico é a seguinte: A liberdade, diz ela, é a possibilidade do homem de fazer tudo o que deve fazer e não ser obrigado a fazer o que não deve fazer. Eu gostaria de saber o que ela entende pelas palavras dever e não dever. Se ela compreende por essas palavras que dever fazer é um direito natural, então disso se segue, claramente, que a liberdade só pode existir naquele Estado, em cuja legislação o direito natural não se diferencia do direito positivo. A ideia é absolutamente justa [...].

19 de março. Em mim começa a manifestar-se a paixão pelas ciências. Embora das paixões humanas essa seja a mais nobre, eu, ainda assim, nunca me entregarei a ela de forma unilateral, isto é, matando por completo o sentimento e não me ocupando em aplicá-la e unicamente aspirando à formação da inteligência e ao preenchimento da memória. A unilateralidade é a causa principal das desgraças do homem. Continuo analisando a "instrução" de Catarina [...].

A ideia de que criminosos importantes possam escolher os juízes de suas causas mostra a aspiração de Catarina a justificar o poder monárquico e demonstrar que a liberdade 
existe pelo acatamento de leis procedentes do monarca, esquecendo que a liberdade pelo acatamento de leis, que não procedem do povo, não é liberdade [...]

21 de março. No capítulo X expõem-se as regras principais e os erros mais perigosos do processo criminal.

No começo desse capítulo ela se faz uma pergunta. De onde provêm os castigos e de onde provém o direito de castigar. À primeira pergunta ela responde: "Os castigos provêm da necessidade de preservar as leis". À segunda pergunta responde também muito originalmente. Ela diz "O direito de castigar pertence só à lei e as leis só podem ser feitas pelo monarca como representante de todo o Estado". Em toda essa instrução, apresentam-se constantemente dois elementos heterogêneos que Catarina constantemente queria conciliar, a saber: a consciência da necessidade de um governo constitucional e o amor próprio, isto é, o desejo de ser a soberana absoluta da Rússia. Por exemplo, ao dizer que no governo monárquico só o monarca pode possuir o poder legislativo, ela toma a existência desse poder como um axioma sem lembrar a sua procedência. Um poder mais baixo não pode aplicar castigos já que ele é parte do todo, mas o monarca tem o direito porque ele é o representante de todos os cidadãos, diz Catarina. Mas será que a representação do povo pelo soberano nas monarquias absolutas é manifestação do conjunto das vontades particulares livres dos cidadãos? Não. A manifestação da vontade comum nas monarquias absolutas é o seguinte: eu suporto um mal menor, porque se não o suportasse, teria que me submeter a um mal maior.

[...] Nesse capítulo encontra-se uma ideia absolutamente republicana. Ela diz, justamente, que a decisão dos assuntos deve ser popular para que o cidadão reconheça a sua segurança sob a proteção das leis. Será que pode existir a segurança dos cidadãos sob a proteção das leis lá onde não só as decisões judiciárias mas também as leis mudam pelo arbítrio do autocrata? [...]

24 de março. Eu mudei muito, mas ainda não consegui esse grau de perfeição (nas minhas ocupações) que gostaria de alcançar. Não cumpro aquilo que me prescrevo. O que cumpro, cumpro mal e não cultivo a memória. Por isso, escrevo aqui algumas regras que, parece-me, muito me ajudarão, se as seguir. 1) O que tiver sido traçado para ser cumprido obrigatoriamente, cumpre-o, custe o que custar. 2) O que cumprires, cumpre-o bem. 3) Nunca consultes no livro se esqueceste alguma coisa, mas esforça-te por lembrares sozinho. 4) Obrigue com frequência a sua mente a agir com todas as suas forças possíveis 5) Leia e pense sempre em voz alta. 6) Não tenhas vergonha de dizer às pessoas que te atrapalham, que elas te 
atrapalham. Primeiro, faze que elas o sintam e, se elas não o compreenderem, então pede-lhes desculpas e fala-lhes com franqueza. De acordo com a segunda regra, quero, com certeza, terminar de comentar toda a "instrução" de Catarina" [...].

25 de março. Não é suficiente afastar as pessoas do mal. É ainda necessário estimulálas para o bem $[\ldots]$.

26 de março. No capítulo XX existem diferentes assuntos que exigem explicação. Primeiro, fala-se sobre o crime de lesa-majestade. Justamente, esse crime é uma junção de palavras e ações que tendem a causar dano ao monarca ou à monarquia. Por exemplo, quando um cidadão sai à praça e incita o povo com palavras, então ele é castigado, não pelas palavras, mas pela ação cujo princípio ou consequência foram essas palavras. Já os discursos tendenciosos contra o governo, pela dificuldade de comprovar esse crime, não devem ser punidos com a morte, como são em geral todos os crimes contra a majestade, senão simplesmente com medidas corretivas. Já cartas desse gênero devem ser punidas com a morte. Essa instrução mostra claramente que num governo despótico o monarca não pode depositar esperanças na lealdade dos cidadãos. Por quê? Porque, como no absolutismo não existe um acordo mediante o qual um indivíduo tem o direito, enquanto os cidadãos têm deveres, mas, ao contrário um indivíduo se apossa desse poder pela força, então eu digo: uma vez que tal acordo não existe no despotismo, então deveres da parte dos cidadãos não podem existir [pag $46 / 20]$.

\section{Caderno B}

\section{Diário}

[7 de abril, 8 horas da manhã]. Nunca tive um diário porque não via nenhuma utilidade nele. Mas agora, que estou empenhado no desenvolvimento das minhas capacidades, com um diário, estarei em condições de julgar o curso desse desenvolvimento. No diário deve haver uma tabela de regras e no diário também devem estar definidos meus atos futuros. Exatamente daqui a uma semana, vou para a aldeia. Que fazer então durante esta semana? Estudar inglês e latim, direito romano e as regras ${ }^{25}$. Exatamente: ler "Vicar of Wakelfield ${ }^{26}$, procurar o

\footnotetext{
${ }^{25}$ Como já foi explicado, paralelamente ao caderno de diários, Tolstói escrevia em outros cadernos que, para ele, tinham funções específicas. Um desses cadernos é o por ele chamado Jornal de Franklin. Trata-se de um conjunto de regras de comportamento que ele começou a redigir à maneira do capítulo do mesmo nome que faz parte da Biografia de Benjamin Franklin (N. de T.).

${ }^{26}$ Romance de Oliver Goldsmith (N. de T.).
} 
significado das palavras desconhecidas, e estudar a primeira parte da gramática; ler a primeira parte das Instituições ${ }^{27}$ para melhor conhecimento tanto da língua quanto do direito romano, terminar as regras da formação interior e recuperar o perdido para Lila no xadrez.

( 8 de abril. 6 da manhã) A esperança é um mal para o homem feliz e um bem para o infeliz.

Apesar de ter conseguido muito desde que comecei a ocupar-me do meu aperfeiçoamento, continuo sempre muito insatisfeito comigo. Quanto mais avançamos no nosso aperfeiçoamento, tanto mais defeitos vemos em nós, e certo estava Sócrates, quando disse que o mais alto grau de perfeição do homem é saber que ele nada sabe.

9 de abril. (6 da manhã). Estou absolutamente satisfeito comigo pelo dia de ontem. Começo a adquirir vontade corporal; mas a intelectual é ainda muito fraca. Paciência e aplicação e estou convicto de que conseguirei tudo o que quero.

17 de abril. Esse tempo todo, eu me comportei não como queria comportar-me. A causa disso foi, em primeiro lugar, a minha vinda da clínica para casa. Em segundo, o grupo de pessoas com que passei a ter mais relações. Disso eu concluí que, a cada mudança de situação, é necessário pensar bem quais circunstâncias exteriores me influenciarão na nova situação e de que forma é possível eliminar tal influência. Se a minha vinda da clínica para casa pôde ter em mim tal influência, que influência terá então sobre mim a passagem da vida de estudante para a vida de proprietário de terras? Uma mudança no modo de vida deve acontecer. Mas é necessário que essa mudança não seja obra de circunstâncias exteriores, mas obra da alma. Aqui me vem uma pergunta: qual é o objetivo da vida do homem?

Qualquer que seja o ponto de partida do meu raciocínio, o que quer que eu tome como sua fonte, eu chego sempre à mesma conclusão: o objetivo da vida do homem é contribuir, de todas as maneiras possíveis, para o desenvolvimento multilateral de tudo o que existe. Se eu começo a raciocinar quando contemplo a natureza, vejo que tudo nela se desenvolve constantemente e que cada uma das suas partes componentes contribui, inconscientemente, para o desenvolvimento das outras partes; já o homem, uma vez que é uma parte da natureza, como as outras, mas dotada de consciência, deve também, como todas as outras partes, aspirar

\footnotetext{
${ }^{27}$ As Instituições são a primeira parte do código de leis do imperador bizantino Justiniano. Com elas iniciava-se o curso de direito romano nas universidades (N. de T.).
} 
ao desenvolvimento de tudo o que existe, empregando conscientemente para isso todas as capacidades da sua alma. Se eu me ponho a raciocinar, olhando para a história, vejo que todo o gênero humano aspira permanentemente ao alcance desse objetivo. Se eu me ponho a raciocinar racionalmente, isto é, examinando apenas as capacidades da alma do homem, então na alma de cada pessoa encontro essa aspiração inconsciente que constitui uma exigência da sua alma. Se eu me ponho a raciocinar olhando para a História da Filosofia, descubro que, em toda a parte e sempre, as pessoas chegaram à conclusão de que o objetivo da vida do homem é o desenvolvimento multilateral da humanidade. Se eu me ponho a raciocinar, olhando para a teologia, descubro que quase todos os povos reconhecem um ser perfeito, e que chegar a ele considera-se como o objetivo de todas as pessoas. E assim eu, parece-me, sem erro quanto ao objetivo da minha vida, posso ter a aspiração consciente ao desenvolvimento multilateral de tudo o que existe.

Eu seria o mais infeliz dos homens se não tivesse encontrado um objetivo para a minha vida, um objetivo geral e útil; útil porque a alma imortal, havendo-se desenvolvido, transformar-se-á, naturalmente, em um ser superior e correspondente a ela. Agora, a minha vida será, toda ela, uma aspiração ativa e constante a esse único objetivo.

Agora eu pergunto. Qual será o objetivo da minha vida na aldeia ao longo de dois anos? 1) Estudar todo o curso de ciência jurídica necessário para o exame final na universidade. 2) Estudar a medicina prática e parte da teórica. 3) Estudar línguas: francês, russo, alemão, inglês, italiano e latim. 4) Aprender a agricultura tanto prática como teórica. 5) Estudar história, geografia e estatística. 6) Estudar a matemática do ginásio. 7) Escrever uma dissertação. 8) Atingir um grau médio de perfeição em música e pintura. 9) Escrever regras. 10) Adquirir alguns conhecimentos em ciências naturais. 11) Escrever artigos a partir de todas as disciplinas que vou estudar.

18 de abril. Escrevi de repente muitas regras, e quis segui-las todas; mas não tive forças para isso. Agora, quero prescrever-me só uma regra e adicionar outra a ela somente quando estiver acostumado a seguir a primeira. A primeira regra que me prescrevo é a seguinte. $\mathrm{N}^{\mathrm{o}} 1$ : Realiza tudo o que tiveres determinado realizar. Não consegui cumprir a regra.

19 de abril. Levantei-me extraordinariamente tarde e só às 2 decidi o que fazer durante o dia. 
14 de junho. Iásnaia Poliana ${ }^{28}$. Depois de quase dois meses, pego na pena para continuar o meu diário. Ah! Como é difícil para o homem desenvolver em si o que é bom, quando se encontra sob influência apenas de coisas más. Podia até não existir a boa influência, mas que também não houvesse a má, e então em cada ser o espírito predominaria sobre a matéria; mas o espírito se desenvolve de diferentes maneiras. Ou o seu desenvolvimento, em cada ser separado, constitui uma parte do desenvolvimento geral. Ou a sua decadência, em seres separados, reforça o seu desenvolvimento no quadro geral.

15 de junho. Ontem estive em boa disposição de espírito e decerto teria permanecido satisfeito comigo até a noite, se a vinda de Dúnitchka com o marido não tivesse exercido tão grande influência em mim, a ponto de me privar da felicidade de estar satisfeito comigo.

16 de junho. Chegarei eu, algum dia, a não depender de nenhuma circunstância alheia? Em minha opinião, isto é uma enorme perfeição, porquanto, no homem que não depende de nenhuma influência alheia, o espírito, pelas suas exigências, necessariamente superará a matéria, e então o homem alcançará seu destino. Eu começo a acostumar-me à primeira regra que me havia estabelecido e agora me estabeleço a seguinte: olha as mulheres, na sociedade, como um aborrecimento obrigatório da vida social e afasta-te delas quanto puderes. $\mathrm{Na}$ verdade, de quem recebemos a volúpia, o excesso de delicadeza, a leviandade em tudo e uma grande quantidade de outros vícios se não das mulheres? Quem é culpado de nos privarmos dos nossos sentimentos inatos, coragem, firmeza, sensatez, senso de justiça e outros, senão as mulheres? A mulher é mais suscetível do que o homem e por isso, em época de virtude foram melhores do que nós; já nesta época depravada, viciosa elas são piores do que nós.

\section{REGRAS PARA O DESENVOLVIMENTO DA VONTADE}

[Janeiro - fevereiro de 1847]

1 categoria. 1) Levantar-se às 5, deitar-se às 9 ou 10, e também se pode dormir 2 horas à tarde. 2) Comer moderadamente, sem doces. 3) Andar uma hora a pé. 4) Fazer tudo o

\footnotetext{
${ }^{28}$ Tolstói chegou a Iásnaia Poliana em 1 de maio de 1847.
} 
prescrito. 5) U[... $]^{29}$ uma mulher uma ou duas vezes por mês. 6) Fazer tudo por si mesmo, de acordo com as possibilidades.

2 categoria. 1) Amar todos aqueles para quem posso ser útil. 2) Desprezar as riquezas, as honras e opiniões gerais não baseadas na razão. 3) Preferir o benefício próprio à satisfação do outro e vice-versa.

3 categoria. 1) Permitir a atividade da imaginação só em caso de necessidade. 2) Concentrar toda a atenção em um único objeto. 3) Só em caso de necessidade, empreender outro assunto sem ter terminado o primeiro. 4) Dirigir a atenção só para aqueles temas que exigem reflexão. 5) Não deixar passar nenhuma ideia sem anotá-la e sem desenvolvê-la na hora do seu surgimento. 6) Durante qualquer atividade, pensar no seu objetivo. 7) Satisfazer uma necessidade só na medida que ela o exija. 8) Pensar apenas diretamente no futuro.

Regras da vida

16 de fevereiro de 1847. Kazan.

\section{Introdução}

A atividade do homem se manifesta em três relações.

1) Em relação com o Ser Supremo. 2) Em relação com os seres diferentes de si. 3) em relação consigo. Conforme essa divisão dos tipos de atividades do homem, eu divido também as minhas regras em três partes. 1) Regras em relação a Deus ou religiosas. 2) Regras em relação às pessoas ou exteriores e 3) regras em relação consigo ou interiores. A tarefa das regras em relação a Deus ou religiosas é a) definir o que é Deus, b) o que é o homem, c) quais podem ser as relações entre Deus e o homem. As regras exteriores ou relacionadas com as pessoas devem determinar: a) as regras em relação aos subordinados, b) em relação aos seus

\footnotetext{
${ }^{29} \mathrm{Na}$ sua nota introdutória à primeira edição integral das obras de Tolstói, Vladímir Tchertkov afirma que, em ocasiões, Tolstói anota com sinceridade extrema os acontecimentos tocantes a suas experiências sexuais do período juvenil. Segundo o editor, o autor chega a empregar palavras que não são apropriadas para publicação. Contudo, ele procurou publicar o texto integralmente, em respeito à vontade do autor do diário, "omitindo apenas umas poucas palavras isoladas que são absolutamente impublicáveis, assim como algumas anotações de caráter puramente fisiológico. Essas omissões e a substituição de algumas palavras por pontos no diário de juventude de Tolstói, atende ao desejo do filho mais velho de Tolstói, Serguéi Lvóvitch, durante cuja vida considero isso necessário". (Tchertkov, 2009, pag. XI). Tchertkov acrescenta ainda em uma nota: "Essas palavras são substituídas pela letra inicial e tantos pontos como letras são omitidas" (idem). Nós tentamos aplicar o procedimento de Tchertkov na tradução para o português. No caso presente, aparece no original russo a letra "y" (transliterada u), seguida por 12 pontos $($ y[.......... $)$. Pensamos tratar-se do verbo “употревлять" (upotrevliat) que traduzimos como "usar" e representamos aqui por "u[...]" (N. de T.).
} 
iguais, c) em relação aos superiores. As regras em relação consigo têm a tarefa de a) determinar: como se deve agir a) na própria formação moral ou religiosa, b) na relação com os outros e c) na educação física ou corporal.

\section{Parte I \\ Capítulo I}

Para formar um conceito de Deus, devemos primeiro olhar para as nossas capacidades anímicas e depois para a natureza. O homem encontra na alma o sentimento de autoconsciência, que tem a primazia na nossa alma; junto com ele acharemos outro sentimento tão forte como o primeiro - a consciência de um ser superior.

\section{[REGRAS]}

[Março - maio de 1847]

As regras interiores ou relacionadas à própria pessoa dividem-se em regras da educação moral e regras da educação corporal. A tarefa das primeiras é: desenvolver a vontade, a capacidade intelectual (reflexão e atividade). A vontade existe em diferentes graus de desenvolvimento, de acordo com a parte do homem sobre a qual predomina. Os três aspectos principais do seu domínio são: predomínio sobre o corpo, predomínio sobre os sentimentos e predomínio sobre a razão. Em cada aspecto do seu predomínio, ela se funde em um todo com a parte do homem sobre a qual predomina, de forma que tal parte já não existe autonomamente, mas existe apenas a vontade dotada das capacidades dessa parte do homem. Se a vontade predomina sobre o corpo, o que constitui o nível mais baixo do desenvolvimento dela, então o corpo deixa de existir de forma autônoma e passa a existir somente a vontade corporal. Se ela predomina sobre os sentimentos, então já não existirão nem o corpo nem os sentimentos de forma autônoma, mas uma vontade corporal e uma vontade afetiva ${ }^{30}$. Já se a vontade predomina sobre a razão, então a razão deixa de existir autonomamente e existe só a vontade corporal, afetiva e racional. Quando a vontade predomina sobre qualquer uma dessas partes do homem, então ela pode renunciar às exigências dessa parte. Se ela já pode renunciar, então ela pode também escolher. Se ela já escolhe, então ela também determina as atividades de cada uma dessas partes do homem; se ela determina todas as atividades do homem,

\footnotetext{
${ }^{30}$ Entenda-se "afetivo" na acepção de "relativo aos afetos, aos sentimentos"(Dicionário Eletrônico Houaiss da língua portuguesa. Versão 1.0).
} 
consequentemente, nem o corpo, nem os sentimentos nem a razão podem agir de maneira autônoma, e só a vontade pode obrigá-los a fazer isso ou aquilo. O mais baixo predomínio da vontade é o seu predomínio sobre o corpo. Achamos este nível de desenvolvimento da vontade em quase todas as pessoas; ela é a condição necessária da existência do homem, embora existam pouquíssimas exceções: a primeira infância, a decrepitude, e doenças tanto corporais como morais (apatia, anemia). A vontade corporal, embora autônoma, submete-se à influência do sentimento e da razão. O segundo grau de predomínio da vontade - o seu predomínio sobre os sentimentos ou vontade afetiva, encontra-se mais raramente. Embora a vontade afetiva seja mais elevada do que a vontade corporal, ela também sofre, não menos do que a outra, influência da capacidade superior do espírito - a razão. Já o grau superior de predomínio da vontade é o seu predomínio sobre a razão. (Quando a vontade predomina sobre a razão, então já não existem nem o corpo, nem os sentimentos de forma autônoma, e existe só a vontade racional. Esse grau de predomínio é o mais elevado grau de desenvolvimento do espírito humano. Nessa situação [predomínio] o espírito se afasta completamente do corpo, não se relaciona mais com ele. Esse grau de desenvolvimento da vontade nós encontramos muito mais raramente. Nessa condição, a vontade obriga a razão a pensar, e pensar só naquilo que é razoável). Nessa situação da alma: o corpo, os sentimentos e a razão deixam de existir autonomamente, existe só a vontade dotada das capacidades corporal, afetiva e racional do homem; nessa situação, o espírito do homem se eleva ao grau superior do seu desenvolvimento e afasta-se por completo de tudo o material e sensorial. Nessa situação da alma a razão pensa só porque a vontade quer que ela pense, e pensa sobre isso, e não sobre outra coisa, justo porque a vontade escolheu esse objeto de reflexão e não outro. Nesse grau de desenvolvimento da vontade nada tem influência. Para desenvolver a vontade em geral e atingir o mais alto grau do seu desenvolvimento é necessário passar também pelo grau mais baixo. De acordo com essa divisão da vontade, divido também as regras morais, cujo objeto é desenvolver a vontade, em três partes: 1) regras para o desenvolvimento da vontade corporal, 2) regras para o desenvolvimento da vontade afetiva, 3) regras para o desenvolvimento da vontade racional.

\section{Regras para o desenvolvimento da vontade corporal}

Regra geral: todas as atividades devem ser determinações da vontade e não a satisfação involuntária das necessidades corporais. E como já dissemos que os sentimentos e a razão têm influência sobre a vontade corporal, então essas duas capacidades devem determinar as regras, de acordo com as quais poderia agir a vontade corporal para o seu 
próprio desenvolvimento. Os sentimentos dão-lhe direção e indicam o seu objetivo; já a razão dá os meios pelos quais a vontade corporal pode atingir esse objetivo.

Regra 1) Cada manhã, estabelecer o que deves fazer durante o dia inteiro e cumprir com tudo o estabelecido, mesmo naquelas situações em que o cumprimento do estabelecido te traga algum prejuízo. Além do desenvolvimento da vontade, esta regra desenvolve também a razão que determinará ponderadamente as atividades da vontade. Regra 2) Dorme o menos possível (o sono é, na minha opinião, o estado do homem em que a vontade está absolutamente ausente). Regra 3) Suporta todo e qualquer mal-estar corporal sem manifestálo externamente. 4) Honra a tua palavra. 5) Se começares uma atividade, qualquer que seja, não a abandones enquanto não tiveres terminado. 6) Tem sempre uma tabela, em que estejam determinadas as mínimas circunstâncias da tua vida, até quantas vezes fumar cachimbo ao dia. 7) Se fazes alguma coisa, então emprega todas as tuas capacidades corporais naquilo que fazes. Já se muda teu estilo de vida, então muda também essas regras.

\section{Regras para o desenvolvimento da vontade afetiva ${ }^{31}$}

(Os próprios sentimentos traçam para si um objetivo)

A fonte de todos os sentimentos é o amor em geral, que se divide em duas espécies de amor: o amor a si próprio ou amor-próprio e o amor a tudo o que nos circunda. (Não reconheço o amor a Deus, porque não devemos chamar com o mesmo nome o sentimento que temos pelos seres semelhantes ou inferiores a nós e o sentimento que temos pelo ser supremo, não limitado nem no espaço, nem no tempo, nem em força e que é inconcebível). Esses dois sentimentos básicos agem mutuamente um sobre o outro. Regra geral: Todos os atos sensíveis devem ser não o cumprimento inconsciente das necessidades do sentimento, mas a determinação da vontade. Todos os sentimentos que têm como fonte o amor a todo o mundo, são bons; Todos os sentimentos que têm como fonte o amor-próprio são maus. Examinemos cada categoria de sentimentos em separado. Que sentimentos provêm do amor-próprio? 1) ambição de glória. 2) Cobiça 3) amor (entre homem e mulher).

Agora, vejamos quais devem ser as regras para o predomínio da vontade sobre cada um desses sentimentos.

\footnotetext{
${ }^{31}$ Estas regras foram redigidas por Tolstói entre março e maio de 1847 e foram anotadas por ele em um caderno separado.
} 


\section{Regras para a subordinação do sentimento de amor-próprio à vontade}

Regra 8) Não te preocupes com a aprovação das pessoas que não conheças ou que desprezes. Regra 9) Preocupa-te mais contigo do que com a opinião dos outros. 10) Sê bom e faze tudo para que ninguém saiba que és bom. (A ambição de glória costuma ser útil para os outros, mas não para si mesmo). 11) Busca sempre nas outras pessoas o lado bom e não o mau. Dize sempre a verdade. Se, agindo para ti, os teus atos te parecem estranhos, não justifiques tuas ações diante de ninguém. A estas regras para a subordinação dos sentimentos à vontade é necessário acrescentar ainda a seguinte: 12) Nunca deixes teus sentimentos transparecerem.

\section{Regras para a subordinação do sentimento de avareza à vontade}

Regra 13) Vive sempre pior do que poderias viver. 14) Não mudes o teu estilo de vida, nem que fiques dez vezes mais rico. 15) Usa todo o incremento de tua propriedade, não para ti, mas para a sociedade.

Regras para a submissão do sentimento de amor à vontade

Regra $1^{\text {ra }}$. Afasta-te das mulheres. $2^{\text {da }}$. Mata a tua luxúria com trabalho.

Os sentimentos provenientes do amor são: 1) Amor a tudo o que existe. 2) Amor à pátria. 3) Amor pelos conhecidos.

\section{Regras para a submissão do sentimento de amor universal à vontade}

Regra 16. Sacrifica todos os demais sentimentos de amor ao amor universal. (Então, a vontade exigirá somente a satisfação das exigências do amor universal e predominará sobre ele. Regra 17) Doa a décima parte de tudo aquilo de que puderes dispor, para o bem dos outros).

Ama a ti mesmo do mesmo modo que aos outros e ajuda mais àqueles que são mais infelizes que tu e aos quais seja mais fácil ajudar.

Regras para a submissão dos sentimentos de amor à pátria, e amor pelos conhecidos à vontade

18) Todos esses sentimentos se submetem uns aos outros na mesma ordem em que estão aqui. 


\section{Regras para o desenvolvimento da vontade intelectual}

Regra 19) Determina desde o começo do dia todas as tuas ocupações intelectuais. 20) Quando te ocupares de alguma coisa, esforça-te para que todas as tuas capacidades mentais estejam dirigidas a esse objeto. 21) Para que nada externo, corporal ou afetivo influencie o rumo do teu pensamento, mas para que o pensamento se auto-determine (sic) ${ }^{32}$. 22) Para que nenhuma vontade, nem corporal nem afetiva, tenha influência sobre a razão $(\text { sic })^{33}$.

Qualquer que seja a tarefa intelectual que tiveres começado, não a abandones enquanto não a tiveres terminado. Como essa regra pode levar a um grande abuso, então é necessário restringi-la com a seguinte regra: Tem um objetivo para toda a vida, um objetivo para uma determinada época da tua vida, um objetivo para um determinando momento, um objetivo para um ano, para um mês, para uma semana, para um dia, para uma hora e para um minuto, sacrificando o objetivo mais baixo pelo mais elevado.

\section{Regras para o desenvolvimento da memória}

Regra 23) Faz um resumo de tudo o que estudares e decora-o. 24) Todo dia, estuda versos naquela língua que souberes mal. 25) Repete à noite tudo o que aprendeste durante o dia. Cada semana, cada mês e cada ano, faz um teste de tudo o que estudaste e se achares que esqueceste, então começa desde o início.

\section{Regras para o desenvolvimento da atividade}

A atividade costuma ser de três gêneros: atividade corporal, afetiva e intelectual. Em conformidade com isso, também as regras para o desenvolvimento da atividade dividem-se em regras para o desenvolvimento da atividade corporal, afetiva e intelectual.

a) Regras para o desenvolvimento da atividade corporal

Regra 26) Inventa para ti a maior quantidade possível de ocupações. 27) Não tenhas criados. 28) Não exijas ajudantes para fazer o que puderes terminar sozinho.

\section{Regras para o desenvolvimento da atividade afetiva}

Como já foi dito, todos os sentimentos provenientes do amor-próprio são maus; então, por conseguinte, aqui devemos apenas estabelecer regras pelas quais possa desenvolver-se a atividade dos sentimentos provenientes do amor em geral. Regra 29) referente ao amor em geral. Que, todos os dias, o teu amor a todo o gênero humano se

\footnotetext{
${ }^{32}$ A frase está incompleta no original. Supõe-se que as regras 21 e 22 sejam continuação da regra 20. (N. de T.) ${ }^{33}$ Idem.
} 
expresse de alguma maneira. Regra 30) Referente ao amor à pátria. Sê útil à pátria tanto quanto puderes. Regra 31) Referente ao amor pelos conhecidos. Esforça-te por encontrar o maior número de pessoas a quem possas amar mais do que a todas as pessoas próximas. 32) Referentes ao amor pelos parentes.

\section{Regras para o desenvolvimento da atividade intelectual}

Regra 32) (sic) ${ }^{34}$ Não faças châteaux en Espagne ${ }^{35}$. 33) Esforça-te em dar a maior quantidade possível de alimento ao intelecto.

\section{Regras para o desenvolvimento das capacidades intelectuais}

Temos 5 capacidades intelectuais principais - a capacidade de representar, a capacidade de memorizar, a capacidade de comparar, a capacidade de concluir a partir dessas comparações e, por fim, a capacidade de organizar essas conclusões.

\section{Regras para o desenvolvimento da capacidade de representar}

34) São muito úteis para o desenvolvimento dessa capacidade todos os jogos que exigem reflexão.

Sobre as regras para o desenvolvimento da capacidade de memorizar já falei.

\section{Regras para o desenvolvimento da capacidade de comparar}

35) Estuda bem aqueles objetos que fores comparar. 36) Compara toda ideia nova que encontrares com as já conhecidas. Justifica todas as ideias abstratas com exemplos.

\section{Regras para o desenvolvimento da capacidade de concluir}

36) (sic) ${ }^{36}$ Estuda matemática. 37) Estuda filosofia. 38) Lê toda obra filosófica fazendo observações críticas.

\section{Regras para o desenvolvimento da capacidade de organizar as conclusões}

39) Estuda o sistema de tua própria existência. 40) Leva todas as tuas noções sobre qualquer ramo do conhecimento a uma conclusão geral. 41) Compara todas as conclusões entre si para que não se contradigam entre si. 42) Escreve uma composição, não superficial, mas erudita.

\footnotetext{
${ }^{34}$ Numeração repetida no original. (N. de T.)

${ }^{35}$ Em francês no original. A expressão francesa Faire, bâtir châteaux en Espagne é equivalente à portuguesa "construir castelos no ar" (N. de T.).

${ }^{36}$ Numeração repetida no original. (N. de T.)
} 
Regras para o desenvolvimento dos sentimentos elevados

e o aniquilamento dos sentimentos baixos ou dito de outra maneira:

regras para o desenvolvimento do sentimento de amor

e o aniquilamento do sentimento de amor-próprio

Regra geral: quanto mais satisfizeres uma de tuas necessidades, tanto mais ela se intensificará, e quanto menos a satisfizeres, tanto menos ela agirá. 42) (sic) ${ }^{37}$ Amando todos igualmente, não te excluas desse amor. 43) Ama cada próximo do mesmo modo como a ti próprio, mas dois próximos mais do que a ti próprio.

\section{Regras para o desenvolvimento da ponderação}

Observa qualquer objeto por todos os lados. Em qualquer ato considera seu prejuízo e sua utilidade. No momento de qualquer ato, observa por quantos meios ele pode ser feito e qual deles é o melhor. Observa as causas de cada fenômeno e suas possíveis consequências.

\footnotetext{
${ }^{37}$ Numeração repetida no original. (N. de T.)
} 


\section{Caderno C}

1850

14 de junho de 1850. [Iásnaia Poliana]. Mais uma vez retomei os diários e mais uma vez com novo zelo e novo objetivo. Quantas vezes já? Não me lembro. Não importa, talvez o largue de novo. Em compensação, é uma ocupação agradável e será agradável reler, como foi agradável reler os antigos. São tantos os pensamentos que vêm à cabeça e parecem notáveis; mas quando vamos ver, é tudo um vazio; Já outros são verdadeiramente aproveitáveis - para isso é que é necessário um diário. Pelo diário é muito cômodo julgar a si próprio.

E depois, como eu acho necessário definir todo o gênero de ocupações antecipadamente, também para isso é necessário um diário. Gostaria de acostumar-me a definir meu estilo de vida antecipadamente, não só para um dia, mas para um ano, para alguns anos, até para toda a vida. É difícil demais, quase impossível; contudo, tentarei, primeiro, por um dia, depois por dois; quantos dias eu for fiel ao determinado, tantos dias planejarei para o futuro. Por essas determinações subentendam-se não regras morais, independentes de tempo e lugar, que nunca mudam e que eu estabeleço com algum propósito, mas, precisamente, determinações temporais e locais: onde e quanto tempo ficar, quando e o que fazer.

Ocorrem casos em que tais determinações podem ser mudadas. Mas o único caso em que admito tal gênero de desvios é quando eles são definidos por regras. Por isso, no caso de desvios, eu explicarei as causas destes no diário.

Para 14 de junho. Das 9 às 10, nadar e passear, das 10 às 12, música. Das 6 às 8 , correspondências, das 8 às 10, a administração da propriedade e escritório.

Os últimos três anos, passados por mim tão desregradamente, às vezes me parecem muito interessantes, poéticos e, em parte, úteis; vou esforçar-me por recordá-los e registrá-los com mais franqueza e em mais pormenores. Eis ainda uma terceira finalidade do diário.

15 de junho. Ontem cumpri exatamente tudo o prescrito. Para dia 15 de junho. Das 4 $1 / 2$ às 6 no campo, administração da propriedade e nadar. Das 6 às 8 , continuar o diário, Das 8 às 10 , escrever um método de música. Das 10 às 12 , tocar o piano. Das 12 às 6 , café-damanhã, descanso e almoço. Das 6 às 8 , leitura e regras, das 8 às 10, nadar e administração da propriedade. 
16 de junho. Ontem mal cumpri o prescrito. Por quê? Vou explicar depois. Para dia 16. Das $5 \frac{1}{2}$ às 7 , nadar e estar no campo. 7 - 10, diário, 10 - 12, tocar, 12 - 6, café-damanhã, descanso e almoço, 6 - 8, escrever sobre música. 8 - 10, administração da propriedade.

17 de junho. Levantei-me às 8 , até às 10 não fiz nada, das 10 às 12 li e diário, das 12 às 6 café-da-manhã, descanso, alguns pensamentos acerca de música e almoço, das 6 às 8 música e das 8 - 10 administração.

Segundo dia de preguiça. Não cumpro o que foi traçado. Por quê? Não entendo. Porém, não me desespero, vou forçar-me. Ontem, além de não ter cumprido o determinado, ainda infringi a minha regra. Agora, já não infringirei a regra de, na aldeia, não ter nenhuma mulher, exceto em algumas ocasiões que não buscarei, mas que também não deixarei passar.

Eu notei que quando estou em estado de apatia, qualquer texto filosófico me predispõe fortemente para a atividade. Agora leio Montesquieu. Parece-me que fiquei preguiçoso pelo fato de haver começado coisas demais; Por isso, de agora em diante, não passarei a outra coisa, enquanto não houver cumprido o que estiver traçado. Para que eu não possa pretextar que não consegui elaborar um sistema, incluirei no diário tanto as regras gerais como as regras do campo da música e da administração.

Das regras gerais. Não adies o que te propuseste fazer, sob o pretexto de distração ou diversão; Mas põe-te a trabalhar imediatamente, ainda que em aparência. As ideias virão. Por exemplo, se te propuseste escrever regras, então pega o caderno, senta-te à mesa e não te levantes enquanto não houveres começado e terminado.

Regras no campo da música: Tocar diariamente: 1) As 24 escalas, 2) todos os acordes, o arpejo em duas oitavas, 3) todas as inversões das tríades, 4) a gama cromática. Aprender uma peça e não ir adiante até não haver um lugar onde pares. transpor todas as cadenzas encontradas para todos os tons e aprendê-las. Diariamente, interpretar pelo menos 4 páginas de música e não avançar até não encontrar um verdadeiro doigté*.

No campo da administração da propriedade. Meditar cada ordem no que se refere a seu benefício e prejuízo. Examinar pessoalmente, todos os dias, cada parte do trabalho na propriedade. Não deixar-se levar pela precipitação no dar ordens, repreender e castigar, lembrar que na administração da propriedade, mas do que em qualquer outra coisa, é necessária paciência. Mudar qualquer ordem dada, ainda que ela se tenha revelado prejudicial, apenas a critério próprio e em caso de extrema necessidade.

\footnotetext{
* Disposição dos dedos.
} 
Anotações.

O inverno do terceiro ano que vivi em Moscou, passei-o de modo desordenado, sem serviço, sem ocupações, sem objetivos. E vivi assim não porque, como dizem e escrevem muitos, em Moscou todos vivam assim, mas, simplesmente, porque esse tipo de vida me agradava. Em parte, porque até a situação de um jovem no mundo moscovita, predispõe-no à preguiça. Eu digo: de um jovem que reúna em si certas condições a saber: instrução, bom nome e uns dez ou vinte mil de rendas. A vida de um jovem, que reúna tais condições, é a mais agradável e completamente despreocupada se ele não trabalha (isto é, a sério) mas simplesmente consta como funcionário e gosta de vadiar. Todos os salões estão-lhe abertos, tem direito de ter vistas sobre cada noiva. Não, não existe um único jovem que, na opinião geral do mundo, possa estar mais alto do que ele. Chegue este mesmo senhor a Petersburgo, e ele vai se atormentar com que S. e G. Gortchakov estiveram na corte e eu não; com como ir parar aos saraus da baronesa Z. e à recepção onde a condessa A. e assim por diante, e não o conseguirá; só entrará nesses salões se tiver o apóio de alguma condessa. E se ele não cresceu lá e não sabe suportar humilhações, tirar proveito de toda e qualquer oportunidade, ele até consegue penetrar, embora com dificuldade, mas então é sem honra.

18 de junho. Levantei-me às $71 / 2$, até as 11 , nada; $11-12$, música, $2-5$, administração, $6-8$, sobre a música, 8 -11, trabalho, música e leitura.

19 de junho. Ontem passei o dia bastante bem, cumpri quase tudo; só não estou satisfeito de uma coisa: não consigo afastar de mim a volúpia, tanto mais que essa paixão se confundiu em mim com o costume. Agora, tendo cumprido por dois dias, faço prescrições para dois dias: 19 de junho. 5 - 8 administração e ideias sobre música, 12 - 6, descanso, $6-8$ música, 8 - 10 administração da propriedade. 20 de junho. 5 - 10, administração da propriedade e diário, 10 - 12, música, 12 - 6, descanso, 6 - 10, administração da propriedade.

Das regras gerais. Às vezes acontece que te lembras de alguma coisa desagradável, e não pensas direito nessa coisa desagradável, e isso estraga teu humor por um bom tempo.

Examinar cada ideia desagradável: em primeiro lugar - será que ele pode ter consequências; se sim, então, como evitá-las. Se não for possível evitá-las, e se tal circunstância já tiver ficado para trás, então, depois de haver pensado direitinho, esforçar-se por esquecer ou acostumar-se a ela. 
8 de dezembro. $[\text { Moscou }]^{38}$ Passei cinco dias a escrever o meu diário e passei cinco meses sem tocá-lo. Esforçar-me-ei em lembrar-me do que fiz durante esse tempo e por que eu, aparentemente, estou tão atrasado em relação às atividades planejadas. Uma grande viragem aconteceu em mim durante este tempo. A tranqüila vida na aldeia, as antigas tolices e a necessidade de ocupar-me dos meus assuntos, trouxeram seu fruto. Deixei de construir castelos no ar e de traçar planos, para cujo cumprimento, não haveria forças humanas suficientes. Já o mais importante e favorável a essa mudança de convicções é que eu não tenho já esperanças de chegar ao que quer que seja com a minha razão e não desprezo já as formas aceitas por todas as pessoas. Antigamente, tudo o que era comum, parecia-me indigno de mim; porém agora, pelo contrário, eu não reconheço quase nenhuma convicção como boa e justa até não ver a sua aplicação e realização por muitos. Estranho, como pude eu menosprezar o que constitui a principal vantagem do homem - a capacidade de compreender as convicções dos outros e ver nos outros as materializações delas na prática. Como pude eu dar curso à minha razão, sem nenhum controle, sem nenhuma aplicação? Numa palavra, e a mais simples, eu criei juízo e envelheci.

Muito colaborou para tal mudança o meu amor-próprio. Havendo me entregue a uma vida desenfreada, notei que as pessoas que estavam abaixo de mim em tudo, nessa esfera estavam muito acima de mim; Isso me doeu, e eu me convenci de que isso não era a minha predestinação. Pode ser que para tal também tenham contribuído dois estímulos. Primeiro, a perda de dinheiro no jogo para Ogariov $^{39}$, (que conduziu meus assuntos para uma absoluta desordem) que me transtornou completamente a vida, tanto, que me pareceu não havia esperança de endireitá-la. E, depois disso, o incêndio ${ }^{40}$, que me forçou a agir contra a minha vontade. A revanche, por sua vez, deu cor mais alegre a essas ações. Só me parece que me tornei já frio demais. Apenas vez ou outra, em especial quando me deito, sobrevêm minutos em que o sentimento quer sair. A mesma coisa nos minutos de bebedeira. Mas eu me prometera não me embebedar. Não continuarei agora com as minhas anotações porque estou ocupado com coisas em Moscou; se tiver tempo livre, escreverei uma novela da vida cigana ${ }^{41}$. Notei ainda uma mudança importante vizinho: tornei-me mais seguro de mim, isto é, deixei de perturbar-me. Eu suponho que isso decorre do fato de que eu tenho um objetivo em vista

\footnotetext{
${ }^{38}$ Tolstói encontrava-se em Moscou desde 5 de dezembro de 1850.

${ }^{39}$ Vladímir Ogariov, filho de um vizinho proprietário de terras.

${ }^{40} \mathrm{O}$ incêndio na aldeia de Iásnaia Poliana aconteceu em outubro do ano 1850.

41 O trabalho sobre a "novela da vida cigana" menciona-se nas anotações seguintes, inclusive até 29 de Dezembro de 1850. A novela não foi concluída o e seu conteúdo é desconhecido. Os manuscritos não se conservaram.
} 
(interesse), e, perseguindo-o, eu podia avaliar-me e adquirira consciência da minha dignidade, o que facilita tanto as relações entre pessoas.

\section{Regras para o jogo em Moscou até 1 de janeiro}

1) O dinheiro que eu tiver no bolso, posso arriscá-lo por uma por várias noites. 2) Jogar só com pessoas que tenham mais do que eu. 3) Jogar sozinho e não se conter. 4) A soma que eu puser para perder, considerá-la um ganho quando for superior à outra em três vezes, isto é, se eu tiver colocado para perder 100, e ganhei 300, então, considerar 100 como ganho e não dá-los em revanche. Já se tiver a sorte de ganhar mais, então considerar como ganho também aquela soma que tinha a intenção de perder, só quando ganhar três vezes mais, e assim infinitamente. No que se refere às sessões de jogo, levar a seguinte conta: se obtive um ganho, calculá-lo nas perdas, se ganhar o dobro, então usar essa soma duas vezes e assim por diante. Se depois de um ganho houver uma perda, então subtrair a soma perdida, e o restante do último ganho dividi-lo em duas vezes; o seguinte ganho, dividi-lo em três. Para começar o jogo, dividir a soma reservada em quaisquer partes iguais. Eu, agora, dividi 300 rublos de prata em três.

Observação: como é claro, considerar uma sessão quando tu mesmo terminares e perderes ou ganhares o que tiver sido determinado. Em qualquer sessão lembrar tudo o escrito e não esquecê-lo. Por isso, não passar de uma sessão a outra sem calcular no tempo livre. Posso mudar estas regras, quando conseguir mais experiência. Mas até não escrever novas, deverei seguir estas. Depois de refletir, poderei fazer exceção a essas regras, quando tiver ganho 9 mil rublos de prata e 29 [mil] rublos de prata.

Regras relacionadas com o próprio processo do jogo: Sempre, eu mesmo dar as cartas (...) Quando estiver ganhando, aumentar a aposta tanto como for possível. Sempre manter na cabeça um cálculo aproximado dos resultados do jogo. Regras para a sociedade. Escolher situações difíceis, esforça-se por sempre dominar a conversação, falar alto, serena e claramente, esforçar-me por eu próprio começar e eu próprio terminar a conversação. Procurar ter relações com pessoas de um círculo mais elevado que o meu. No que se refere a essas pessoas, preparar o tipo de trato que terei com elas antes de encontrá-las. Não esforçarse em falar diante de desconhecidos. Não mudar a conversa constantemente do francês para o russo e do russo para o francês. O principal é, primeiro, lembrar que deves forçar-te quando te encontrares naquele círculo no qual tens dificuldades. No baile, convidar para dançar as mulheres mais importantes. Se ficar aturdido, não perder-me e continuar. Ser tão frio como possível e não expressar nenhuma impressão. 
Tarefas para o dia de hoje. 11. ficar em casa, ler, à noite escrever regras para a sociedade e um resumo da novela. Tarefas para dia 8 de Dezembro. Ler desde cedo, depois, diário até o almoço e horário para os assuntos e visitas de domingo. Depois do almoço, ler e banho, à noite, se não estiver muito cansado, novela. Pela manhã, imediatamente depois do café, cartas para o escritório, para a titia e para Perfíliev.

[13 de dezembro] 12 de dezembro, apesar de não ter escrito o diário, passei o dia bem, isto é, não na ociosidade. Fui ver as autoridades e ao clube, como consequência do qual me convenci: primeiro, que na tendência atual da sociedade vou prosperar; e que, parece-me, vou deixar de jogar definitivamente. Parece-me que já não tenho paixão pelo jogo, mas não o afirmo. É necessário experimentar na realidade. Não buscarei ocasiões, mas não deixarei passar uma vantajosa. Ocupações para dia 13 de dez. Falar com Petr sobre a solicitação para o Czar e sobre se posso ou não ser transferido em serviço a Moscou. Escrever cartas para a titia, Perfíliev, ir ver o Príncipe Serguei Dmítrievitch e Kriukov, ler, fazer compras (camélias) e o livro sobre música, almoçar, ler e ocupar-me com a composição de música ou da novela.

14 de Dezembro. Estou insatisfeito comigo pelo dia de ontem. Primeiro, por ter escutado todas as injúrias da condessa contra Vássinka, de quem eu gosto e segundo, pela estúpida delicadeza de ontem perdi a noite inteira. É necessário escrever hoje um bilhete de desculpas, ir ver Vássinka, almoçar em casa de Gortchakov e à noite fazer alguma coisa desde o começo; o mais importante é escrever as cartas.

15 de Dezembro. Estou muito insatisfeito com o dia de ontem. Primeiro porque não fiz nada tocante ao conselho tutelar; segundo, porque não escrevi nada e terceiro, porque comecei a fraquejar e entregar-me à influência das pessoas. Levantar-me muito cedo, ler desde manhãzinha, depois dedicar-me ao diário, escrita e cartas, às 12 horas ir para o conselho, ir ter com Evréinov, Kriúkov, Aníkeva e Lvov; Almoçar em casa e escrever mais um pouco; depois ir ao teatro e, de novo, trabalhar em casa.

Regras para a Sociedade. Não mudar as denominações e sempre chamar as coisas de uma única maneira.

Não deixar passar nem a menor coisa desagradável ou mordacidade a ninguém sem pagar na mesma moeda em dobro. 
16 de dezembro. Cumpri tudo com exceção da escrita. Sempre levantar-se cedo. Escrever desde cedo as cartas e a novela, ir para o Kalymajni Dvor ${ }^{42}$, e aos banhos, enviar ao conselho e a Lvov, almoçar em casa e, à tarde, ir à casa do príncipe Andriéi Ivánovitch, jogar e fazer a corte à princesa. Comprar feltro e partituras depois do almoço.

17 de Dezembro. Levantar-se cedo e ocupar-me da carta para Diakov e da novela e, às 10 horas, ir para a missa no mosteiro de Zatchatiévski, para a casa de Anna Petrovna e Yakovleva. Daí passar por casa de Kolóchin, enviar pelas partituras, preparar a carta para o escritório, almoçar em casa, dedicar-me à música às regras e à noite ir às mulheres e ao clube. No dia 18, estar no conselho, e em casa de Lvov, de Evréinov, do príncipe Andriéi Ivánovitch e solicitar uma colocação.

Regras gerais. Deitar-se, quando nada necessário o impedir, às 12 horas e levantar-se às 8 . Todo dia, praticar música seriamente por 4 horas.

18 de dezembro. Levantar-se às 9 1/2, até $10 \frac{1}{2}$ ler, até 12 escrever e receber Volkónski, das 12 às 2 perambular, escrever e escrever até a noite. Almoçar em casa.

19 de dezembro. Cumpri com o prescrito para dia 18.

20 de dezembro. Ir às 10 para casa de Volkónski, das 11 às duas, cartas e novela. Até as $3 \frac{1}{2}$, música, até as 9 estar em casa dos Diakov, em casa escrever sobre música. São já às 11 da noite e não escrevi nada e estou insatisfeito comigo por ter me perturbado em casa dos Diakov.

21 de dezembro. Das 8 às 10 escrever, das 10 às 2 arrumar dinheiro e fazer esgrima. Das 2 às 6, almoçar em algum lugar, das 6 até lá pelas 11 da noite, escrever em casa e não receber ninguém. Em casa de Lvov, saber do trabalho de Serioja. Ir para a casa da condessa Avdótia Maksímovna.

Não ler romances.

\footnotetext{
${ }^{42}$ Pátio das Carruagens. Lugar onde se guardavam as carruagens do czar, situado na Kolymájnaia úlitsa (rua das Carruagens). (N. de T.).
} 
22 de dezembro. Até as 12 escrever sobre música e analisar, ir para a casa da condessa e almoçar. Se não receber dinheiro, escrever para Libin e Piotr Evstratov. Escrever a primeira carta.

24 de dezembro. Levantar-se às 12, escrever cartas para o escritório. Pedir que enviem a conta. Almoçar em casa com Láptevy, antes do almoço, ir ver as relíquias, à noite estudar o General baixo e a sonata, se tiver ânimo, escrever a $1^{\text {ra }}$ carta. Regras. Jogar às cartas só em casos extremos. Contar o menos possível sobre si. Falar alto e com clareza. Regras. Fazer exercício todos os dias. De acordo com a lei religiosa, não ter mulheres.

25 de dezembro. Ir ver o príncipe Serguei Dmítrievitch, Yákovleva, os Zakriévski, o príncipe Andriéi Ivánovitch, a condessa, Perfíleva, Volkónski e os Diakov. Enviar fotografias a Gortchakov, Lvov, Óuzerov, Kolóchin, Volkónski.

26 de dezembro. Perdi o meu tempo, estive com ciganos.

27 de dezembro. Levantar-se às 9, até as 12 ir para Kalymajny Dvor e para a casa de Tchortov e de Anna Petrovna. Em casa, se tiver dinheiro, chamar para almoçar os 2 Volkónski, Ózerov e Sologub. Estar com os ciganos. Até o almoço, depois da preparação, ir para casa de Gautier e de Tchulkov.

28 de dezembro. Estou muito insatisfeito comigo. Principalmente porque não estive bem de saúde; agora seguir esta regra: se estiver doente, então é permitido não cumprir o planejado, mas também não fazer outra coisa. Ir ver os Gortchakov, reler o diário e fazer o que não cumprido. Em Neskutchnaia, ir e arrastar a asa à princesa. À noitinha, ir ver os Ciganos com Nikolai Gortchakov e pernoitar.

29. Vivo, por completo, como o gado; embora não completamente à toa, abandonei quase todas as minhas ocupações e no espiritual tenho caído muito. Levantar-me cedo e não receber ninguém nem ir a lugar nenhum antes das 2 horas; às 2 ir ver Tchulkov, os Diakov e almoçar. Falar com o Príncipe e pedir uma vaga. Na vastidão, refletir sobre as ações futuras em qualquer novo emprego. Pela manhã, escrever a novela, ler e jogar ou escrever sobre música; à noite, as regras ou ir ver os ciganos. 
30 de dezembro. Procurar uma situação difícil. Levantar-me cedo. Fazer a bagagem, preparar tudo, inserir no diário a minha estada e Moscou, pedir a Kolóchin que procure saber sobre o emprego e às 3 partir.

[31? de dezembro. Pokróvskoe] Dia 31 de dezembro estive na estrada. Encontrei-me com Scherbátov e resolvi ficar na estação de posta; estive com o chefe de posta mas não conversei suficientemente a fundo com Scherbátov. 
1 de janeiro. Iásnaia Poliana. 1 de janeiro de 1851. Estive em Pokrovskoe. Vi Nikólenka ${ }^{43}$. Ele não mudou, já eu, mudei muito e poderia influenciá-lo, se ele não fosse tão estranho; ele, ou não nota nada e não gosta de mim, ou esforça-se por fazer de conta que não nota e que não gosta.

2 de janeiro. Passar o dia do batismo ${ }^{44}$ com os meus, ir à casa dos Diakov e, à noite, ir a Tula. Estabelecer ali com os Scherbátov as condições e regressar a Iásnaia na noite do dia 3, ficar até o anoitecer e na noite do dia 4 ir para Moscou. Em Tula, deixar uma procuração e um requerimento, ir ter com o presidente.

12 de janeiro. Moscou. Levantar-me às 8 , ir para Iviérskaia, reler tudo o relativo a essa estação, pensar bem em tudo, tomar notas e ir ver Tatíschev.

13 de janeiro. Desocupei o quarto da estação. O caráter não resistiu. As carroças chegaram $^{45}$. Deixei ir Nikolai. Comportei-me mal.

Regra: fazer cópia de todas as cartas e tê-las comigo em ordem.

14 de janeiro. Remorsos. Quase não tenho dinheiro. Procurar Serguéi Dmítrievitch Gortchakov, os Kolóchin.

17 de janeiro. 1851. Desde o dia 14 tenho me comportado insatisfatoriamente. Não fui ao baile dos Stolypin; Emprestei dinheiro e, por isso, agora estou sem um tostão ${ }^{46}$. E tudo isso porque fraquejei de caráter. Regra: Não jogar ao eralash $^{47}$ por menos de 25 copeques de prata a parada. Não tenho dinheiro em absoluto; O prazo de pagamento de muitas letras de câmbio já expirou; Também começo eu a notar que, sob nenhum aspecto, minha estada em Moscou me traz proveito e gasto muito acima das minhas rendas.

\footnotetext{
${ }^{43}$ S. N.N. Tolstói quem chegara do exército para passar férias em fins de Novembro de 1850.

${ }^{44}$ Batismo de Nikolái, filho de M. N. Tolstói.

${ }^{45}$ Comboio de carroças com víveres proveniente de Iásnaia Poliana.

${ }^{46}$ No original russo, Tolstói escreveu “estou sem um grosh”. Na Rússia, o grosh foi, até 1917, uma moeda com valor equivalente a meio copeque (N. de T.).

${ }^{47}$ Antigo jogo de cartas (N. de T.).
} 
Regra: chamar as coisas pelos seus nomes. As pessoas que falam de modo superficial de assuntos pecuniários, ocultar a situação dos meus negócios e, pelo contrário, esforçar-me por interrompê-las e levar a conversa para tal matéria.

Dos três meios que se me apresentaram de endireitar os meus negócios, deixei escapar quase todos, precisamente: 1) Entrar num círculo de jogadores e, tendo dinheiro, jogar. 2) Entrar nas altas esferas e, nas condições sabidas, casar-me. 3) Achar uma vaga vantajosa para o serviço. Agora, apresenta-se ainda um quarto meio, a saber: pedir dinheiro a Kiriévski. Não há conflito entre essas quatro coisas e é necessário agir. Escrever à aldeia para que enviem depressa 150 rublos de prata, ir ver Ózerov e oferecer o cavalo, e ainda publicar um anúncio nos jornais. Ir ver a condessa e esperar, procurar saber dos convites para o baile dos Zakriévski, encomendar uma casaca nova. Antes do baile, pensar muito e escrever. Ir ver o príncipe Serguéi Dmítrievitch e falar do emprego, com o príncipe Andriéi Ivánovitch e pedir um lugar. Penhorar o relógio.

Saber do Evriéinov onde mora Kiriévski e ir à sua casa. À 1 1/2 ir à casa Evriéinov e, dali, qualquer que for a resposta, ir ter com Nikolai Vasílievitch.

18 [janeiro] Não me comportei nem bem nem mal. Pouca firmeza. No dia 19 - a colocação. Ocupações: estar no picadeiro, visitar Tchertova, os Gortchakov, o príncipe Nikolai Mikháilovitch. À noite, banca de jogo. Escrever a historia da minha infância.

25 de janeiro. Apaixonei-me ou imaginei que me apaixonara. Estive em uma pequena festa e perdi o tino. Comprei um cavalo de que não precisava em absoluto. Regras: Não oferecer nenhum preço por uma coisa não necessária. Assim que entrar num baile, convidar imediatamente um par e dançar uma valsa ou polca inteira. Hoje à noite, pensar nos meios de endireitar as coisas. Ficar em casa.

28 de fevereiro. Perdi muito tempo. Primeiro, entreguei-me aos prazeres mundanos; depois, novamente, a minha alma foi tomada pela sensação de vazio. Estou atrasado no cumprimento das tarefas, isto é, das tarefas que têm como objeto a minha própria pessoa. Atormentou-me durante muito tempo o fato de eu não ter nenhum pensamento ou sentimento arraigado na alma que determinasse todo o rumo da vida - é tudo como der e vier, agora, parece-me que encontrei uma tal ideia e um objetivo permanente: o desenvolvimento da vontade, objetivo que já há muito tempo persigo, mas do qual apenas agora tomei consciência não simplesmente como uma ideia, mas como uma ideia enraizada na minha alma. 
Programa do dia de amanhã. Levantar-me às 9 horas. Estudar a enciclopédia ${ }^{48}$ e escrever um resumo. Ir ao funeral, depois ir fazer ginástica, almoçar e, das 6 às 12 estudar sozinho ou com Kolóchin. Não fumar. Lembrar-me sempre de que o cumprimento do programa estabelecido constitui toda a felicidade da minha vida e vice-versa.

1 de março. Regra: nas situações difíceis, agir sempre pela primeira impressão. Levantar-me às $8 \frac{1}{2}$, estudar até as12. Das 12 à 1 , música, da 1 às 2 , lições, das $2 \frac{1}{2}$ às 6 , descanso. Não ir atrás dos conhecidos. À noite em casa, lições.

2 de março. Comecei a fraquejar um pouco, sobretudo, porque que começara a parecer-me que por mais que eu trabalhasse sobre mim, de mim não sairia nada. Essa mesma ideia me veio porque eu estava ocupado exclusivamente com a força de vontade, sem pensar na forma como ela se manifestava. Vou esforçar-me em corrigir esse erro. Agora, quero preparar-me para o exame final da faculdade. Em consequência, eis a forma como deve manifestar-se a força de vontade. Mas não basta pegar no caderno e ler; é necessário prepararse para isso, é necessário estudar sistematicamente; é necessário conseguir as Questões de todas as disciplinas e fazer resumos delas ${ }^{49}$. É necessário arranjar um estudante que possa dar orientações e explicações.

Amanhã de manhã, ler a "Enciclopédia", desde o começo, com as notas de Nevôlin, das 8 horas às 12; Às 12 ir procurar o tal estudante; Às 2, ir fazer ginástica; Das 6 até lá pela meianoite, estudar a "Enciclopédia" ou outra coisa qualquer, e uma hora para a música. Regra. Lembrar que, em todo e qualquer cometimento, a primeira e única condição da qual depende o êxito é a paciência e que o que, mais do que qualquer outra coisa, atrapalha toda e qualquer empresa e muito prejudicou, especialmente a mim, é a pressa.

3 de março. Das 8 à $1 \frac{1}{2}$, enciclopédia, da $1 \frac{1}{2}$ às 4 , picadeiro, almoçar em casa do príncipe Andriéi Ivánovitch. À noite, trabalhar.

7 de março. 3, 4, 5, 6- não escrevi o diário.

Encontro para o diário, além do estabelecimento das atividades futuras, um objetivo útil: um balanço de cada dia da perspectiva das fraquezas de que queremos corrigir-nos.

\footnotetext{
${ }^{48}$ Tolstói chama enciclopédia o manuscrito do curso sobre a Enciclopédia de Direito ministrado na Universidade de Kazan pelo Professor A. G. Stanislavski.

${ }^{49}$ Como regra, as provas na faculdade são orais. Os estudantes recebem o questionário com antecedência e devem preparar as respostas (N. de T.).
} 
Hoje. De manhã, demorei para decidir-me a levantar, fui preguiçoso, de uma forma ou outra, enganando-me. Lia romances, quando tinha outra coisa por fazer; dizia comigo: é necessário beber café, como se fosse impossível fazer outra coisa enquanto se bebe café. $\mathrm{Na}$ companhia de Kolóchin, não chamo as coisas pelo nome; Embora ambos sintamos que a preparação para o exame é uma bobagem, eu não lhe expressei isto claramente. Recebi o Poiret com demasiada familiaridade deixei que algumas coisas me influenciassem: o fato de não conhecê-lo, a presença do Kolóchin e os modos inoportunos de grand-signeur. Fiz ginástica às pressas. Em casa de Gortchakov bati tão fininho que não fui atendido por Fausse Honte $^{50}$. Na casa dos Kolochin, saí da sala de modo muito feio; estava com pressa demais e quis dizer qualquer coisa muito amável. Não saiu. No picadeiro, acabei por entregar-me ao mauvaise humeur ${ }^{51}$ e, a causa de uma grã senhora, esqueci-me do meu afazer ali.

Em casa de Beguítchev eu quis exibir-me e, para a minha vergonha, quis imitar Gortchakov. Fausse honte. A Ukhtomski não lembrei o dinheiro. Em casa, atirava-me do piano a um livro e do livro ao cachimbo e à comida. Não pensei nos mujiques. Não me lembro, terei mentido? Provavelmente. Não fui à casa dos Perfilev e do Panin por irreflexão. Todos os erros do dia de hoje podem atribuir-se aos seguintes hábitos:

1) Indecisão, falta de energia. 2) Engano de mim próprio, isto é, pressentindo algo mau numa coisa, não paro para pensar nela. 3) Precipitação). 4) Fausse honte, isto é, aquele temor de fazer algo indecente que nos vem de uma visão unilateral das coisas. 5) Má disposição de espírito proveniente, na sua maior parte, 1, da precipitação, e 2, de uma visão superficial das coisas. 6) Incoerência, isto é, tendência a esquecer os objetivos próximos e úteis para aparentar algo. 7) Imitação. 8) Inconstância. 9) Irreflexão.

Tarefas para amanhã: das 8 às 9 cartas para a titia e Nikólenka sobre a venda, para Zagriájski, ao escritório sobre o dinheiro e a repartição. Das 9 às $1^{\circ}$, ginástica, das 10 às 11 , música - as escalas, valsa e adágio. Das 11 à 1 , Poiret. Da 1 às $2 \frac{1}{2}$ para a coudelaria, ir ver Volkónski, Lvov e Gortchakov. Ginástica, almoço, romance, convidados e diário.

8 de março. De novo, não me recobrei por muito tempo, porém, superei-o. Escrevi uma carta a Nikólenka (irreflexiva e precipitadamente). Para o escritório, escrevi da mesma forma tola adotada por mim (auto-engano). Não fiz bem a ginástica, isto é, demasiado pouco, de acordo com as minhas forças. Chamo esta fraqueza de arrogância, desvio da realidade. Olhei-me ao espelho muitas vezes. Esse estúpido amor-próprio físico do qual, além de algo

\footnotetext{
${ }^{50}$ Em francês no original. Falsa vergonha.

${ }^{51}$ Em francês no original. Mal-humor.
} 
ruim e ridículo, não pode sair nada. Com Poiret, de novo me perturbei (auto-engano). $\mathrm{Na}$ coudelaria agi com fraqueza [?], primeiro cumprimentei Golitsyn e não fui diretamente aonde devia. Distração. Na ginástica, gabei-me (auto-elogio). Quis dar a Kobylin uma verdadeira opinião sobre mim (vaidade mesquinha). Comi demasiadamente durante almoço (glutonaria). Fui ver Volkónski sem ter terminado minhas ocupações (falta de coerência). Empanturrei-me de doces, fiquei sem fazer nada. Menti. Tarefas para o dia 9. Das $8-10$, conta das divididas. Cartas: para a titia e Ferzen. 10 às 11, ginástica. Música das 11 às 12 . Sobre o dinheiro. Almoçar em casa de Gortchakov, sobre a vaga. Em casa, ler e escrever o que me vier à cabeça, resumo do lido ou até fazer anotações. Redigir um journal para as debilidades (de Franklin ${ }^{52}$ ).

9 de março. Fiquei muito tempo na cama (falta de energia). Carta a Islávin (desatenção). Fui embora de luvas ruins e sem chuba ${ }^{53}$ (irreflexão e apressuramento). Contei a Panin sobre a minha construção (desejo de exibir-se). Com Olivier e Beer (indecisão e covardia). Em casa dos Gortchakov (falsa vergonha e desejo de exibir-se). Fui ver Kirieévskaia (leviandade) simplesmente (covardia). Tarefas para dia 10. Levantar-se às 8. Das 8 às 9 , cartas, das 9 às 11 , música, 11 à 1 , esgrima. 1 - 1 1/2, os Anikieév e passear, ginástica, almoçar em casa de Lvov. À noite, ler e diário.

10 de março. Fiquei muito tempo na cama. Falei mal com Ózerov e convenci-o de comprar o cavalo. Baixeza. Poiret. Engano e precipitação. Menti a Beguítchev, dizendo que conheço os Gortchakov do Norte. Não peguei a chuba, precipitação e leviandade. No conselho, covardia. Na ginástica, vaidade. Em casa de Lvov presunção e afeitação. Não fiz as cópias, preguiça. Escrevo o Jornal às pressas e sem exatidão. Tarefas para dia 11 de março. Disposições em relação à malha e aos cavalos, diário, Jornal de Franklin e escrever até as 10, das 10 às 11, ginástica, das 11 às 12, música. Passear e almoçar até as 6. A partir das 6, anotações e ler.

12 de março. Passei o dia inteiro mal, mal e mal. Amanhã explicarei. Tudo porque ontem me deitara às 3 horas e veio o Zubkov. Atividades. Das 8 às 9, o diário, das 9 às 10 , ginástica, das 10 às 12 ler e anotações. Das 12 às 2, Beer, Muromtsev e os Diakov. Das 2 às 4,

\footnotetext{
${ }^{52}$ Conforme o modelo do diário do cientista americano Benjamin Franklin, Tolstói começou a levar seu diário, no qual anotou seus "pecados" e desvios das regras, com o intuito da auto-educação diária. Provavelmente, Tolstói soube do diário de Franklin por meio do romance de Dimitri Nikititch Begitchev A família Kholmski, que começou a ler em março.

${ }^{53}$ Agasalho russo tradicional feito de pele de ovelha, raposa ou visão.
} 
ginástica, almoço, das 6 às 10, ler e escrever ${ }^{54}$ ou Zubkov. Ontem. Passei o dia angustiado / mal-estar. 1) por não haver dormido o necessário, 2) do desarranjo de estômago. Quando chegarei eu a ser consciente das minhas forças, isto é, saber de antemão o que co seguirei suportar e o que não? Regra. Quando der vontade de fazer alguma coisa, tanto física, quanto moral, então, ponderar se a sua execução representa mais dificuldades do que benefícios; se não for assim, então pode-se passar à ação.

20 de março. As duas principais paixões que notei em mim são a paixão pelo jogo e a vaidade; Esta é tanto mais perigosa pelo fato de assumir uma quantidade inumerável de formas; tais como: desejo de exibir-se, irreflexão, distração e assim por diante. À noite reler o diário desde o dia de chegada a Moscou, fazer observações gerais e verificar as despesas e dívidas em Moscou.

Cheguei a Moscou com três objetivos. 1) Jogar. 2) Casar-me. 3) Conseguir um emprego. O primeiro é vil e baixo e eu, graças a Deus, depois de examinar a situação (o estado) dos meus negócios e renunciar aos preconceitos, resolvi endireitar os negócios e pôlos em ordem por meio da venda de parte da propriedade. O segundo, (graças a) em vista dos sensatos conselhos do meu irmão Nikólenka, fica adiado até o dia (momento) em que a isso me obrigar ou o amor ou a razão ou, inclusive o destino ao qual não se pode contrariar em tudo. O último não é possível antes de completar dois anos de serviço na província (gubernia); E a falar a verdade, embora eu queira isso, eu também quero muitas outras coisas incompatíveis. Por isso, esperarei que o próprio destino me coloque em tal situação.

Tive muitas fraquezas nesse tempo. A principal: prestei pouca atenção às regras morais, deixando-me seduzir pelas regras necessárias ao êxito. Depois, tive uma visão demasiado estreita das coisas. Por exemplo, estabeleci para mim muitas regras que podiam ser reduzidas a uma - não ter vaidade. Esqueci que a condição necessária para o êxito é a confiança em si próprio, o desprezo pelas ninharias o qual não pode provir senão da elevação moral.

[21 de março] 20. Pela manhã, escrevi, li. Escrevi pouco, não estava de bom-humor e temia corrigir. Regra. É melhor experimentar e estragar (uma coisa que pode ser refeita), do que não fazer nada.

[22 de março] 21 Trabalhei bastante bem, exceto pela falta de firmeza, e com desejo de exibir-me. Almocei em casa. Em relação ao dinheiro, não fiz nada nem tive nenhuma ideia

\footnotetext{
${ }^{54}$ Primeira redação de "Infância”. A este trabalho se referem as anotações posteriores.
} 
(planejei). Enganei-me. Tomei notas ${ }^{55}$, escrevi observações e o diário, com demasiada pressa. Um bom livro é possível escrever: A vida de Tatiana Aleksándrovna.

24 [março]. Levantei-me um pouco tarde e li, mas não pude escrever. Chegou Puare, pôs-se a esgrimir, não o mandei embora (preguiça e covardia). Chegou Ivanov, conversei tempo demais com ele (covardia). Koloshin (Serguei) veio beber vodka; não o despachei (covardia). Em casa de Ózerov discuti acerca de uma bobagem (hábito de discutir) e não falei do que era necessário; covardia. Não estive em casa de Beklemíshev ${ }^{56}$ (fraqueza de energia). $\mathrm{Na}$ ginástica, não passei a barra-trave (covardia) e não fiz uma coisa porque sentia dor (delicadeza). Em casa de Gortchakov, menti; mentira. Na taberna de Novotroitsk (pouco fierté*). Em casa, não estudei inglês (falta de firmeza). Em casa dos Volkónski fui afetado e, distraído e quando fui ver era já uma hora. (Distração, desejo de exibir-me, e fraqueza de caráter).

[Atividades para] 25. Das 10 às 11, diário do de ontem e ler. Das 11 às 12, ginástica. Das 12 à 1, inglês. Beklemíshev e Beer da 1 às 2. Das 2 às 4, cavalgar. Das 4 às 6 , almoçar. Das 6 às 8 , ler. Das 8 às 10, escrever. Traduzir alguma coisa de uma língua estrangeira para o russo para desenvolvimento da memória e do estilo. Escrever o dia de hoje com todas as impressões e pensamentos que ele suscitar ${ }^{57}$.

31 [de março] li, sem haver continuado o diário, e tarde. Fiz as contas até as 12. Das 12 às 2 falei com Begítchev, com demasiada franqueza, de forma vaidosa e enganando a mim próprio. Das 2 às 4, ginástica. Pouca firmeza e pouca paciência. Das 4 às 6 almocei e comprei coisas desnecessárias. Em casa, não escrevi; preguiça. Por muito tempo, não me decidi a ir a casa dos Volkónski. Ali, falei debilmente. Covardia. Comportei-me mal. Covardia, vaidade, irreflexão, fraqueza, preguiça.

[5 de abril. Pirogovo ${ }^{58}$ ]. Pela manhã, trabalhei bem, fui caçar e, a Pirogovo sem motivo. Em casa de Serioja, menti, fui vaidoso e covarde.

\footnotetext{
${ }^{55}$ Nessa época, Tolstói estava a ler as obras de Alphonse de Lamartine Histoire des Gerondines, o romance Geneviève, histoire d'une servante e o poema Jocelyn. Ele fazia resumos do lido, que acompanhava de suas observações.

${ }^{56}$ A identidade do Beklemíshev mencionado em mais de uma ocasião nos diários, não tem sido estabelecida. Na opinião de A. S. Petrovski, trata-se do proprietário G. A. Beklemíshev, com quem Tolstói tinha assuntos de dinheiro (negócios)(P.S.S. Vol. 46, pag. 343). B. M. Eikhenbaum disse que é A.P. Beklemíshev, membro do círculo de Petrachévski ("Russkaia Literatura", 1959, No 4, pg. 219).

* Em francês no original. Fierté: orgulho.

${ }^{57}$ Aqui e mais adiante, fala-se sobre uma das primeiras experiências literárias de Tolstói, que ele chama "História do dia de ontem".

${ }^{58}$ Pirogovo é uma Propriedade de S. N. Tolstói em Krapívieiski, distrito da Província de Tula.
} 
[Atividades para dia] 6. Das 5 às 10, escrever. Das 10 às 11 , missa. Das 12 às 4 , almoço. Das 4 às 6, ler. 6 às 10, escrever.

6 [de abril] Não consegui cumprir nada. Menti e muita vaidade, fiz jejum levianamente e de maneira distraída. Perturbou-me muito a história com Helke; Hoje, depois do almoço, descrevê-la-ei ${ }^{59}$. Quero escrever sermões.

17 [de Abril] Não escrevi nada. A preguiça venceu-me!! Hoje quero começar a história de um dia de caça ${ }^{60}$. Conversei durante muito tempo com titia. Ela é muito boa e de alma muito elevada, mas muito limitada. Ela tem uma linha na qual ela sente e pensa; fora dela, nada.

Não há melhor forma de saber se progredimos, no que quer que seja, do que experimentarmo-nos no modo antigo de fazer as coisas. Para saber se crescemos ou não, precisamos medir-nos com a medida antiga (pela craveira antiga). Depois de quatro meses de ausência, vejo-me de novo na mesma moldura. Em relação à preguiça, sou quase o mesmo. Em relação à volúpia, a mesma coisa. Quanto a saber tratar os servos (súditos, subordinado, subalterno), um pouco melhor. Mas aquilo em que eu avancei é a disposição de espírito.

19 [de Abril]. Chegaram Nikólenka ${ }^{61}$, Valerian e Macha ${ }^{62}$. Amanhã irei a Tula, tomarei uma decisão acerca do serviço e cederei Vorotynka por dezesseis mil em notas ${ }^{63}$. Tornei-me ainda mais religioso na aldeia.

[20 de Maio. No caminho de Sarátov a Ástrakhan ${ }^{64}$ ] No dia 20 de abril eu já não escrevia o diário e isso prolongou-se até o dia 20 de maio. Porém, eu me lembrarei dia após dia, desse mês. Ele é muito interessante.

O último tempo passado por mim em Moscou é interessante pelo meu desprezo à sociedade e pela incessante luta interior. Chegada à aldeia. Tula. Sherbátov pareceu bondoso,

\footnotetext{
${ }^{59}$ Helke é um dos conhecidos de Tolstói de Tula. É um oficial. Não está estabelecido em que acaba essa história. Tolstói não realizou seu objetivo de descrevê-la.

${ }^{60}$ Esta ideia achou sua realização (cristalização) na novela Infância, nos capítulos "A preparação para a caça" e "A caçada".

${ }^{61}$ N. N. Tolstói chegou a Iásnaia Poliana de Pokrovskoe antes do regresso ao Cáucaso.

${ }^{62}$ V. P. Tolstói e sua esposa Maria Nikoláievana, irmã de Tolstói.

${ }^{63}$ Quer dizer, demitir-se do serviço no Conselho Administrativo da Província de Tula onde Tolstói contava como funcionário do escritório da Assembléia de Deputados da Nobreza de Tula.

${ }^{64}$ A aldeia Vorotynka, localizada no distrito de Bogoroditski, na província de Tula. 22 servos foram herdados a Tolstói após a divisão da herança com os irmãos. Com ajuda de V. P. Tolstói, a aldeia foi vendida em 7 de junho de 1851 a D. S. Siéleznev, proprietário rural da região de Tula.
} 
um encanto de pessoa. Arsiénev está doente. Em Iásnaia, por volta do horário da missa ${ }^{65}$. Em Pirogovo, está Masha ${ }^{66}$. Serioja cai moralmente. Jejum, sermões. Na Páscoa, ir a Iásnaia, a Tula: Isliénev, Tchulkov, Perfílev, Chulera, Arsiénev. Hartung. À noite ir para Pokrovskoe, por alguns dias, Valerian, Macha. Voltar para Tula. Em Iásnaia. Ir a Tula. Isliénev, Selezniov. Moscou, Kóstenka. Zubkov. Nikólenka. Viagem. Em Kazan. Os Shuválov. Zybin, Zagóskina, Ogólen, os Iushkov. Sarátov. O maior. Alemães. Panorama. Tempestade. Pecadores. Alemães ${ }^{67}$.

[30 de maio. Staragladkovskaia]. Escrevo no dia 30 de Junho, às 10 horas da noite, na stanitsa $^{68}$ Staragladkovskaia. Como vim parar aqui? Não sei. Para que? Também não. Gostaria de escrever muito: acerca da viagem de Ástrakhan à stanitsa, acerca dos cossacos, da covardia dos tártaros e acerca da estepe, mas os oficiais e Nikólenka vão jantar à casa de Aleksiéev, irei também eu. Estou predisposto a gostar do capitão, mas a afastar-me dos outros. Sórdidos, (parece-me) talvez.

\footnotetext{
${ }^{65}$ Em russo, obednia: missa realizada entre às 10 horas e as dezesseis, coincidindo, mais ou menos, como o horário do almoço (em russo, obed).

${ }_{66}^{66}$ Macha, cigana de Tula, M. M. Chíchkina. Foi a esposa de S. N. Tolstói desde 1867.

${ }^{67}$ À época existia uma república autônoma alemã na região, de colonos alemães, parte do contingente de pessoas trazidas pela Imperatriz Catarina a Grande que governou a Rússia de 1762 - 1796. Tal república existiu até pouco antes da Segunda Guerra Mundial (N. de T).

${ }^{68}$ Povoado de cossacos (N. de T.).
} 


\section{CADERNO D}

$[\text { Março - maio de } 1851]^{69}$

L'imagination est le miroir de la nature, miroir que nous portons en nous et dans lequel elle se peint. La plus belle imagination est le miroir le plus clair et le plus vrai, celui que nous [...] appelons le genie. Le genie ne creé pas, il retrace.

Il y a des hommes qui ont le sentiment du bon, du Beau et du noble mais qui ne le sont $\operatorname{pas}^{70}$.

Existem pessoas que compreendem rapidamente tudo o razoável, simpatizam vivamente com tudo o elegante e sentem tudo o que bom, mas na vida, na prática, elas não são nem inteligentes, nem elegantes nem boas. Por que é isso? Ou bem possuem duas capacidades: receptividade e reprodução ou bem não basta aquela capacidade que chamam gênio ou talento, ou, afinal, as naturezas demasiado puras são sempre fracas e apáticas e por isso as capacidades não são desenvolvidas.

Je n'étais pas assez gai pour avoir un ami, j'étais trop isole pour avoir une amie.

Chez certains hommes l'aveu public de la faut qu'on [a] commis avec eux, augmente l'amour jusqu'à ce qu'ils se fassent une arme de cet aveu contre la femme oui l'a fait. Ce sont les natures basses.

Dernièrement en parlant avec un de mes amis qui se plaignait de sa position et qui lui attribuait toutes les bévues qu'il avait faites, je disais, que ni la richesse, ni le nom, ni l'élégance ne pouvaient donner à un homme l'aplomb, qui était la cause de ses bévues, s'il lui manquait. - C'est une chose que je ne puis vous prouver, me dit-il mais que je connais par un triste expérience : le jours, que j'ai une chemise, je suis tout autre, que quand j'ai un faux-col, et comme le héros d'un roman d'Eugène Sue, qui partage ses jours de pluie et de beau temps, je partage mes jours en jours de chemise et de faus-col.

Que as personalidades ricas são preguiçosas e se desenvolvem pouco é coisa que, primeiro, vemos na realidade, segundo, é claro que as personalidades imperfeitas tendem a desvendar as trevas que lhes encobrem muitas questões e atingem o aperfeiçoamento e adquirem o costume de trabalhar. Depois: o trabalho que devem fazer as personalidades ricas

\footnotetext{
${ }^{69}$ Com as seguintes anotações (sem data) inicia-se o caderno que Tolstói designa como caderno "D”. Pelos resumos dos livros e as reflexões sobre o lido, vinculam-se, provavelmente, ao período de estada de Tolstói em Moscou, em março de 1851, ou à viagem ao Cáucaso, realizada entre 20 de abril e 30 de maio de 1851, seguidas pelas habituais anotações de diário, que começam em 2 de junho.

${ }^{70}$ Citação, em francês no original, do romance Geneviève de Alphonse de Lamartine (N. de T.).
} 
para ir adiante no desenvolvimento posterior, é muito maior e não é proporcional ao trabalho das personalidades imperfeitas.

Lamartine diz que os escritores perdem de vista a literatura do povo, que o maior número de leitores está entre o povo, que todos os que escrevem, escrevem para o círculo em que vivem, e que o povo, em meio ao qual há pessoas sedentas de ilustração, não possui literatura e não a possuirá enquanto não começarem a escrever para o povo.

Não vou falar sobre aqueles livros que são escritos com o objetivo de encontrar muitos leitores -isso não são obras literárias, mas produtos do ofício de autor-, nem acerca daqueles livros científicos e manuais que não penetram no campo da poesia.

(Onde estão as fronteiras entre prosa e poesia, eu nunca o entenderei. Embora exista uma questão acerca dessa matéria na filologia. Mas é impossível entender a resposta. A poesia são versos. A prosa, não são versos. Ou, a poesia é tudo exceto os papéis de negócios e os livros didáticos). Todas as obras, para serem boas, como disse Gógol em sua novela de despedida $^{71}$ (ela saiu da minha alma), devem sair da alma do autor.

Se aquilo que é acessível para o povo, pode sair da alma dos autores -que, na sua maioria se encontram no grau mais elevado de desenvolvimento-, o povo não o entenderá. Até se o autor se esforçar em descer até o degrau do povo, este não entenderá assim. Do mesmo modo como um rapaz de dezesseis anos lê a cena do estupro da heroína de romance e isto não suscita nele o sentimento de indignação, ele não se coloca no lugar da infeliz, mas, involuntariamente, transfere-se para o papel do sedutor e deleita-se com o sentimento de volúpia, - da mesma forma o povo, de tudo aquilo que quiseres (que vós quiserdes) dizer-lhe, entenderá algo completamente diferente. Será que o povo entenderá Anton Goremyka ${ }^{72}$, Geneviève? As palavras são acessíveis, como expressões do pensamento, mas os pensamentos não são acessíveis. O povo tem a sua literatura - bela, inimitável; mas ela não é uma falsificação. Ela sai do seio do próprio povo. Não há necessidade de literatura elevada (superior) e ela não existe. Experimentai colocar-vos exatamente no nível do povo: este começará a desprezar-vos.

\footnotetext{
${ }^{71}$ Tolstói tinha em vista as palavras de Gógol (provenientes) do seu "Testamento" ("Fragmentos escolhidos da sua correspondência com os amigos"). Evidentemente, ele chama "novela de despedida" a segunda parte de Almas Mortas.

${ }^{72}$ Anton Goremyka é uma novela de D. V. Grigoróvitch (1847).
} 
Que sigam os altos círculos enfrente, o povo não ficará para atrás: ele não se fundirá com o alto círculo, mas ele também avançará. Pourquoi dire dês subtilités, quand il y a encore tant de grosses vérités à dire*. Procuravam pela pedra filosofal, e encontraram muitas combinações químicas. Estão a buscar virtudes da perspectiva do socialismo isto é, a ausência de vícios, e encontrarão muitas verdades morais úteis.

Como muda nosso modo de encarar a vida quando vivemos, não para nós, mas para os outros! A vida deixa de ser o objetivo e torna-se o meio. A infelicidade produz o virtuoso; a virtude produz o feliz; a felicidade produz o vicioso.

Há dois tipos de felicidade: a felicidade das pessoas virtuosas e a felicidade das pessoas vaidosas. A primeira provém da virtude, a segunda, do destino. É necessário que a virtude deite raízes profundas, para que a última não exerça uma influência prejudicial na primeira. A felicidade, baseada na vaidade, é destruída por si própria: a glória pela maledicência, a riqueza pelo engano. A felicidade baseada na virtude, não é destruída por nada.

Dizer que a vida são só provações e que a morte é um bem, apartando-nos com isso de todas as amarguras - nós não devemos. Isso não é nem consolo na perda de entes queridos, nem ensinamento moral. Concordar com isso é impossível senão no desespero, e o desespero é uma fraqueza da fé e da esperança em Deus. Como ensinamento moral tal pensamento, para uma alma jovem, é grave demais para não abalar-lhe a fé na virtude (Como ensinamento moral tal pensamento é grave demais para uma alma jovem, e não há como ele não abalar-lhe a fé na virtude // e só pode por isso abalar-lhe a fé na virtude). Se uma pessoa for privada de um ser a quem amava, ela pode amar outro; Se não o faz, é porque ela é demasiado orgulhosa. O princípio do mal está na alma de cada um.

Todos descrevem as fraquezas humanas e o lado ridículo das pessoas transferindo-os a personalidades inventadas, às vezes com êxito, na medida do talento do escritor, mas na maioria das vezes, de modo artificial. Por quê? Porque nós conhecemos as fraquezas humanas por nós mesmos e para mostrá-las corretamente, é preciso que as mostremos em nós, pois uma dada fraqueza fica bem apenas a uma dada personalidade.

\footnotetext{
* Para que falar em bagatelas, quando ainda resta falar sobre muitas verdades importantes (em francês no original).
} 
A poucos alcançam as forças para fazer isso. As pessoas esforçam-se por deformar o mais possível a personalidade à qual transferem as suas próprias fraquezas, para elas mesmas não se reconhecerem. Não é melhor dizer diretamente: "Eis como eu sou. Não lhes agrada, sinto muito: mas foi assim que Deus me fez". Ninguém quer dar o primeiro passo, para que não se diga, por exemplo: "acha que se você é ruim e ridículo, então todos nós também o somos". Por isso, todos se calam.

Isso parece como na província as pessoas vão ao baile: todos temem ser os primeiros em chegar e, assim, todos chegam tarde. Mostre-se cada um tal como é e, então, o que antes era ridículo e uma fraqueza deixará de sê-lo. Não será um enorme bem livrarmo-nos, ainda que só um pouco, deste horrível jugo - o medo ao ridículo? Quantos, quantos verdadeiros deleites perdemos por causa desse medo estúpido! - Ne pouvant ni rester sous un passé qui croule, ni jeter d'un seul jet l'avenir dans son moule (Lamartine, Joceline) ${ }^{73}$. La supériorité est une infirmité sociale (Emile Souvestre $)^{74}$.

2 de Junho de 1851. Ah!, Meu Deus, meu Deus, como há dias penosos! E de onde tanta tristeza? Não, não é tão triste, quão dolorosa a consciência de que estás triste e não sabes o motivo da tristeza. Eu pensava antes: isso é da inatividade, da ociosidade. Não, não é por causa da ociosidade mas sim desta situação, que eu não posso fazer nada. O principal é que eu não encontro em lugar nenhum nada parecido à tristeza que experimento: nem em descrições, nem sequer na minha imaginação.

$\mathrm{Eu}$ imagino que se possa ficar triste por alguma perda, por uma separação, por uma esperança desmentida. Eu entendo que se possa decepcionar-se: tudo enfastia (acaba por enfastiar-nos); somos tantas vezes enganados em nossas esperanças (expectativas), que passamos a não esperar mais nada. Eu entendo quando se ocultam na alma o amor por tudo o belo, ao ser humano, à natureza; Quando estás disposto a manifestar tudo isso e pedir um eco de simpatia e, por toda parte, encontras frieza e escárnio, maldade dissimulada contra as pessoas e, daí a tristeza.

\footnotetext{
${ }^{73}$ Não se pode ficar sob os destroços de um passado que rui, nem dar de uma vez sua forma nova ao futuro (Lamartin, Joceline).

${ }^{74}$ A superioridade é uma doença social (Emile Souvestre)
} 
Eu entendo a tristeza de uma pessoa quando a sua situação é amarga e o penoso e venenoso sentimento de inveja oprime-o. Tudo isso eu compreendo e, em cada tristeza desse tipo há algo bom, por um lado.

Já a minha própria tristeza, eu a sinto mas não posso entendê-la nem imaginá-la. Não há nada por lamentar e também quase nada por desejar, nem por que revoltar-me contra destino. Eu entendo quão agradável seria viver da imaginação. Mas não. A imaginação não me desenha nada- não há sonho. Desprezar as pessoas é também para nós não sei que sombrio deleite, mas também disso não sou capaz, eu nem penso nelas; Ora parece-me: esta pessoa tem uma alma boa, simples; ora parece-me não: é melhor não procurar; Para que errar!

Desilusão também não há; tudo me atrai. Mas a desgraça é que eu, demasiado cedo comecei a ocupar-me de coisas sérias da vida, comecei a ocupar-me delas quando ainda não estava maduro para elas, e apenas as sentia e compreendia; assim, eu não tenho fé forte na amizade, no amor, na beleza, e decepcionei-me com coisas importantes na vida. Já nas ninharias, sou uma criança.

Agora eu penso, ao lembrar-me de todos os minutos desagradáveis da minha vida, os únicos que na melancolia vêm à cabeça: não, há demasiado poucos deleites e desejos demais, é o homem demasiado capaz de imaginar a felicidade, e demasiada freqüência, assim por nada, o destino golpeia-nos dolorosamente, toca-nos dolorosamente nas cordas sensíveis para que amemos a vida. E depois, há algo especialmente doce e grandioso na indiferença à vida e eu me deleito com esse sentimento.

Quão forte eu me pareço contra tudo, com a firme convicção de que aqui não há nada por que esperar, além da morte; e agora ainda penso, com deleite em que tenho encomendada uma sela na qual vou cavalgar de tcherkeska ${ }^{75}$, e como vou arrastar a asa às cossacas e entrar em desespero pelo fato de o meu o bigode esquerdo ser pior do que o direito, e eu terei de ficar duas horas diante do espelho a endireitá-lo. Também não consigo escrever e a julgar por isso, é uma bobagem.

\footnotetext{
${ }^{75}$ Espécie de cafetã comprido e estreito dos caucasianos y cossacos (N. do T.).
} 
Et puis cette horrible nécessité de traduire par des mots et aligner en pattes de mouches des pensées ardentes, vives, mobiles, comme des rayons de soleil teignant les nuages de l'air. Oủ fuir le métier, Grand Dieu! ${ }^{76}$

8 de junho [Staryi Yurt ${ }^{77}$ ] Amor e religião - eis dois sentimentos puros, elevados. Não sei a que chamam amor. Se o amor for aquilo que dele li e ouvi, então, nunca o experimentei. Eu via antes a Zinaída como normalista e ela agradava-me; mas eu a conhecia pouco (que coisa tosca é a palavra! Quão obscena e estupidamente saem os sentimentos comunicados). Vivi em Kazan ${ }^{78}$ uma semana. Se me perguntassem para que vivi eu em Kazan, o que me era agradável ali, porque era eu tão feliz, eu não diria que isso seja por eu estar apaixonado.

$\mathrm{Eu}$ não o sabia. Parece-me que precisamente esse desconhecimento é que é o traço principal do amor e constitui todo o seu encanto. Quão bem me sentia eu no aspecto moral, nesse tempo.

Eu não sentia o peso de todas as paixões mesquinhas, que estragam todas as delícias da vida. Eu não lhe disse nenhuma palavra de amor, mas eu estou tão convencido de que ela sabe dos meus sentimentos que, se ela me amar, então, eu atribuirei isso apenas ao fato de ela haver-me compreendido. Todos os ímpetos da alma são puros, elevados no seu princípio. A realidade aniquila a inocência e encanto de todos os impulsos. As minhas relações com Zinaída permaneceram no degrau da pura atração de uma alma pela outra. Mas talvez tu duvides que eu te ame, Zinaída; Perdoa-me; se isso é assim, eu sou o culpado; E com uma palavra só eu poderia fazer-te acreditar nisso.

Será que não a verei jamais? Não é possível que um dia eu ficarei sabendo que ela se casou com um Bekétov qualquer ou, o que seria ainda mais lamentável, eu a verei alegrinha, de chapeuzinho, com aquele mesmo olhar inteligente, aberto, alegre e apaixonado. Eu não abandonarei os meus planos para ir casar-me com ela; eu não estou suficientemente convencido de que ela possa constituir a minha felicidade; mas, apesar de tudo, eu estou apaixonado.

\footnotetext{
${ }^{76} \mathrm{E}$ depois, essa horrível necessidade de traduzir em palavras e ordenar em garranchos pensamentos ardentes, vivos, móveis como os raios do sol que tingem as nuvens do ar [...] Para onde fugir do ofício, Grão Deus! (em francês no original). Citação do romance Horace de George Sand.

${ }^{77}$ Campo fortificado e povoado tchetcheno perto de Goriatchevodsk.

${ }^{78}$ Kazan, capital da República Tártara.
} 
Senão, que são essas doces lembranças que me reanimam; que é esse olhar dentro do qual olho, tão logo vejo, sinto algo belo? Será que não devo escrever-lhe uma carta? Não sei o seu patronímico ${ }^{79}$ e por isso talvez fique privado da felicidade. É ridículo. Esqueceram-se de pegar a camisa com pregas e por isso não estou no serviço militar. Se tivessem esquecido o quepe, eu nem pensaria em aparecer diante de Vorontsov e servir em Tíflis. De papakha ${ }^{80}$ é que eu não poderia! Agora, sabe lá Deus o que me espera. Deixo tudo nas suas mãos. Eu próprio não sei o que é necessário para a minha felicidade nem o que seja a felicidade.

Lembras o jardim do bispo, Zinaída, o caminho lateral. Tenho na ponta da língua a minha confissão e tu também. A mim tocava o começar; mas, sabes por que me parece que eu não disse nada? Eu estava tão feliz, que não havia nada que pudesse desejar e temia estragar a minha... não a minha, mas a nossa felicidade. Esse tempo lindo permanecerá para sempre como as melhores lembranças da vida.

E que criatura vazia e vaidosa é o homem. Quando me perguntam do tempo passado por mim em Kazan, eu respondo em tom displicente: "sim, para uma cidade de província, uma sociedade até respeitável (boa, digna) e eu passei lá alguns dias muito felizes”. Infame! As pessoas reduziram tudo ao ridículo. Riem-se da afirmação de que a companhia da pessoa amada faz duma cabana um palácio, e dizem que ela é uma inverdade.

Subentende-se, ela é verdade; não apenas em uma cabana, mas também em Krapivna e Staryi Yurt e em todos lugares. "Na companhia da pessoa amada, uma cabana torna-se o paraíso" O amor e uma cabana e isto é verdade, verdade, cem vezes verdade.

(11 de junho de 1851. Cáucaso. Staryi Yurt, acampamento. Tarde da noite) Vivo já aqui há uns cinco dias e tolhido por uma preguiça que eu esquecera havia muito. Larguei por completo o diário. A natureza, em que eu pusera mais esperanças do que em qualquer outra coisa, quando pensava vir ao Cáucaso, até agora não representou nada de sedutor. A galhardia, que eu pensava que se manifestaria em mim aqui, também apareceu ainda.

\footnotetext{
${ }^{79}$ Patronímico

${ }^{80}$ Papakha: gorro alto de pele, usado pelos caucasianos e pelos cossacos (N. do T.).
} 
Noite clara, um ventinho fresco percorre a tenda e faz vacilar a luz da vela já consumida vela. Ouve-se um longínquo latir de cachorros no aul ${ }^{81}$ e os gritos do rondante para as sentinelas. Cheira aos galhos de carvalho e plátano que compõem a armação da barraca. Eu estou sentado sobre um tambor na barraca, cada lado da qual encosta numa tenda, uma, fechada, na qual dorme Knoring (um oficial desagradável) e a outra aberta e completamente escura, exceto por uma faixa de luz que cai nos pés do leito do meu irmão.

Diante de mim o lado bem iluminado da barraca, no qual está pendurada a pistola, o sabre, o punhal e as ceroulas. Tudo esta em silêncio. Ouve-se soprar o vento, perpassa um besouro, e rodeia o fogo; perto um soldado soluça e deixa escapar um queixume. Não tenho vontade de dormir; e para escrever, não há tinta. Até amanhã. À medida das impressões do dia, escreverei também cartas.

[Atividades para o dia 12] Das 5 às 8 , escrever. Das 8 às 10, nadar e desenhar. Das 10 às 12 , ler. Das 12 às 4 , descanso. Das 4 às 8 , tradução do inglês ${ }^{82}$. A partir das 8 escrever. Continuar a fazer ginástica e o livro contábil e o de Franklin.

[12 de junho] 11 de junho. Levantei-me tarde; Acordara-me Nikólenka, ao chegar da caça. Eu, procuro o tempo todo por uma certa disposição de espírito, por uma maneira de ver as coisas, por um certo modo de vida que não consigo nem encontrar nem saberia definir. Eu gostaria de mais ordem na atividade intelectual, de mais atividade em si e, ao mesmo tempo, de mais liberdade e espontaneidade. Ontem não dormi quase a noite inteira; depois de escrever um pouco o diário, pus-me a orar a Deus. A doçura do sentimento experimentado na prece é impossível expressar. Li as preces que costumo criar: Pai, à Nossa Senhora, à trindade, à porta da misericórdia, a invocação ao Anjo da guarda e, depois, detive-me em uma delas. Se a oração é definida como um pedido ou agradecimento, então, eu não orei. Eu desejava algo

\footnotetext{
${ }^{81}$ Localidade rural dos povos turcos. Nas montanhas do Cáucaso, principalmente no Daguestão, os aul são povoados fortificados. As casas nos aul são frequentemente construídas de pedra e na encosta da montanha, para defender a população de ataques inesperados. No século XIX, durante a guerra russa no Cáucaso, os Aul foram pontos defensivos resistentes que, na maioria dos casos, só conseguiam ser tomados por assalto. No norte do Cáucaso, a população eslava tradicionalmente chama aul todas as localidades não cristãs. Para os povos do Kazaquistão, Ásia Central e Basquíria, esse termo designava, inicialmente, os povos nômades. O estabelecimento dos aul como localidades permanentes, está ligado ao passo da vida nômade à vida sedentária durante 0 século XIX e começo do século XX $\quad$ (disponível em http://ru.wikipedia.org/wiki/\%D0\%90\%D1\%83\%D0\%BB último acesso, 28/03/2010).

${ }^{82}$ Tolstói estava a traduzir Uma viagem sentimental através da França e da Itália de Laurence Sterne. Alguns fragmentos dessa tradução (aprecem, fazem parte) das Obras completas, Vol. I.
} 
elevado e bom, mas o que, eu não consigo expressar, embora tivesse clara consciência do que desejava. Eu gostaria de fundir-me com o ser que tudo abarca.

Eu lhe pedi que perdoasse os meus crimes. Mas não, eu não lhe pedi isso porquanto eu sentia que se ele dera aquele minuto beatífico, era porque me perdoara. Eu pedia e ao mesmo tempo sentia que não tinha nada que pedir e que eu não podia e não sabia pedir. Eu agradecia, sim, mas não com palavras, não com pensamentos. Eu, em um único sentimento, juntava tudo: a súplica e a gratidão. O sentimento de medo desaparecera completamente.

Eu não conseguia separar do sentimento geral nem um único dos sentimentos de fé, esperança e amor. Não; eis um sentimento que experimentei ontem: o amor a Deus. Um amor elevado que reúne em si todo o bom e que recusa todo o mal.

Quão terrível me era olhar para todo o lado mesquinho, depravado, da vida. Eu não conseguia conceber como ele pudera atrair-me. Eu pedia de coração puro a Deus que me recebesse no seu seio. Eu não sentia a carne; eu era só espírito. Mas não! O lado carnal, mesquinho, venceu de novo, se impôs e não passou nem sequer uma hora, e eu já ouvia, quase conscientemente, a voz do vício, da vaidade, do lado vazio da vida. Eu sabia de onde vinha essa voz, sabia que ela arruinaria a minha bem-aventurança, lutei, lutei, lueti e rendi-me a ela. Eu adormeci sonhando com a glória, com as mulheres; Mas não sou culpado; não pude fazer nada.

A bem-aventurança eterna aqui é impossível. Os sofrimentos são necessários. Para quê? Não sei. E como ouso dizer "não sei"? Como ousei pensar que se pudessem conhecer os caminhos da Providência. Ela é a fonte da razão e a razão quer compreender... A inteligência perde-se nesses abismos de sabedoria e o sentimento teme ofendê-la. Agradeço a ela o minuto de beatitude que me mostrou a minha insignificância e a minha grandeza. Quero rezar, mas não sei; quero compreender, mas não ouso; entrego-me à Tua vontade. Para que escrevi eu tudo isso? De que modo tão vulgar, frouxo e até absurdo se expressaram os meus sentimentos, e eram tão elevados!!

Passei a manhã bastante bem, tive um pouco de preguiça, menti, mas sem pecado. Amanhã escreverei uma carta a Zagoskiná, ainda que não a passe a limpo. Estive desenhando sem esmero. No fim da tarde, fiquei a admirar as nuvens. Estavam bonitas durante o declinar 
do sol. O Oeste estava vermelho, mas o sol estava ainda à distância de uma braça do horizonte. Acima dele, redemoinhavam nuvens maciças, cinzento-escarlates. Elas se uniam um tanto desajeitadamente. Eu comecei a falar com alguém e voltei-me. Pelo horizonte, estendia-se uma escura faixa cinzento avermelhada, que terminava em figuras sempre variadas, ora, inclinando-se uma para as outras, ora, dispersando-se, com bordas de um vermelho brilhante.

O homem foi criado para uma vida de retiro - de retiro não no sentido literal, mas no sentido moral. Existem alguns sentimentos que não devem ser confiados a ninguém. Se forem sentimentos belos, elevados, tu decairás no conceito da pessoa a quem os houveres confiado ou até simplesmente dado a possibilidade de adivinhá-los. Quando os confia, a pessoa não tem deles plena consciência e apenas expressa as suas aspirações. O desconhecido é o que tem o maior poder de atração. Eu e o meu irmão vivemos agora entre um certo tipo de gente, entre o qual nos é impossível não ter consciência da nossa superioridade sobre os outros. Mas falamos pouco entre nós, como se temêssemos que, ao dizermos alguma coisa, permitimos que se adivinhe o que queremos ocultar de todos. Conhecemos um ao outro demasiadamente bem.

Impressionaram-me três coisas: 1) as conversas dos oficiais sobre a coragem. Começava-se a falar de alguém. É ele corajoso?

Sim, mais ou menos. Todos são corajosos. Semelhante tipo de conceito de coragem pode explicar-se assim: a coragem é o estado do espírito em que as suas forças agem sem alterar-se, quaisquer que sejam as circunstâncias. Ou a intensidade de atuação que nos priva da consciência dos perigos. Ou existem dos gêneros de valentia: moral e física.

A valentia moral, que provém da consciência do dever e, em geral, das inclinações morais e não da consciência do perigo. A física é aquela que provém da necessidade física, sem se perder a consciência do perigo e aquela em que esta consciência se perde. Exemplos da primeira: o homem que, de boa vontade, sacrifica a si próprio pela salvação da pátria ou do indivíduo (de alguém). 2) $\mathrm{O}$ oficial que serve às vantagens. 3) Soldados russos lançaram-se às mãos do inimigo na campanha turca só para embriagar-se. Aqui há apenas um exemplo de valentia física.

13 de junho. Eu continuo com preguiça, embora esteja satisfeito de mim, exceto pela volúpia. Algumas vezes, quando os oficiais falaram sobre as cartas diante de mim, eu gostaria 
de mostra-lhes que eu amo jogar. Mas, eu me contenho. Espero que, mesmo que eles me convidem, eu me recuse.

3 de julho. Eis o que eu escrevi 13 de junho e perdi todo este tempo porque nesse mesmo dia fui atraído e perdi 200 meus, 150 de Nikolái e 500 emprestados. Em total, 850. Agora, contenho-me e vivo de forma consciente. Estive na incursão ${ }^{83}$. Também agi mal: de forma inconsciente e tive medo de Bariatínski. Além disso, sou tão débil, tão depravado, fui tão pouco sensato que devo deixar-me influenciar por qualquer Bariatínski... Amanhã escreverei o romance ${ }^{84}$, traduzir e direi a Knoring que espere e esforçar-me-ei em conseguir dinheiro. Na quarta-feira irei para Grózni.

Agora estou deitado fora do campo.Noite milagrosa! A lua acabou de sair de atrás de um montículo e iluminou duas pequenas e finas nuvenzinhas baixas. Atrás de mim, o grilo assobia seu melancólico e incessante canto. Ao longe, ouve-se a rã e perto do aul ${ }^{85}$ ora se escuta o grito do tártaro ora o latido do cachorro. E, de novo, tudo fica calmo e, de novo, ouve-se só um assobio do grilo e arrasta-se uma nuvenzinha levezinha, transparente do lado das estrelas longínquas e próximas.

Comecei a pensar: irei e descreverei o que vejo. Mas como escrever isso. É necessário ir, sentar à mesa manchada de tinta, pegar o papel cinza e a tinta. Manchar-se os dedos e traçar letras pelo papel. As letras comporão palavras e as palavras, frases. Mas acaso é possível comunicar o sentimento. Poderia de alguma forma transmitir a outrem meu olhar diante do aspecto da natureza? A descrição é insuficiente. Por que está tão intimamente ligada a poesia à prosa, a felicidade à infelicidade? Como se deve viver? Deveria esforçar-me em unir de repente a poesia com a prosa ou desfrutar de uma e depois entregar-se a viver à vontade da outra?

No sonho existe um lado que é melhor do que a realidade. Na realidade existe um lado que melhor do que o sonho. A felicidade completa seria a união de um e outro.

\footnotetext{
${ }^{83}$ Em meados de Junho de 1851, Tolstói, como membro voluntário do destacamento comandado por A. I. Bariatínski, participou das ações militares contra os montanheses.

${ }^{84}$ O romance Quatro épocas do desenvolvimento. Assim deveria ter se chamado a tetralogia pensada por Tolstói: Infầncia, Adolescência, Juventude e Mocidade. A última parte não foi escrita.

${ }^{85}$ Aul: aldeia no Cáucaso e na Ásia Central (N. do T).
} 
4 de julho. Estou quase satisfeito de mim. Exceto porque durante esse tempo tenho estado meio vazio. Não tenho ideias. E se as tenho, então elas me parecem a tal ponto insignificantes, que não quero escrevê-las. Por que isso? Não sei. Haverei eu me deslocado para a posição crítica ou será que desci em no criativo? Amanhã irei ao aul e Grózni. Falarei com meu irmão sobre o dinheiro e decidirei sobre a viagem ao Daguestão. Decididamente, não posso escrever nada embora haja personalidades interessantes.

Quão sem sentido passam os dias! Eis o dia de hoje. Sem uma só lembrança, nem uma impressão forte. Levantei-me tarde com esse sentimento desagradável que age sempre em mim ao despertar. Fiz mal, fiquei dormido. Eu, quando acordo, sinto aquilo que sente o cachorro covarde diante do dono, quando é culpado. Depois pensai em quão frescas são as forças morais do homem ao despertar e em por que eu não consigo mantê-las sempre nesse estado.

Sempre vou dizer que a consciência é o maior mal moral que pode alcançar o homem. É doloroso, muito doloroso saber que eu, daqui a uma hora, ainda que seja o mesmo homem e que as mesmas imagens estejam na minha memória, mas minha visão (das coisas), sem depender de mim, muda e, ao mesmo tempo, é de maneira consciente. Estive lendo Horace. Meu irmão falou certo: essa personagem parece comigo. $\mathrm{O}$ traço mais importante: a nobreza do caráter, a elevação das ideias, o amor à glória e a incapacidade absoluta para qualquer trabalho. A incapacidade provém da falta de costume e a falta de costume da educação e da vaidade.

Almoçamos os três, como de costume: eu, meu irmão e Knoring. Tentarei traçar um retrato de Knoring. Parece-me que descrever um homem é, na verdade, impossível. Mas é possível descrever como ele age em mim. Dizer de um homem: é um homem original, bom, inteligente, bobo, consequente e assim por diante... palavras que não dão nenhuma ideia sobre o homem e têm a pretensão de caracterizar o homem e então, com quanta frequência só desorientam. Eu sabia que o meu irmão morou com ele em algum lugar e que chegou ao Cáucaso junto com ele e que foi bom com ele. Eu sabia que ele levava bem as despesas comuns, quer dizer, era um homem cuidadoso e que devia ser para meu irmão, isto é, era um homem superficial.

Como ele era amigo do meu irmão, eu concluí que não devia ser um homem mundano e como meu irmão contava pouco sobre ele, eu concluí que não devia caracterizar-se pela 
inteligência. Uma vez, pela manhã, meu irmão me disse: "Knoring estará aqui hoje. Como estou feliz de vê-lo". "Vejamos este janota". Pensei eu. De além da tenda, chegaram-me as expressões do encontro do meu irmão e uma voz que respondia a elas com tanta alegria: "Olá, focinhudo". Este é um homem indecoroso, pensei eu, e que não entende as coisas. Nenhum tipo de relação pode dar encanto a semelhante alcunha. Meu irmão, como é seu costume, recomendou-me a ele. Eu, já convencido do inútil, cumprimentei-o com frieza e continuei a ler deitado.

Knoring é um homem alto, de boa constituição, mas sem encanto. Eu reconheço que nessa compleição, há mais expressividade do que no rosto: há pessoas de compleição agradável e de compleição desagradável. O rosto é largo, de pômulos salientes que lhe dão uma certa suavidade; aquilo que nos cavalos é chamado "rosto carnoso". Os olhos são castanhos, grandes e possuem só duas expressões: o riso e a disposição normal. Durante o riso, eles permanecem fixos e têm uma expressão de estúpida insensatez. O resto no rosto é comum. Ele, conforme eu notei, se segurava diante de mim. Quando passaram os primeiros minutos do encontro, quando se repetiram algumas vezes as perguntas “o que é de você?” e a resposta "é, como você vê", ele se dirigiu a mim com a pergunta: "Veio por muito tempo, conde?". Eu, de novo, respondi com frieza. Eu tenho a capacidade de reconhecer, de imediato, as pessoas que amam exercer uma influência sobre os outros. Talvez porque eu próprio amo isto.

Ele é dessas pessoas. Sobre meu irmão, ele tem influência aparente. Por exemplo, chama-o para junto dele. Eu desejaria saber se é possível que um homem se esforce, de maneira consciente, por conseguir a influência sobre os outros. Isto me parece tão impossível, como é impossível fingir à livre ouvert *; Além do mais, eu tenho tentado isso. É por isso que praticamente não se chega a isso com as pessoas consequentes por esse meio. Tais pessoas têm esse tipo de segundas intenções em toda ação. Tantos pensamentos podem passar pela cabeça ao mesmo tempo, especialmente, por uma cabeça vazia.

10 de agosto de 1851. [Starogladkóvskaia] A noite do terceiro dia foi gloriosa. Eu fiquei em Starogladkóvskaia, junto à janelinha da minha khata ${ }^{86}$ e, com todos os sentidos, exceto o tato, desfrutei a natureza. O quarto minguante ainda não apareceu, mas no sudeste já começaram a arrebolar as nuvens noturnas, um ventinho suave trouxe um aroma fresco. As rãs e os grilos se fundiram em um uniforme e indeterminado som noturno. O horizonte estava

\footnotetext{
* Em francês no original. Improvisar um repente.

${ }^{86}$ Casa camponesa típica da Ucrânia (N. de T.).
} 
limpo e semeado de estrelas. Eu amo fitar a noite com o horizonte coberto de estrelas. É possível ver detrás das grandes estrelas brilhantes, as pequenas que se fundem em um lugar branco. Observas, as admiras e, de repente, tudo se oculta de novo. Parece que as estrelas tivessem se aproximado. Eu gosto desta ilusão de óptica.

Não sei como sonham os outros, mas, por quanto tenho lido e escutado, não é, e absoluto, como eu. Dizem que, ao ver a bela natureza, chegam pensamentos sobre a grandeza de Deus e a insignificância do homem. Os que estão apaixonados vêem na água a imagem da amada. Outros dizem que parece que as montanhas diziam isso, as folhas aquilo e que as árvores convidaram para tal lugar. Como pode vir tal pensamento? É necessário esforçar-se para que entre na cabeça semelhante estupidez. Quanto mais vivo, tanto mais concordo com diferentes artifícios (affectation ${ }^{87}$ ) na vida, na conversação e assim por diante.

Mas, apesar de todas as minhas forças, não posso me acostumar com esse artifício. Quando eu me ocupo disso que chamam sonhar, eu nunca consigo encontrar na minha cabeça nem um pensamento sensato. Ao contrário: todos os pensamentos que se passam pela minha imaginação são sempre os mais triviais; aqueles para os quais não se deve dar atenção. E quando eu me deparo com esse pensamento que carrega consigo uma sucessão de outros pensamentos, então, essa agradável disposição da preguiça moral que constitui meu devaneio, desaparece e eu começo a pensar.

Não sei como penetraram na minha imaginação as lembranças das noites ciganas. As canções, os olhos, o sorriso o peito e ternas palavras de Katina ainda estão frescas na minha memória. Para que escrevê-las, já que a história que quero contar não é sobre isso em absoluto. Noto que tenho o mau costume da digressão e que é exatamente este costume, e não a abundância de pensamentos, como pensava antes, o que com freqüência me impede escrever e me obriga a levantar-me da mesa de escritura e começar a pensar em outra coisa completamente diferente daquilo que estava escrevendo. Costume pernicioso. Apesar do enorme talento de narrar e conversar com inteligência do meu escritor preferido, Sterne, até ele faz pesadas digressões. Aquele que se relacionou com os ciganos não pode não ter o costume de cantarolar as canções ciganas. Queira bem, queira mal, mas isto sempre traz prazer porque faz lembrar de modo vivaz. Um traço característico que renova em nós muitas

${ }^{87}$ Em inglês no original. 
lembranças dos acontecimentos está ligado a esta característica. Na música cigana este traço é difícil de determinar. Ele consiste na entonação das palavras, em um gênero específico de enfeite e do acento.

Estava eu cantando junto à janela uma canção, se bem que não uma das minhas prediletas -«diz-me para que»-, mas uma canção que Kátia falou sentada nos meus joelhos na mesma noite em que me disse que me amava e que estava em boa disposição com os outros somente porque o coro assim o exigia, mas que a ninguém, exceto a mim, permitia as liberdades que devem estar cobertas pelo véu da discrição. Nessa noite eu, no fundo da alma, acreditei em toda sua astuta charlatanice cigana, estava em boa disposição e nenhum convidado me afligiu. Por isso amo a noite e essa canção. Eu cantava com grande animação. A timidez não segurou minha voz e não me fez confundir os tons; eu, com grande prazer, me escutava. A vaidade, como sempre, penetrou na minha alma e pensei: "é muito agradável para mim escutar-me, mas deve ser ainda mais agradável para os outros". Eu ainda invejei o prazer deles, do qual eu estava privado quando de repente, ao tomar ar e prestar atenção aos sons da noite para cantar com ainda mais sentimento a seguinte estrofe, escutei um sussurro sob a minha janelinha. "Quem está aí?" "Sou eu” me respondeu uma voz que não reconheci apesar da sua segurança de que essa resposta era absolutamente satisfatória. "Quem é «eu»" perguntei eu desgostado com aquilo que tinha perturbado meu sonho e meu canto, com esse profano. "Eu estava indo pra casa, parei e escutei”; “Ah, Marka?" "88"; “Sim, exato! É o senhor, parece-me, Vossa Excelência, gosta de cantar canções calmucas?”; "Que canções calmucas?”; "Sim, eu escutei - continuou ele sem notar minha aflição e ofensa- que a voz era parecida com os melodías deles"; "Sim, calmucos".

Tinha que ser o coxo do Marka com sua conversa estúpida que estragou meu prazer. Agora, claro, já não posso continuar nem a sonhar nem a cantar. Agora me veio a ideia de que canto muito mal, que o riso que ouvi no quintal vizinho foi provocado pela minha canção. Eu voltei em mim sob (o efeito) de uma impressão desagradável. Trabalhar também não pude, dormir não queria. Além disso, Marka, tal parecia, estava em boa disposição de espírito e foi um instrumento completamente inocente da decepção. Eu lhe manifestei meu assombro de que ele ainda não dormisse; ele me disse com muitas palavras extravagantes e incompreensíveis que tinha insônia. Entre nós se estabeleceu uma conversa. Ao saber que eu

\footnotetext{
${ }^{88}$ Marka / Luka Siejin era um jovem cossaco da stanitsa (aldeia de cossacos) Starogladkóvskaia. Alguns dos seus traços foram encarnados na personagem de Lukachka na novela Os cossacos.
} 
não queria dormir, ele pediu permissão para entrar, como o qual eu concordei, e Marka sentou-se encostando suas muletas na minha cama.

A personalidade de Marka que, no entanto se chama Luka é tão interessante e tão tipicamente cossaca que vale a pena ocupar-se dela. Meu senhorio (proprietário), um velho dos tempos de ermolovski, o cossaco velhaco e brincalhão Iapichka ${ }^{89}$, chamou-o Marka em virtude de que, como ele fala, há três apóstolos: Luka, Marka e Nikita o Mártir ${ }^{90}$ e que um ou outro dão na mesma (tanto faz). Por isso, apelidou Lukachka Marka e o nome dele se espalhou por toda a stanitsa: Marka.

Marka é um homem de uns 25 anos, de estatura baixa e aleijado. Tem uma perna desproporcionadamente pequena em relação ao tronco e a outra desproporcionadamente pequena e torta em comparação com a outra perna. Apesar disso, ou antes por isso, ele anda rápido o suficiente para não perder o equilíbrio com as muletas e até mesmo sem elas, apoiando um pé quase na metade da planta e o outro na própria ponta. Quando ele se senta, você diria que ele é um homem de estatura média e bem proporcionado. É notável que os pés dele sempre tocam (alcançam) o chão como se não estivesse sentado em uma cadeira alta.

Essa particularidade de sua postura sempre me surpreendeu. Primeiro eu relacionei as capacidades de esticamento dos pés mas, depois de estudá-lo em seus detalhes, achei a causa da inusual flexibilidade da coluna vertebral e da capacidade da parte posterior de tomar todo tipo de formas. Pela frente parecia que ele não estivesse sentado na cadeira senão que apenas se apoiasse e curvasse para colocar a mão no encosto da cadeira (essa é sua posição favorita). Mas, ao observá-lo por trás, para a minha surpresa, eu concluí que ele satisfaz por completo a exigência de estar sentado.

$\mathrm{O}$ rosto dele não é bonito. A cabeça, pequena, com corte liso à cossaca, a testa inteligente, sobressai bastante, por baixo da qual assomam uns olhos brincalhões, cinzas e não carentes de fogo. O nariz, com a ponta inclinada para baixo destaca os lábios grossos e o queixo coberto de uma barbicha ruiva de cabra. Eis os traços do seu rosto por separado. A expressão geral de todo o rosto é de alegria, presunção, inteligência e timidez. Descrevê-lo

\footnotetext{
${ }^{89}$ Iapichka ou melhor Iepichka é Epifan Sekhin, velho cossaco (гребенской) da stanitsa Starogladkóvskaia. É o protótipo de Erochka na novela Os cossacos.

${ }^{90}$ Nikita o Godo ou o Mártir foi um dos principais evangelizadores da região norte do Mar Negro. Morreu martirizado e suas relíquias estão em Kosovo. É venerado pelas igrejas Ortodoxa e Católica. (Informação disponível em http://es.wikipedia.org/wiki/Niquita el Godo . Último acesso, 17/02/2009).
} 
moralmente não posso mas todo quanto ele expressou na seguinte conversa, eu comunicarei. Já antes houve entre nós relações e conversas. Nesse mesmo dia ele tinha vindo à minha casa quando eu estava arrumando as coisas para a viagem de amanhã.

Veio ter comigo Iapichka, a quem ele teme, como muita justeza; supõe que Iapichka vai ter inveja de tudo aquilo que eu darei a Marka. Eu escolhi Marka como meu professor de língua cumuca ${ }^{91}$. Tenho, Vossa Excelência (Ele ama usar esta frase parasita), se me permite dizer, um pedido". "Que coisa"; "Depois de dizer permita-me e, além do mais -disse ele refletindo de novo e desta vez sorrindo e olhando para Iapichka- se tivesse um lapizinho e papelzinho, eu poderia por escrito...”. Eu lhe mostrei tudo quanto era necessário para a carta encima da mesa. Ele pegou o papelzinho, cruzou dobrou as pernas e as muletas, sentou-se no chão e inclinou a cabeça para um lado, molhando o lápis incessantemente, sorria e com grande trabalho (esforço) [...] em cinco minutos recebi a seguinte missiva, como é natural, torta e escrita por completo, que me entregou e, dirigindo-se a Iapichka, disse: "Olha aqui, tiozinho, estás aqui sentado mas não sabes o que está escrito". "Sim, sabidinho!". Respondeu ironicamente. "Tomo o atrevimento de pedir-lhe, Vossa Excelência, que se Vossa Senhoria vai, isto é, no que se refere ao samovar, de viagem e pronto para servir-lhe por antecipado, se ele é velhinho e a necessidade não o exige". E com o sorriso com que eu lhe disse "ta bom, pega", ele, com certeza, foi tomado pelo seu talento literário porque respondeu com aquele mesmo satisfeito e astuto sorriso com o qual tinha se dirigido antes a Iapichka. Isso é tudo.

À noite, travamos a seguinte conversa. "O senhor ainda não deseja descansar?”. "Não, não bebi. E tu, onde estavas?". "Para falar a verdade, também não estava com vontade de dormir, dei um passeio pela stanitsa, passei por algum lugar e eis que fui pra casa". Deve notar-se que ao chamá-lo e começar a conversa eu tinha um objetivo secreto- (saber se) poderia ele ser meu Mercúrio e encarregar-se desse assunto que, apesar que eu sabia que ele gostava, não podia chamar diretamente pelo seu nome. Eu tenho a particularidade de que as

91 (Los cumucos (en cumuco: къумукълар, qumuqlar, en ruso: кумыки, kumiki) son un pueblo túrquico que vive en las repúblicas rusas de Daguestán (donde comprenden el 14\% de la población [365,8 mil personas]), Osetia del Norte (distrito de Mozdoksky) y Chechenia (en el norte). Hablan el idioma cumuco y practican el

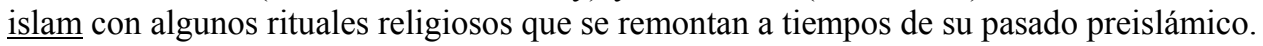

Los cumucos son descendientes de los cumanos que se mezclaron con los pueblos túrquicos que se asentaron con anterioridad a ellos en el norte del Cáucaso. ${ }^{1}$ En cuanto a sus rasgos físicos, estos son típicamente caucásicos. $)^{2}$

Último acesso, 13/02/09, http://es.wikipedia.org/wiki/Cumuco ) 
coisas que faço não por paixão mas premeditadamente, não posso, contudo, decidir-me a chamá-las pelo nome e ir direto a elas. Em sua conversa há aquela particularidade, que ele tem de ter duas formas de falar. Uma habitual que usa em casos não determinados por nada em particular e particularmente agradável. Nesse tipo de circunstâncias ele é bem-educado (se comporta com muita simplicidade e decência). Já se o discurso toca alguma coisa que sai do trilho dos seus costumes, então ele começa a falar de forma extravagante e incompreensível, não tanto quanto às palavras como aos períodos. Nessa situação, até o aspecto dele muda por completo: seus olhos ganham um brilho desacostumado, um sorriso inseguro lhe entorta a boca, o corpo inteiro se mexe e está fora de si. A conversa e relato de Marka é muito divertido, em especial sua solicitação (diante de) K. L. ... que era "muito fiel" a ele e quem, tendo atingido o objetivo desejado, não pôde aproveitar-se das dificuldades (dos trabalhos) de Marka por causa da fraqueza da saúde.

22 de Agosto. 28 será meu aniversário. Completarei 23 anos. Gostaria de começar a viver, a partir desse dia, de conformidade com o objetivo que eu próprio me estabeleci. Amanhã meditarei bem sobre tudo. Agora começarei de novo o diário com o futuro horário das atividades e o sumário da tabela de Franklin. Eu supunha que este pedantismo me prejudicava, mas o defeito não está nisso e nenhuma tabela pode estreitar os largos movimentos da alma. Se essa tabela pudesse agir em mim, então ela só é útil para fortalecer o caráter e acostumar-me à atividade. Por isso continuo com aquela mesma ordem.

Desde a saída do sol, ocupar-me de pôr em ordem os papéis, as contas, os livros e as atividades. Depois, ordenar os pensamentos e começar a reescrever o primeiro capítulo do romance. Depois do almoço (comer pouco), língua tártara, desenho, tiro, exercício e leitura.

4 de Setembro. Veio ter comigo meu irmão com Balta ${ }^{92}$ no dia 27 . No 28 , completei 23 anos. Esperava muito nessa época mas, infelizmente, fiquei igual em tudo; em poucos dias consegui fazer tudo o que não justifico. As mudanças abruptas não são possíveis. Tive mulheres, fui débil em muitas ocasiões: nas relações simples com as pessoas, no perigo, no jogo de cartas e tudo possesso pela mesma falsa vergonha. Menti muito. Fui, sabe Deus para

\footnotetext{
${ }^{92}$ Balta Isaiev, grande amigo tchetcheno de Tolstói (Nota da edição espanhola).
} 
que, a Gróznaia ${ }^{93}$. Não fui a casa de Bariatínski ${ }^{94}$. Além disso, perdi tudo o que tinha no bolso e quando voltei,no dia inteiro, não pedi a Aleksieiv o dinheiro, tal como queria. Fui muito preguiçoso (estive com muita preguiça) e agora não posso concentrar os pensamentos e escrevo, mas não quero escrever.

1851. 29 de Novembro. Tbilisi (Tíflis) ${ }^{95}$. Eu nunca tenho estado apaixonado pelas mulheres. Somente experimentei um forte sentimento parecido com o amor quando tinha 13 ou 14 anos, mas [não] quero acreditar que isso fosse amor porque a amada era uma criada gorda certo que de carinha linda; além disso, dos 13 aos 15 anos é o período de mais desordem para o menino (a adolescência): não sabes para onde atirar-te e a voluptuosidade, nesta época, age com força extraordinária.

Eu me apaixonei por homens com muita freqüência. O primeiro amor foram os dois Púshkin; depois, $2^{\circ}$, Saburov; depois, $3^{\circ}$, Zybin e Diakov; $4^{\circ}$, Obolenski, Blosfeld, Islavin e ainda Gote e muitos outros. De todas essas pessoas, só continuo a amar Diakov. Para mim, o principal indício do amor é o medo de ofender ou não agradar o ser amado, simplesmente medo [...] Todas as pessoas que tenho amado sentiram isto e eu notei que para elas era difícil olhar para mim. Amiúde, ao não encontrar no ser amado aquelas condições morais que a razão exige ou depois de alguma coisa desagradável com ele, eu senti aversão por elas. Mas essa aversão estava fundamentada no amor. Eu nunca senti esse tipo de amor pelos meus irmãos. Eu tenho tido ciúmes das mulheres com muita freqüência. Eu entendo o ideal do amor como o sacrifício absoluto de si próprio pelo ser amado. E eu senti justamente isso. Eu sempre amei as pessoas que eram frias comigo e apenas me estimavam. Quanto mais me faço velho (envelheço), tanto menos experimento esse sentimento.

A pintura age sobre a capacidade de imaginar a natureza e sua esfera é o espaço. A música age sobre a faculdade de imaginar os sentimentos e sua esfera são a harmonia e o tempo. A poesia age sobre a capacidade de imaginar tanto uma coisa como a outra, isto é, tanto a realidade como a relação dos nossos sentimentos com a natureza. A transição da pintura para a música é a dança. Da música para a poesia são as canções. Por que os antigos chamaram imitativa a música? Por que não se vincula algum sentimento a cada transição? Por

\footnotetext{
93 Gróznoie ou Gróznaia é uma fortificação construída em 1818 pelo general Alexei Ermolov na margem esquerda do Sunja, afluente do rio Terek. Com o tempo, a fortificação seria uma importante base militar para a conquista da Tchetchênia (Nota da edição espanhola).

${ }^{94}$ Alexandr Ivánovitch Bariatínski, comandante no Cáucaso (Nota da edição espanhola).

${ }^{95}$ No dia 1 de novembro de 1851, Tolstoi chega a Tíflis com seu irmão Nikolai para a legalização da sua admissão no serviço militar. Ele permaneceu lá até 12 de janeiro de 1852 .
} 
que a música age sobre nós como a lembrança? Por que conforme a idade e a educação os gostos são diferentes? O porquê a pintura é imitação da natureza é muito claro (ainda que ela não seja perfeita), mas o porquê a música é imitação dos nossos sentimentos e qual é a afinidade entre cada transformação do som e algum sentimento, é impossível de dizer. A natureza está sujeita aos nossos cinco sentidos, mas sentimentos como o desespero, o amor, o êxtase dentre outros e suas nuanças não só estão sujeitos aos nossos cinco sentidos senão que nem sequer estão sujeitos à razão. A música possui ainda, diante da música, a seguinte vantagem: a imitação dos sentimentos pela música é mais plena que a imitação pela poesia, mas não possui aquela clareza que constitui o atributo da poesia.

A liberdade consiste na ausência de coação para fazer o mal. Se a liberdade é compreendida dessa forma, então é claro que ela possua esta qualidade. Não há liberdade absoluta mas, mais ou menos provém de um maior ou menor poder e tentação em razão inversa. Eu admito o poder do destino só naquilo que não tem relação com o bem e o mal interior. Nenhuma disposição do homem pode obrigar a ser bom ou mau.

Com o poder do destino quero dizer: O que não pode evitar-se será. “Sim, será a tua vontade!".

Todos os átomos têm forma esférica e giram ao redor de seu eixo. A lei da gravitação é a lei das forças centrífuga e centrípeta. O sentido do tato provém da fricção dos átomos em circulação. O tato existiria mesmo que não houvesse pressão. Quanto menor a pressão, mais claro o sentido do tato.

22 de dezembro de 1851. Tive um estranho sonho sobre Mítenka. No dia 21 de dezembro deste mesmo ano, às 12 da meia-noite tive algo parecido a uma revelação. Para mim foi clara a existência da alma, a sua imortalidade, a dualidade da nossa existência e a essência da vontade. A liberdade é relativa. Em relação à matéria, o homem é livre, em relação a Deus, não.

Hoje, 22 de dezembro, acordou-me um sonho terrível: o cadáver de Mítenka. Foi um desses sonhos que não se esquecem. Será que significa alguma coisa? Depois chorei muito. Os sentimentos são mais exatos no sonho do que na realidade. Os falsos racionamentos suscitam um sentimento poético. 
1852. 2 de janeiro. Quando eu buscava a felicidade, eu caía no vício. Quando eu entendi que nesta vida só é suficiente não ser infeliz, então as tentações no meu caminho se tornaram menos viciosas e eu estou convencido de que é possível ser virtuoso mas não ser infeliz.

Quando eu buscava o prazer, ele se afastava de mim e eu caía em um terrível estado de tédio do qual se pode passar para todo o bom ou mau e mais rapidamente para esse último. Agora, quando apenas me esforço em correr do tédio, em tudo acho o prazer.

Para ser feliz é necessário fugir da infelicidade; para que fosse alegre é necessário fugir do tédio. Tout vient à point à celui qui sait attendre*.

Platão diz que a virtude consiste em três qualidades: a justiça, a moderação e a coragem $^{96}$. A justiça é, parece-me, a moderação moral. Seguir no mundo físico a regra: nada de excessos, será a moderação e no mundo moral será a justiça. A terceira qualidade de Platão só tem uma forma de conformar-se à regra nada de excessos: a força.

Todas as pessoas jovens têm uma época em que não possuem nenhuma ideia firme das coisas, isto é, das regras, e criam tanto umas como as outras. Nesta época, eles evitam os interesses práticos e vivem no mundo moral. Eu chamo esta época de transição - juventude. Em certas pessoas, a juventude se prolonga mais, em outras, menos. Inclusive, há pessoas que permanecem sempre jovens e outras que nunca foram jovens. Do que depende a prolongação desta época? Pareceria, tal como eu disse, que nesta época as pessoas jovens ocupam-se da formação das ideias firmes sobre as coisas e das regras. Quanto mais inteligente for o homem jovem, mais rápido deverá passar esta época: ele se estabelecerá regras e viverá em conformidade com elas. Mas, na realidade, acontece completamente ao contrário. O lado prático da vida, quanto mais nos movimentamos em direção a ele, exige nossa atenção mais e mais. Mas quanto mais tem o homem inclinação para a reflexão (e por isso encontra nela o deleite moral) tanto mais se esforça ele em afastar dele o período desta transição. E para formar-se uma noção exata das coisas e estabelecer-se regras para a vida não é suficiente um

\footnotetext{
* Tudo chega a tempo àquele que sabe esperar (Em francês no original).

${ }^{96}$ Platão manifestou esta ideia no diálogo "O político". Tolstói o leu na tradução para o francês.
} 
século inteiro de reflexão. Embora ele se encontre nesse caminho e vá enfrente, a necessidade exige deixar de estabelecer regras mas, agir em conformidade com aquela que não teria sido estabelecida ainda.

Por isso, todos nós, ao entrarmos na vida prática começamos a agir com base naquelas imperfeitas e intermináveis regras e noções nas quais nos encontrou a necessidade.

A duração desse período demonstra inteligência, mas não contribui para realização na vida prática. É mais fácil agir com base em regras simples, sem complicações ainda que incorretas mas em concordância com as próprias regras que já adotei sem tê-las compreendido, do que agir conforme regras que podem ser corretas mas que não foram suficientemente esclarecidas e levadas à unidade. Daí que os tolos triunfem mais no mundo do que as pessoas inteligentes.

Duas observações para escritor belles-lettres*. A sombra, ainda se projeta na água, muito raramente pode-se vê-la e, quando a vemos, então ela não espanta em absoluto.

Cada escritor considera, na sua composição, uma categoria especial de leitores ideais. É necessário determinar-se claramente as exigências destes leitores ideais e se, na realidade, existem em todo o mundo nem que seja dois desses leitores, deve-se escrever só para eles. Ao descrever indivíduos ou paisagens incomuns para a maioria dos leitores, nunca esquecer os indivíduos e paisagens comuns: tomá-los como base e, em comparação com eles, descrever os incomuns.

\section{Primeira canção Tchetchena de Balta ${ }^{97}$}

1 de fevereiro de 1852. Starogladkóvskaia.

Su saina tekhna mirera kakhbe kachdako babaei erik datsekh

Eu me mataria se, quando fossem cavar-me a sepultura, as pessoas não dissessem que sou uma puta.

\footnotetext{
* beletrista (em francês no original).

${ }^{97}$ Como já foi dito, Tolstói introduzia no seu diário pequenos textos de natureza diversa. Aqui coloca duas canções tchetchenas. Seguindo o formato do texto original em russo, o primeiro verso é transliteraçao da canção seguida pela tradução.
} 
Su eda hkoriera ara nakha kakhbe lior lakho nahke bekher datsear

E se eu corresse para o campo - que fui procurar as pegadas das putas, diriam as pessoas

Tsiguel erier daokhilli uokha ilitchen tsaka erikhar

Se eu voasse para o céu - temeria descer como chuva

Soukhoelkhatchi tsukkeriu tsuni ka kheikarda keriu

Se descesse como chuva, temeria que com ela crescesse o cereal

So latykh khoriera butskhelle khalielerna tsakirakh

Eu entraria na terra, mas de crescer como a erva tenho medo

Otsekanti chinstare earenakeriu otsekant ere iale metetchatson

Meu noivo é uma junta de bois, temo que eles me comam. Não há como fugir do meu noivo.

2da canção tchetchena de Sado

Alalu vadadai chliuka chai-ina baba vai-anni

Ai, aai, aiaiai! Que desagradável, querida mamãezinha,

Bajelera siots onachle $i$ khunda baleina khai khun

Para que trouxeram para a estrebaria de tábuas o belo cavalo, não sabes tu?

Vai da da daí! Vaim bertchir ardjemajer i khunde

Aiaiai aiai ai, de quem é o fuzil da Criméia, pendurado na parede?

Eina khasch khun? Kho lakho voutchu guiurdji ele eina

Para que o trouxeram, tu sabes? Veio pedir a tua mão um Príncipe georgiano; ele é que o trouxe.

Sa nana seideguo tetse eudo assainda lakhna buisinakh de den kant

Mamãezinha! Meu coração não quer saber dele. Eu própria achei um bravo jovem que me faz da noite dia.

Vadadai baba vaimbertchire guiurdjindari i khunda

Mamãezinha, há uma seda de Tíflis ${ }^{98}$ na parede, para que ela está pendurada aqui?

Diana khamkhun. Khaekhunvoutchu. - Ka te da aichike

Trouxe-a quem pede a tua mão.

Suona vieza Guiurjiekh iukhuch darioch kiekhankant

Eu não gosto dos noivos que vão à Geórgia em busca de mercadorias

\footnotetext{
${ }^{98}$ Tíflis é o nome antigo de Tbilíssi, capital da Geórgia (N. de T.).
} 


\section{Sa nana seigurtekha maiaka so khaina ezakh}

Mamãezinha, se tu me amas, não acabes com a minha vida

Buisanakh dedina Kant via iuioltch, march

Aquele que me faz da noite dia veio a mim. Adeus,

Sila sonana duka kereakhso so khuntse iuada Maria

Mamãezinha, tu me aterrorizaste, agora vou casar-me

Dala mukalo khuntsikh so sai kurten iukkhu eele

Graças a Deus, agora a minha alma está livre.

5 de fevereiro de 1852 (Nikoláievka ${ }^{99}$ - vou com o destacamento). Sou indiferente à vida, na qual tenho sentido demasiado pouca felicidade para amá-la; por isso, não temo à morte e também não temo os sofrimentos. Mas temo não saber suportar nem os sofrimentos nem a morte. Não sou calmo em absoluto. Noto isso porque passo de uma disposição de espírito para outra ao considerar muitas situações. É estranho que minha percepção infantil -a intrepidez, bravura- da guerra é para mim a mais tranqüila. Em muitos aspectos eu volto à visão infantil das coisas.

Ano 1852, 28 de fevereiro. No destacamento (perto de Teplikitchu ${ }^{100}$ ). Na realidade, nunca tenho justificado as esperanças da minha imaginação. Eu desejava que o destino me colocasse em situações difíceis para as quais fosse necessária a força da alma e a virtude. A minha imaginação gostava de figurar-me essas situações e um sentimento interior me dizia que me alcançariam a força e a virtude para elas. Meu amor-próprio e a segurança nas forças da minha alma cresceram sem achar contestação. Os acontecimentos nos quais eu poderia ter justificado minha segurança, mas não a justifiquei, eu me desculpei em que me representaram muito poucas dificuldades e em que eu não utilizei todas as forças da minha alma.

Eu fui orgulhoso, mas o meu orgulho não se baseava nos fatos mas na firme esperança de que sou capaz de tudo. Por isso, meu orgulho externo não possui segurança, firmeza e constância; eu, da arrogância extrema passei para a modéstia excessiva.

O meu estado no momento de perigo abriu-me os olhos. Eu gostava de imaginar-me como absolutamente de sangue frio e calmo no perigo. Mas nos acontecimentos dos dias 17 e

\footnotetext{
${ }^{99}$ Stanitsa Nikoláievskaia, localizada na margem esquerda do Terek.

${ }^{100}$ Fortificação na margem esquerda de Sunja mais próxima da fortificação de Grózni.
} 
$18^{101}$ eu não fui assim. Não tive os pretextos, que eu usava com freqüência, de que o perigo não era tão grande assim como eu imaginava. Esta foi a única oportunidade de mostrar toda a força da minha alma e fui fraco e por isso estava insatisfeito de mim.

Só agora entendi que a segurança nos fatos futuros é ilusória, que se pode ter esperanças em si próprio só naquilo que já se viveu. Que a segurança aniquila a própria força e que não se deve considerar nem um só acontecimento como insignificante para aproximarse dele com todas as forças.

Em uma palavra, não deixar para amanhã o que se pode fazer hoje.

Como não é simples esta regra, como não raro eu a escutei, e a entendi e reconheci sua verdade apenas agora.

Existe só um caminho certo pelo qual o pensamento pode converter-se em convicção.

20 de Março de 1852. Starogladkóvskaia. Agora reli meu velho diário de julho do ano 1851 e alguma coisa escrita neste livro, o prazer que me provocou essa leitura, obriga-me a continuar o diário para, no tempo futuro, preparar-me esse mesmo prazer. Alguns pensamentos escritos neste livro me surpreenderam, uns pela sua originalidade, outros pela sua exatidão. Parece-me que já perdi a capacidade de escrever e pensar tão corajosa e vivamente. É verdade que esta coragem está frequentemente vinculada ao paradoxo, mas, por isso mesmo, a uma maior confiança* .

É preciso confessar que uma das mais importantes ambições da minha vida era convencer-me de algo de maneira firme e constante. Será que com os anos as dúvidas crescem? Nos diários achei muitas lembranças agradáveis - mas agradáveis só porque eram lembranças. Durante todo o tempo em que escrevi o diário, fui muito malcomportado, meu rumo foi o mais enganoso. Daí que de todo esse tempo não há nem um minuto que eu deseje fazer voltar

\footnotetext{
${ }^{101}$ Nos dias 17 e 18 de fevereiro houve combates com os montanheses no rio Mitchik. Um projétil atingiu uma roda do canhão que Tolstói conduzia.

* Agora, comecei a ter preguiça de pensar e convencer-me de alguma coisa. Contudo, nem acredito nem duvido menos do que antes. Equilíbrio em tudo. Comecei a ter preguiça de convencer-me porque também estava cansado de mudar de parecer e guardo com zelo essas crenças que minha agitada razão deixou em paz e temo decepcionar-me delas e até pensar nelas (Nota ao margem feita por Tolstói).
} 
tal qual como foi e todas as mudanças que eu gostaria de fazer, gostaria de fazê-las em mim próprio.

Minhas melhores lembranças estão relacionadas com a adorável Volkónskaia ${ }^{102}$.

Em todo o diário é evidente uma ideia principal e um desejo: livrar-se da vaidade que me oprimia e estragava todos os deleites e a busca dos meios para livrar-me dela.

Deixei de escrever o diário já durante quase 7 meses. Passei setembro em Starogladkóvskaia, isto é, nas viagens para Grózni e Staryi Yurt. Fui de caça, arrastei-lhe as asas as filhas dos cossacos, bebi, escrevi um pouco e traduzi. No mês de outubro, fui com meu irmão a Tíflis para a nomeação no serviço. Em Tíflis, passei o mês indeciso: o que fazer e com tontos e vaidosos planos na cabeça. Desde o mês de novembro estive em tratamento fiquei dois meses inteiros, isto é, até o ano novo, em casa. Passei este tempo, embora enfastiado, tranqüila e proveitosamente - escrevi toda a primeira parte ${ }^{103}$.

Passei janeiro, uma parte no caminho, uma parte em Starogladkóvskaia; escrevi, aperfeiçoei a primeira parte, preparei-me para a campanha e estive calmo e bem. Passei fevereiro na campanha; estive satisfeito de mim. No começo de março fiz o jejum, enfastieime e tive preguiça. Ao partir para a campanha, eu, até tal ponto tinha me preparado para a morte, que não só larguei senão que me esqueci das minhas ocupações anteriores; assim, agora é mais difícil para mim do que em outro momento, dedicar-me a elas de novo.

Embora neste tempo tenha pensado muito pouco em mim, a ideia de que me tornei muito melhor do que era antes se me enfiou na alma - incluso tornou-se uma convicção. Realmente terei eu me tornado melhor? Ou será apenas essa arrogante segurança na minha emenda, que sempre tive, quando me tracei por antecipado um estilo de vida futuro?

Quanto pude conhecer-me, parece-me que em mim predominam três paixões: o jogo, a volúpia e a vaidade. Já há tempos eu tinha me convencido de que a virtude, inclusive no grau mais alto, é a ausência das más paixões. Por isso, se realmente aniquilei em mim, nem que seja algumas paixões predominantes, eu posso dizer sem medo que me tornei melhor.

\footnotetext{
${ }^{102}$ L.N. Volkónskaia.

${ }^{103}$ Primeira parte do romance Quatro épocas do desenvolvimento - Infância, (seguda redação).
} 
Examinarei cada uma destas três paixões. A paixão pelo jogo deriva da paixão pelo dinheiro mas, em maior parte (principalmente naquelas pessoas que perdem mais do que ganham), uma vez que se começa a jogar, por não ter nada que fazer, ela deriva da imitação e do desejo de ganhar; elas não possuem paixão pelo lucro mas adquirem uma nova paixão pelo próprio jogo: pela sensação. A fonte desta paixão está, consequentemente, no costume e o meio de aniquilar a paixão é aniquilar o costume. Eu fiz assim. A última vez que joguei foi em fins de agosto, portanto, [há] 6 meses e pouco, e agora não sinto nenhuma vontade de jogar. Em Tíflis eu comecei a jogar uma partida com o marcador e perdi qualquer coisa perto de mil partidas. Nesse minuto poderia tê-lo perdido tudo. Portanto, uma vez adquirido esse costume, embora não sinta vontade nenhuma de jogar, devo, porém, fugir da oportunidade de jogar já que o faço ainda que não sinta nenhuma privação.

A volúpia possui uma causa completamente oposta: quanto mais te absténs, mais forte é o desejo. Há dois motivos desta paixão: o corpo e a imaginação. É fácil opor-se ao corpo, já à imaginação, que age também sobre o corpo, é muito difícil. O meio contra uma como contra outra causa é o trabalho e as atividades tanto físicas - a ginástica, como morais - a composição. Além disso, não há nada. Como essa inclinação é natural, e eu acho má sua satisfação só pelo fato da situação antinatural em que me encontro (solteiro aos 23 anos), nada ajudará para livrar-se das tentações, exceto a força de vontade e as orações a Deus. Tive uma mulher em setembro, no fim, e ainda em Tíflis há quatro meses.

A vaidade é uma paixão incompreensível. É um desses males com que a providência martiriza às pessoas como com as epidemias: a fome, os gafanhotos, a guerra. As fontes desta paixão não podem ser descobertas. Mas as causas que a desenvolvem são, a saber: a inatividade, o luxo e a falta de preocupações e privações.

Esta é qualquer coisa como uma doença moral parecida com a lepra: ela não destrói uma parte senão que deforma tudo. Ela, aos poucos e sem ser notada, penetra e depois se desenvolve em todo o organismo. Não há nem uma só manifestação que ela não contagie. Ela é como uma doença venérea: se é expulsa de um lado, com mais força se manifesta em outro. O homem vaidoso não conhece a verdadeira alegria, nem a aflição, nem o amor, nem o medo, nem o desespero, nem o ódio - tudo é antinatural, violento. A vaidade é um certo amor imaturo à glória, um certo amor-próprio levado à opinião dos outros: ele se ama não como ele é, mas como ele se mostra aos outros. Desta paixão, extraordinariamente desenvolvida no 
nosso século, riem mas não a condenam, porque ela não é nociva para os outros. Mas, para o homem possesso por ela, é pior do que todas as outras paixões: ela envenena toda a existência. Um traço exclusivo desta paixão, em comum com a lepra, é a extraordinária contagiosidade. Contudo, parece-me que, ao razoar sobre isto, descobri a fonte desta paixão: é o amor à glória.

Eu tenho sofrido muito por causa desta paixão. Ela estragou os melhores anos da minha vida e levou de mim para sempre toda a frescura, coragem, alegria e o espírito empreendedor da juventude.

Não sei como, mas eu a reprimi e até incorri no extremo oposto: eu me guardo de cada manifestação, medito com antecedência, com o temor de reincidir no erro anterior. Não sei se o acaso ou a providência fizeram com que esta paixão raras vezes fosse satisfeita, de forma que eu experimentasse só um sofrimento que ela provocou, ou a influência do meu irmão, que quase não entende o que é a vaidade, ou o afastamento do círculo da vaidade e o estilo de vida que me forçou a ver a minha situação desde uma perspectiva séria, eu só aniquilei por completo essa paixão no tempo da minha doença em Tíflis.

Não posso dizer que essa paixão tenha sido completamente aniquilada porque, com frequência, eu me lamentei dos deleites que ela me trazia mas, na verdade, eu compreendi a vida sem ela e adquiri o costume de afastar-me dela.

Apenas há pouco experimentei por primeira vez desde a infância o deleite puro da oração e do amor. Ainda pelo diário, a meu ver no inverno passado é evidente que eu queria destruir essa paixão. Mas eu só caí nessa manifestação que me era desagradável por não ter compreendido que é necessário arrancá-la de raiz para poder livrar-se dela. Parece-me que eu agora fiz isso. Mas eu ainda tenho uma inclinação a ela e, por isso, devo guardar-me de um novo contágio.

20 de Março. Levantei depois das 8 horas. Doeram-me muito os dentes antes do amanhecer. Em parte por preguiça, em parte pela doença, não fui ao treinamento. Li o diário antigo e escrevi o novo até o almoço. Aleksiéev é assim tão enfadonho - com aquele infindável relato de coisas das quais ninguém pode ocupar-se, pela incapacidade de escutar e o tímido e inseguro olhar. Talvez minha opinião acerca dele age e daí sinto não sei que vergonha de olhar para ele (júnker Makhin). Depois do almoço estive escrevendo, chegou 
Durda, incomodou-me; mas eu tive vergonha de expulsá-lo porque antes eu o recebia bem. Ele deve ser um astuto finório. Me contou sobre a escaramuça de Hadji-Murát com Arslan Khan sobre a mesquita ${ }^{104}$. Teria sido interessante vê-los. Por algum motivo, Durda se formou uma muito bondosa e boa opinião dos russos; e no ano passado com orgulho contava como ele batia nos cossacos.

Estranho que nem um só do monte de tchetchenos que andam no meio dos russos mostrou aqueles caminhos que mostrou Bota. E todos eles são muito cobiçosos. Quando perguntei a Durda sobre isso ele me disse que, com certeza, Bota tinha se zangado muito. Por que diabo eu contei a Durda que eu próprio tinha visto como Bota se acovardara com a granada sendo que eu não vi isso? Depois de estar em casa de Durda, fui ter com Ianóvitch; mas a intenção aqui era outra. Desde então, como eu encontrei Pomtchichka (talvez, não sem intenção da parte dela), com frequência ela me vem à cabeça e se me tornou mais difícil abster-me. Em casa de Ianóvitch estava um júnker, mas ele me desagradou tanto que eu, ao vê-lo, nem entrei no quarto. Quando saí com Ianóvitch eu ria por alguma coisa e fiquei, como diz Nikólenka, com vontade de jogar golychka ${ }^{105}$. Queira Deus que essa disposição de espírito venha com mais freqüência. Há muito que eu não estava tão contente como hoje e isso foi porque trabalhei. Quanto proveito, parece, há no trabalho; e na preguiça, nem utilidade nem prazer e, contudo, ela prevalece.

Agrada-me tanto Ianóvitch, sua bondosa e franca modéstia, que em uns quantos dias me acostumei a ele como a um velho conhecido. Joguei com ele xadrez, distraída e apressadamente, fiz ginástica antes de estar em presença de Sulimóvski. Depois, não sei por que diabo, chamei Dmitri e ri dele. Isso foi estúpido. Ainda joguei algumas partidas de xadrez, também mal, e Ianóvitch veio jantar e eu sentei para escrever cartas a Valerian e Andrei. Eu estava redigindo essas cartas quando recebi a carta de Andrei. Depois, fiquei bravo e pareceume muito bem. Já agora, pelo contrário, estou em boa disposição de espírito. E da união destas duas disposições de espírito saíram as cartas que não me agradam. O despeito e as expressões são absolutamente femininos. Li Thiers ${ }^{106}$ e vou dormir às $11 \mathrm{e} 1 / 2$.

\footnotetext{
${ }^{104}$ Primeira menção aos episódios que se encontram mais tarde representados na novela Hadji-Murát (1904).

105 A palavra "golychka" provavelmente provenha da palavra "golych" que significa nu. Pode fazer referência a um brinquedo, comumente uma boneca sem roupa ou a uma pedra que se tornou muito lisa por efeito da fricção da correnteza. Tolstói deve referir-se aqui a algum jogo com pedras desse tipo (N. de T.).

${ }^{106}$ Tolstói estava lendo a obra de Louis Adolphe Thiers História da revolução francesa, Paris, 1823 - 1827.
} 
Amanhã vou levantar-me mais cedo e esforça-me por ter um dia o mais cheio possível. Maldita preguiça! Como eu seria um homem bom se ela não me atrapalhasse. Eu me preocupo e sinto saudades do meu irmão. Só me vêm maus pensamentos à cabeça sobre isso.

21 de Março. Levantei-me depois das 7 horas, li o capítulo de Thiers na hora do chá. Depois dei uma caminhada com Dmitri e os cachorros. O que foi bastante estúpido da minha parte, porque teria sido melhor ir aos exercícios e, ainda absolutamente melhor, não ir, porque, de novo, fiquei no frio até congelar-me os dentes ${ }^{107}$. Não cacei nada, cheguei em casa e traduzi até o almoço. Durante o almoço, falei sobre os incêndios com Khilkóvski, suficientemente bem. Bom velho! - simples (no bom sentido da palavra) e corajoso. Destas duas qualidades estou seguro. E além do mais, seu aspecto exterior não exclui, como o aspecto exterior de Sulimóvski, tudo o que é bom. Aleksiéev estava ocupado com o feno e olhar dele era severo. Eu estou completamente convencido de que a vaidade provém da inatividade física e moral. Depois do almoço, reescrevi a primeira parte ${ }^{108}$ e trabalhei sem qualquer coação. Queira Deus que isto seja sempre assim! Chegou Sultánov, em êxtase por ter conseguido um cachorro. Notável e original personalidade. Se ele não tivesse paixão pelos cachorros, ele seria um canalha rematado. Esta paixão concorda, mais do que nada, com a sua natureza.

Ao chegar meu irmão, eu lhe contei como foi desagradável para mim escrever as mentiras que me exigiram sobre a retirada ${ }^{109}$, com a esperança de que ele me tranquilizasse completamente sobre esse assunto, dizendo-me que isso é uma ninharia; pelo contrário, ele achou que eu fiz mal. Estranho como ele, com suas cavalheirescas regras de honra, às quais sempre é fiel, pode acostumar-se e ainda achar prazer entre os oficiais locais. De onde será que há entre nós não sei que embaraço desde quando eu cheguei de Tíflis? Será que não é pelo fato de amar-nos tanto, que idealizáramos um ao outro na ausência e esperamos demasiado um do outro?

\footnotetext{
${ }^{107}$ Existe em russo a expressão "prostudit zuby" que significa, ao pé da letra, resfriar-se os dentes. É o nome com que se conhece uma afecção dos dentes caracterizada por dor intensa devida à exposição ao frio extremo. Os efeitos do "congelamento" podem ser muito graves e levar até a perda dos dentes comprometidos (N.de T.).

108 Começo do trabalho da terceira redação de Infância.

109 Otzyvom (do russo ótzyV, retirada) era, naquela época, o nome de qualquer resposta oficial aos requerimentos da instituição oficial. Neste caso, entende-se ser o documento da demissão de Tolstói do serviço na província de Tula, sem o qual não poderia ter sido inscrito no serviço militar. Em que consistem as "mentiras sobre a retirada" não pôde ser estabelecido.
} 
Ordem nas tarefas que assumi, isto é, pela manhã, tradução, depois do almoço, correção e à noite, a novela ${ }^{110}$; muito bem. Só não sei quando fazer ginástica e isso é, com certeza, necessário - algum exercício cada dia. Agora são 10 e pouco, estou jantando e logo vou me deitar.

Quando trabalhas, o tempo passa tão depressa que gostarias de pará-lo. Na ociosidade, ele passa tão lentamente que gostarias de enxotá-lo. O que é mais prazeroso? É difícil de determinar. Somente sei que, nas lembranças, um dia passado nas tarefas equivale a três ociosos. Por esse cálculo, nos dias ociosos o tempo deveria passar mais rápido, mas acontece o contrário.

22 de Março. Levantei-me depois das 9 horas porque à noite me doeram os dentes, tão forte que eu, meio adormecido, soltava ais e dava gritos. Bebi dois copos de café para resistir a cânfora que eu engoli muito por causa da dor de dentes e, depois disso, transpirei a manhã inteira. Chegou meu irmão e Ianóvitch. Eles me atrapalharam um pouco mas eu continuei a traduzir. Almocei em casa; depois do almoço, fiquei um pouco preguiçoso; embora tenha trabalhado, não com tanta diligência como ontem. Convenci-me de que a cânfora não aniquilou as forças genitais.

Fiz as correções, não tantas como ontem e nem com tanto esmero; mas o principal é que não me aborreci do trabalho. Perdi duas partidas de xadrez para Ianóvitch: sem a rainha. E nisso é evidente como ele é modesto. Não continuei a novela em parte porque não tive tempo, em parte porque começo a duvidar seriamente do mérito da primeira parte. Parece-me demasiado detalhada, extensa e pouco viva. Pensarei nisso.

A volúpia começa a tornar-se mais forte. É preciso ser cuidadoso. Quase não fiz nenhum exercício. Não se deve sair de casa, mas em casa é enfadonho. Agora são 11:30. Vou me deitar. Estou satisfeito com o dia de hoje.

23 de março. Levantei-me às 7. O tempo estava tão bonito. Estive de caça, até 1 hora. Matei dois patos. Atrasei-me para o almoço e jantei em casa. Depois do almoço vieram Khilkóvski e Ianóvitch para fazer ginástica. Khilkóvski me agrada muito, mas ele me faz sentir incômodo; é para mim constrangedor olhar para ele, como é constrangedor olhar para as

\footnotetext{
${ }^{110}$ Tolstói continuava Infância e corrigia já a escrita de um capítulo.
} 
pessoas por quem estou apaixonado. Foi recebido o papel de minha aceitação. Eu, sabe-se lá por quê, não faço bem a ginástica. Khilkóvski me envergonhou, sobre tudo por ele ter ser precipitado. Depois da ginástica, joguei duas partidas de xadrez e dormi tão bem até umas 9 horas e fui jantar. Aleksiéev não está. Ele foi embora para Kizliar. Por isso jantar não foi enfadonho. Depois do almoço fui com meu irmão e Ianóvich para a casa de Khilkóvski e dai para a casa. Por algum motivo Nikólenka andava alegre demais e confesso que para mim não era agradável olhar para essa alegria dele porque ele parece um alegre bobo e sem sentido. Pela manhã eu ainda estava indeciso - trabalhar ou não no domingo. Deu que, mesmo que eu quisesse, não teria conseguido trabalhar ontem; até não conseguir escrever o diário e o escrevo hoje, 24, às 8 da manhã. Por isso decidi da agora para sempre que aos domingos e grandes feriados serão dias de descanso.

24 março. Levantei-me as 7. Terminei de escrever o diário de ontem. Bebi chá e li. Traduzi até as 11 . Às 12 fui de caça no potro que peguei do meu irmão. Cheguei perto do almoço à casa do Aleksiéev que ainda não tinha chegado. Foi muito desagradável para mim estar sem farda e eu temia, como uma criança, que Aleksiéev chegasse e desse uma bronca. Depois do almoço, os exercícios com tesak ${ }^{111}$, que não têm sentido nenhum, me resultaram terrivelmente repulsivos. Recebi uma carta do Serioja. Seus julgamentos e conselhos foram muito desagradáveis para mim porque me lembraram Tula. Fiz algumas correções, chegou Ianóvitch, fiz esgrima, me parece que não vamos chegar em nada. Chegou meu irmão, joguei xadrez e fui jantar. Agora são 12 e pouco, vou dormir. Amanhã é feriado, só vou fazer as correções, desde que não tenha nada melhor para fazer. Oração: Pai nosso, Nossa Senhora, encomendar meus parentes vivos e falecidos. Depois, livra-me Senhor, da vaidade, da indecisão, da preguiça, da volúpia, das doenças e do desassossego da alma. Permite que eu viva sem pecados e sofrimentos e morrer sem desespero e pavor. Entrego-me a tua vontade, com fé, esperança e amor. Nossa senhora e Anjo da Guarda, intercedam por mim ante Deus.

27 de março. Manhã. Dia 25, levantei-me às 7. Li, fiz as correções, às 11 cavalguei no potro, estive em casa do meu irmão, e encontre-me com Khilkóvski, Ianóvitch e Aleksiéev. Depois almocei. No almoço houve uma conversa sobre como é difícil fazer o bem. Comecei a sentir dor de dentes - deu que era uma inflamação na gengiva que me torturou até as 4 horas

\footnotetext{
111 Tesak é uma arma branca de lâmina curta que era dada aos soldados de infantaria e artilharia do exército russo, desde meados do século XVIII e durante o século XIX. Seu uso para fins militares foi suspenso, por não ser uma arma eficiente contra os ataques da cavalaria (N. de T.).
} 
da manhã de hoje. Ontem passei por casa do meu irmão e, do jeito simpático e engraçado dele, contou sinceramente, como esteve bêbado duas vezes - que pena! Eu me mexia, mas não me queixava. Li Otiéchestvennye Zápiski de fevereiro. Estrada vicinal, muito bom mas, pena que seja uma imitação ${ }^{112}$. Hoje vou fazer correções e, talvez, escrever.

27 de março, meia-noite. Apesar de não ter melhorado completamente, fiz correções até as 11 horas, e fiz correções não muito bem e com clareza; almocei, terminei de ler e continuei com esse mesmo trabalho; chegou meu irmão e eu li a ele o escrito em Tíflis ${ }^{113}$. Na opinião dele, não está tão bem quanto o anterior e na minha não presta nem para o diabo. Gostaria de facilitar meu trabalho. Mas os copistas não podem reescrever; portanto, é necessário trabalhar sozinho.

Por causa de um artigo de A. Dumas sobre música ${ }^{114}$, eu me lembrei do enorme deleite do qual estou privado aqui. Quase todos os sonhos de felicidade estão realmente destruídos na minha imaginação, exceto a felicidade do artista. Embora em um aspecto muito imperfeito, eu a experimentei na aldeia no ano $1850^{115}$

Amanhã vou copiar, reescrever uma carta a Serioja e pensarei no $2^{\circ}$ dia $^{116}$ : pode ele ser corrigido ou deve ser abandonado por completo?

Devem ser aniquiladas sem pena todas as passagens confusas, extensas, inoportunas, em uma palavra, insatisfatórias, embora elas sejam boas em si mesmas.

Constância e resolução. Eis duas qualidades que garantem o sucesso em qualquer empresa. Vou me deitar, doze e $1 / 2$.

28 de março. $10: 30$ da noite. Os dentes me doeram a noite inteira. Cedo de manhã chegou Nikólenka, e eu não dormi. Estivemos bebendo chá e ele foi embora de caça. E li um pouco e comecei a escrever. Escrevi pouco, sob o pretexto de estar com dor. Apesar que, na verdade, eu me sentia fraco e o tempo todo salivava, isso não foi mais que um pretexto. Eu me

\footnotetext{
${ }^{112}$ Estradas vicinais é um romance de D.V. Grigórovitch (Otiétchestvennye Zápiski, 1852, № 2 e 3).

113 Segunda redação de Infầncia.

114 Provavelmente se trate das considerações de A. Dumas sobre a música aparecidas no artigo "Viagem de Alexander Dumas por Tunísia, Marrocos e Argélia (Otiétchestvennye Zápiski, 1852, № 2).

${ }^{115}$ No verão de 1850, Tolstói estudou música intensamente em Iásnaia Poliana. São textos por ele conservados então "Método provisório para o estudo da música", "Bases do início da música e regras para o estudo autodidata". Também "regras em matéria de música" das anotações do diário de 17 de junho de 1850.

116 "O segundo dia” na novela Infầncia: a estada de Nikólenka Irtiéniev em Moscou.
} 
deitei e dormi até as 2. Depois li Anton Goremyka ${ }^{117}$, bati papo e joguei damas com os recém-chegados: Buiémski, Ladijénski e Ianóvitch. Meu irmão me perguntou se eu ia para a casa de Aleksiéev comer feijão. Eu lhe respondi com irritação. Foi uma bobagem. Trouxeram uma caixinha e fiquei com pena de enviá-la a Sado. Que bobagem. Vou enviá-la com Buiémski. É necessário afastar-se do frio e da preguiça tanto como seja possível. Vou escrever uma carta a Serioja e vou dormir.

29 de março. Levantei-me depois das 9. Não me doeram os dentes. Contudo, sob pretexto da minha fraqueza, e também porque Buiémski me atrapalhou, fiquei sem começar o trabalho por muito tempo. Às 11 chegaram Nikólenka, Ladijénski, Ianóvitch e Khilkóvski e me atrapalharam. Fiz esgrima bastante bem. Houve dois nagaitsy ${ }^{118}$. Não preciso para nada de um curandeiro. Não posso negar ao Abiliez dar amanhã $2 \mathrm{r}$. Tem que dar amanhã 1, porque em total tenho 4. Almocei e escrevi bastante pouco. Fui aos banhos e de novo chegaram os senhores.

Desde há algum tempo começou a atormentar-me o arrependimento pela perda dos melhores anos da vida. E isso desde quando comecei a sentir que eu poderia ter feito alguma coisa melhor. Haveria sido interessante descrever o processo do meu desenvolvimento moral; mas não só as palavras, senão o pensamento é insuficiente para isso.

Não há limites para o grande pensamento, mas já há tempos que os escritores alcançaram o limite lícito de sua expressão. Joguei às damas, jantei, vou dormir. Atormentame a futilidade da minha vida. Sinto que isso é assim porque eu próprio sou fútil; e, porém, tenho a força para desprezar-me e desprezar a minha própria vida. Há alguma coisa em mim que me obriga a acreditar que não nasci para ser assim como todo mundo. Mas de onde vem isso? Será da discordância, da ausência de harmonia em minhas capacidades ou será que eu, em verdade, estou por cima das pessoas comuns em alguma coisa? Sou velho. A época de desenvolvimento já passou ou está passando. E tudo o que me atormenta é a sede... não de glória, não quero a glória e desprezo-a; senão ter grande influência na felicidade e proveito das pessoas.

\footnotetext{
${ }^{117}$ Novela de Dmitri Grigoróvitch publicada em 1847 (N. de T.).

${ }^{118}$ Pequeno povo tártaro, habitante da estepe próxima a Piatigorsk.
} 
Será possível que morra com este desejo desesperado? Há pensamentos que eu não digo a mim mesmo; e os valorizo tanto que sem eles não haveria nada para mim. Eu escrevi a novela com vontade, mas agora desprezo o próprio trabalho, e eu, e aqueles que vão lê-la. Se não abandono este trabalho é só com a esperança de despachar o tédio, acostumar-me ao trabalho e comprazer Tatiana Aleksándrovna. Se envolve alguma ideia vaidosa, ela é tão pequena que eu a perdôo em mim, porque traz um proveito - a atividade.

Eu temia tanto a vaidade e a desprezo tanto que não espero que a sua satisfação me produza qualquer prazer. E é necessário esperar isso porque se não, o que mais fica - para que avançar? Amor, amizade! Sem querer, eu tomo estes dois sentimentos por paixão, engano da jovem imaginação. Será que eles me provocaram a felicidade? Mas pode ser que eu só tenha sido infeliz. Esta esperança sustenta o desejo de viver e esforça-se. Se são possíveis a felicidade e a atividade útil e eu as experimento, pelo menos estarei em condições de servirme delas. Senhor, perdoa-me.

31 de março. Despertei às 6 horas, acordei todos mas, por preguiça, não me levantei e dormi até as 9. Bebi chá, li; veio Aleksieiev e atrapalhou meu trabalho até o almoço. Depois da caçada bati papo com Balta até o jantar. Ele me contou uma dramática e interessante história da família Djemi.Eis o tema para o conto do Cáucaso ${ }^{119}$.

1 de abril. De novo acordei às 8 horas mas dormi até as 10. Li o "Sovremiênnik"; nele tudo é mau. Interessante que os livros ruins mostram-me mais as minhas carências do que os livros bons. Os bons obrigam-me a perder a esperança, Escrevi o capítulo sobre a oração, saiu molemente [...] Escrevi, escrevi e afinal comecei a notar que o raciocínio sobre a oração pretende a lógica e profundeza dos pensamentos; mas não conseqüentemente. Decidi terminar, sem sair do lugar, e agora queimei a metade - não a colocarei na novela, mas a conservarei como monumento $^{120}[\ldots]$.

7 de abril. 11 horas da noite. Apesar de ter acordado depois das 6, não pude vencer a preguiça e levantei-me só às 9 . Reli e fiz as correções definitivas no primeiro dia ${ }^{121}$. Estou

\footnotetext{
119 Tolstói não escreveu um conto com este tema. No rascunho da redação do conto "A incursão" menciona-se o montanhês Djemi quem é capaz, ao perder a cabeça, de atirar-se sobre as baionetas dos russos"

${ }^{120}$ Além do capítulo "Grisha" (Infầncia), onde descreve a oração noturna do peregrino Grisha, Tolstói escreveu uma reflexão à parte sobre a oração que não entrou na novela Infầncia.

121 "O primeiro dia" na novela Infầncia: a estada de Nikólenka na aldeia.
} 
absolutamente convencido de que ele não presta para nada. O estilo é demasiado negligente e há demasiado poucas ideias que possam desculpar o vazio do conteúdo. Porém, resolvi concluir as correções de toda a primeira parte e amanhã começarei o segundo dia. Será que vou enviar esta obra ou não? Eu não decidi. A opinião de Nikólenka resolverá este assunto. Eu me preocupo muito com isso e sinto um peso na alma e angústia. Gostaria muito de começar a novelinha caucasiana $^{122}$. Mas não me permitirei fazer isso - sem terminar o trabalho começado.

Almocei em casa. Li um excelente artigo de Buffon sobre os animais domésticos ${ }^{123}$. Sua extraordinária minúcia e plenitude na exposição não é, em absoluto, pesada. Às 6 fui cavalgar e zanguei-me estupidamente com o cachorro. Li Casa antiga sobre as viagens à ilha Aleutski $^{124}$. Bastante interessante apesar de mal escrito.

8 de abril. Levantei-me depois das 6 e estive lendo Casa velha. O dia foi estava tão bom que fui ao campo e cavalguei até às 12 horas. Almocei, comecei a escrever, mas não estava de ânimo; por isso, escrevi duas páginas e larguei o trabalho. Li até a noite. Preocupeime muito pelo meu irmão; por fim ele chegou numa companhia repulsiva que, depois de unirse a Iapichka, me encheu a paciência para lá da meia-noite. Foram embora. Eu estou jantando e vou me deitar. Pela manha recebi um bilhete grosso e tolo sobre o treinamento. Ele resolveu mostrar-me definitivamente, que ele pode me encher a paciência. Pela manhã traduzi um capítulo de Sterne. Vou me encontrar amanhã com Aleksiéev e vamos combinar tudo sobre os treinamento. Quero tanto ir para o mar, mas não tem como e não terminei o trabalho começado.

9 de abril. Levantei-me depois das 6. Veio Kneznedieliev e estive trabalhando até as 9 horas. Das 9 e até o almoço, não fiz nada. Me jogava de um lado para o outro, fui para onde meu irmão que tinha recebido uma bronca por causa da ausência. Resolvi inventar que estava doente e não ir ver Aleksiéev. Estou muito contente disso; apesar de que não devia porque isso é para mim um pretexto para a preguiça. Depois do almoço, de novo não fiz absolutamente nada. Nem sequer li. Tentei ler Hume, mas é demasiado enfadonho. Fui de

\footnotetext{
${ }^{122}$ Primeiras referências à ideia do conto "A incursão".

${ }_{123}^{123}$ Artigo "Algumas palavras sobre Buffon" ("Biblioteca para leitura", 1852, $\mathrm{N}^{\circ} 1$ 1).

${ }^{124}$ Trata-se das últimas partes do romance histórico Casa antiga de V. R. Zotov, intituladas "Monomaníaco" e “Os russos nas ilhas Aleutski” (Otiétchestvennye Zápiski, 1851, No 4 e 5).
} 
caça, encontrei Toptcheienko e rejeitei o serviço. Aleksiéev me estraga a vida. No campo me lembrei meu aborrecimento por causa das minhas tolas brigas com Guelke e Nóvikov. Estive em casa de Nikólenka, chegaram Sulimóvski, Ladyjenski e Ianóvitch. Saí de casa, li Hume enfadonho, mas não há nada para ler. Passei junto a casa de Pokunka e apesar da minha vontade, não entrei. Faltam 15 para as 10 . Sentei para jantar e agora vou dormir.

10 de abril. Levantei-me depois das 7 horas. Tive preguiça, estudei. Depois, comecei com o romance, mas, depois de escrever duas páginas parei porque me veio a ideia de que o segundo dia não pode ser bom sem interesse e que todo o romance parece um drama. Não me lamento, amanhã jogarei fora tudo o supérfluo. Almocei em casa e depois adormeci. Acordei e fui para o serviço. Em casa bati papo com Nikólenka e li. Fui para a casa de Sulimóvski, sem nenhum motivo. Aleksiéev parece tão tolo, a julgar pelos comentários. Tentarei demonstrar-lhe isso no primeiro encontro. Vou dormir às 11:30.

11 de abril. Levantei-me depois das 7. Li uma novela boba da "Biblioteca de leitrura". Almocei em casa, de novo li, fui para a casa de Nikólenka, estive no serviço, e não pude conter o riso ao ver a figura arrogante de Aleksiéev. Chegou em casa Nikólenka e eu ainda li um pouco. Fui bater na porta de Kasatka e, para a minha felicidade, um transeunte me atrapalhou. Estou doente. Hemorróide e dilatação das veias, deve ser por causa da abstinência. Pensei em mudanças que é necessário fazer na novela. Se a nostalgia e apatia que sinto agora passarem, amanhã começarei o trabalho. 10 horas. Janto e vou me deitar.

12 de abril. Levantei-me depois das 8 e chegou Nikólenka. Traduzi, depois escrevi, almocei, escrevi mais um pouco fui de caça, fui aos banhos, li, e vou dormir depois das 10 . Parece-me que Nikólenka como que está com pena de mim e está arrependido de ter me recomendado no serviço. Não sei se é bom ou ruim que entre nós não sejamos diretos. Estou agora com o mau costume de importunar todo mundo com a leitura da minha novela. Nikólenka foi embora de caça. Hoje me sinto melhor, mas moralmente débil e intensamente luxurioso. Amanhã, sem falta, escrever cartas a Tatiana Alexándrovna, Zagóskina, e Beer. Vou dormir às 10:30.

14 de abril. [Kizliar]. Acordei às 7 horas, fui caçar, não matei nada, às 12 horas cheguei a Kizliar [...] Li Sterne ${ }^{125}$. É admirável [...]. Li "Histoire d'Angleterre" ${ }^{126}$, não sem

\footnotetext{
${ }^{125}$ O romance Viagem sentimental por França e Itália.

${ }^{126}$ História da Inglaterra de David Hume. Tolstói a leu em uma tradução para o francês.
} 
prazer. Começo a amar a história e a entender a sua utilidade. Isso aos 24 anos; eis o que significa a má educação! Temo que isto será por pouco tempo. Vou me deitar, 9 horas.

16 de abril. Levantei-me às 9 horas. Li O judeu errante ${ }^{127}$, "Ermak" $" 128$ e uma lenda sobre Pedro o Grande ${ }^{129}$. Há um certo deleite particular em ler livros tolos, mas é um deleite apático.

17 de abril. Levantei-me tarde: li até o almoço e, depois do almoço, até as 2 horas diferentes tolices. Escrevi o novo capítulo “Os Ivin" ${ }^{130}$; mas ficou mal [...]

22 de abril. Cais de Chandrakóvskaia ${ }^{131}$. Levantei-me muito cedo e, se bem não cacei nada, pelo menos me deleitei com o encanto da manhã. Alguns cachorros saltam, outros não. Por isso, não sei por qual decidir-me. Em Bolshaia Orechevka falei com um mujique. Eles estão satisfeitos com sua existência, mas insatisfeitos com o domínio dos armênios ${ }^{132}$. Depois do almoço e do descanso fui atirar e estive pensando na escravidão. Pensarei direitinho na liberdade - será que vai ser publicado um folheto com minhas ideias sobre este assunto ${ }^{133}$ ?

24 de abril. [Kizliar] Levantei-me cedo, sentia-me muito fraco e fui até Kizliar. Perdi Ulatchin pelo caminho, e convenci-me de que os cachorros não galopam e em Serebriakovka escutei de um camponês uma história patética e artificial por causa da qual, contudo, me vieram as lágrimas aos olhos. Era acerca de como ele, depois de 40 anos queria encontrar-se com os parentes na Rússia. "Não sinto. Simplesmente, sou como uma árvore, só o coração bate como uma pomba. Ela ergueu os braços e caiu - "Mãezinha querida, levanta-te e acorda, veio voando a ti teu cucozinho da fronteira. E ali mesmo desmaiei» Cheguei a Kizliar às 11 horas, sem incidentes. Estava aborrecido, moralmente abalado, de saúde igual, se não melhor. Amanhã irei para a casa.

\footnotetext{
${ }^{127}$ Romance de Eugène Sue.

${ }^{128}$ Talvez se trate do artigo "Ermak ou Pequeno esboço da conquista da Sibéria" (Revista para a leitura dos alunos dos estabelecimentos de ensino militar,

${ }^{129}$ Livrinho de lubok (espécie de literatura de cordel) "Lenda acerca de como um soldado salvou Pedro o Grande da morte". 1849.

130 “Os Ivin”, capítulo 20 da terceira redação de Infầncia.

${ }^{131}$ Localidade no mar Cáspio.

132 Isto é, com a supremacia econômica dos armênios ricos localizados nessa região.

133 Algumas ideias avulsas sobre este tema aparecem nos manuscritos dos rascunhos do Romance de um proprietário russo.
} 
10 de maio. [Staragladkóvskaia] [...] Amanhã começarei a continuação de Infância e, pode ser, um novo romance ${ }^{134}$. Vou me deitar, 2 horas. A partir do dia de amanhã vou levantar-me cedo.

11 de maio. Levantei-me cedo, mas não posso desacostumar-me ao hábito de ler. Escrevi um pouco, sem qualquer amor-próprio e muito facilmente. Me veio o pensamento de que tenho sido muito parecido na minha orientação literária deste ano, com as pessoas famosas (em particular, com a senhoritas) que querem ver em tudo não sei que fineza particular e complicação. Dormi muito depois do almoço, li e zanguei-me com Vániuchka por causa da caleça.

18 de maio. [Piatigorsk ${ }^{135}$ ] Levantei-me cedo, estive escrevendo Infância; Ela me desgosta em excesso, mas vou continuar [...] Escrevi "Carta desde o Cáucaso"136, parece-me que com dignidade, mas não muito bem. Vou continuar: 1) as atividades, 2) o hábito de trabalhar, 3) o aperfeiçoamento do estilo. Vou me deitar. São 11 horas.

22 de maio. Levantei-me às 15 para as 5 (4:15), bebi água, tomei banho, doeu-me a cabeça e debilitei-me muito. Não escrevi nada e tagarelei com Buiémski sobre matemática e contei a ele o Banquete de Platão ${ }^{137}$, que ele tinha esquecido. Eu desejaria muito repetir matemáticas, só não sei se eu sou capaz disso agora. Buiémski começou a discutir menos e escutar. Almocei, dormi, bebi água, copiei a carta para a segunda parte que convém pensar. Estive relendo o capítulo "pesar" ${ }^{138}$ e comecei a chorar sinceramente. Realmente há passagens excelentes; mas há ruins. Eu tenho me tornado extraordinariamente descuidado em tudo. É preciso constranger-me. Vou me deitar, são 11 horas.

23 de maio. O mesmo estilo de vida, sinto-me e comporto-me bastante bem. Com Buiémski me dou bem. Lá estava Piatki a quem eu, não se sabe por que, alegrei muito. Acabei a carta bastante bem; escrevi a Andrei sobre o livro e o projeto ${ }^{139}$. Infância não me parece de todo ruim. Se a paciência desse para reescrevê-la por quarta vez, sairia ainda melhor. Vou me deitar, são 15 para as 12 .

\footnotetext{
${ }^{134}$ Primeira menção ao Romance de um proprietário russo.

135 Tolstói esteve em tratamento em Piatigorsk em 16 de maio de 1852.

${ }^{136}$ Nome original do conto "A incursão".

${ }^{137}$ Diálogo de Platão $O$ banquete. Tolstói o leu em uma tradução para o francês.

138 “O pesar”, capítulo XXVII de Infância.

${ }^{139}$ Carta ao administrador de Iásnaia Poliana, A. I. Sobolev, com a proposta tocante à propriedade (o projeto) e com indicações sobre a ordem da gestão do livro de contas. A carta não foi conservada.
} 
26 de Maio. Levantei-me às 6. Estava chovendo. Tomei banho e depois bebi água. Estive no médico e estive na Galeria Aleksandróvski. Termino o último capítulo. Sinto-me bastante bem, mas começam a doer um pouco as pernas e os dentes. A galeria é muito divertida; são mentiras dos oficiais, janotismo dos elegantes e as relações que se fazem lá. Sinto-me bem moralmente. Amanhã terminarei Infância, escreverei cartas e começarei a revisão definitiva. Vou me deitar. São 11 horas.

Levantei-me às 4:30. 27 de maio. O estilo de vida habitual. Pela manhã terminei Infância ${ }^{140}$ e durante todo o dia não pude fazer nada. $\mathrm{O}$ começo, que estou relendo, é muito mau; mas, apesar disso, vou mandá-la copiar e a enviarei imediatamente. Sento-me para jantar, são 15 para as 11 e logo depois vou me deitar. Escrevi uma fria e descuidada carta a Nikólenka.

29 de maio. Levantei-me depois das 4 horas. O estilo de vida habitual, a saúde não anda bem, dói-me a garganta. Não escrevi nada. Encomendei o pianoforte. Sonhei a manhã inteira com a conquista do Cáucaso. Apesar de saber que andar sonhando é prejudicial para as atividades cotidianas, não consigo desacostumar-me. Prezamos o tempo só quando fica pouco. E, o mais importante, contamos mais com ele quanto há menos pela frente. São 10:20, sentome para jantar.

30 de maio. O estilo de vida habitual. Escrevi uma carta a Tatiana Aleksándrovna que não lhe enviei e da qual não estou satisfeito. Não estou fazendo nada e penso na proprietária. Será que tenho eu um talento comparável ao dos novos literatos russos? Decididamente, não tenho. Sento-me para jantar, são 10:30.

31 de maio. Levantei-me cedo, tomei água, tomei banho, bebi chá e, até o almoço, não fiz nada. Não dormi e escrevi sobre a coragem ${ }^{141}$. As ideias são boas. Mas, pela preguiça e o mau costume, o estilo não é elaborado. Bebi água, estive em uma disposição de espírito alegre. Esteve em casa o escrivão, entreguei e li a ele a primeira parte. Definitivamente, ela não

\footnotetext{
${ }^{140}$ A terceira redação da novela.

${ }^{141} \mathrm{O}$ escrito sobre a coragem entrou a formar parte do conto "A incursão".
} 
presta para nada. Amanhã vou refazer a segunda (parte) e, na medida em que for reescrevendo, vou modificá-la ${ }^{142}$.

2 de junho. Li à noite, estive pensando. Bebi água em casa, mas não fiz nada. Embora haja erros ortográficos em Infầncia, ela ainda é passável. Tudo o que eu penso dela é que há novelas piores. Contudo, eu ainda não estou convencido de não ter talento. Eu, parece-me, não tenho paciência, nem o costume da clareza, também não há nada grandioso nem no estilo, nem nos sentimentos, nem nas ideias. Por último, eu ainda tenho, porém, dúvidas. Vou me deitar. São 9:10.

3 de junho. Levantei-me cedo, bebi água em casa, levei o estilo de vida habitual. Comi demais da conta no almoço, não estou fazendo nada e, se faço, faço-o mal.

Noto em mim um signo de velhice. Sinto e lamento-me da minha ignorância e digo de coração uma frase que ouvia freqüentemente das pessoas idosas e que sempre me surpreendia: “Agora lamento não ter estudado, mas já é tarde!”. É triste saber que a minha mente é deseducada, inexata e fraca (embora flexível), que meus sentimentos não possuem constância e força, que a minha vontade é tão instável que, da mais mínima circunstância, todas as minhas boas intenções se destroem, e saber e sentir que o germe de todas estas qualidades está em mim, ou esteve e que só ele não bastou para o desenvolvimento. Quanto tempo me esforçarei em instruir-me? Mas, será que vou melhorar muito? Já é tempo de desesperar-se; mas eu ainda tenho esperanças e conto com o acaso e a providência. Espero que algo desperte em mim a energia suficiente e que não me atole para sempre com meus elevados e nobres sonhos de glória, proveito e amor no insignificante redemoinho de uma mesquinha vida sem objetivo. Vou me deitar. São as 9:10.

4 de junho. O estilo de vida habitual, estive escrevendo a carta desde o Cáucaso, pouco, mas bem. Sinto-me bem. Eu me sentia atraído primeiro à generalização, depois à mesquinharia, agora se não achei um meio-termo, pelo menos entendo a sua necessidade e desejo encontrá-lo. Estive lendo As horas da veneração, em tradução do alemão ${ }^{143}$

\footnotetext{
${ }^{142}$ Início do trabalho na quarta redação de Infância.

${ }^{143}$ As horas da veneração, obra em vários volumes do poeta, historiador e moralista suizo Johann Heinrik Daniel Zschokke. A tradução russa em sete volumes foi publicada em São Petersburgo de 1834 - 1845.

* De acordo com a edição de 2009, as linhas longas indicam a ausência de palavras no texto original (N. de T.).
} 
livro que teria lido sem atenção, com troça ou teria me entusiasmado, mas agora ele já fez efeito em mim. Confirmou minhas ideias acerca dos meios para emendar meus assuntos e a suspensão das disputas. E eu decidi firmemente ir para a Rússia à primeira oportunidade e coûte que coûte ${ }^{* *}$, vender uma parte da propriedade e pagar as dívidas e, no primeiro encontro, terminar, pacificamente, sem vaidade, com todas as hostilidades e, de agora em diante, com bondade, modéstia e uma opinião benevolente sobre as pessoas, esforçar-me em reprimir a vaidade. Talvez este seja o melhor meio de livrar-me da minha incapacidade de relacionar-me com as pessoas. Vou me deitar. São 9:40. O escrivão atrasou-se. Um é um bêbado, o outro não sabe escrever. É uma desgraça.

5 de junho. É sabido que, em toda a floresta, não se encontram duas folhas semelhantes uma à outra. Reconheceremos a dessemelhança dessas folhas, não ao medi-las, mas pelos traços imperceptíveis que nos saltam aos olhos. A dessemelhança entre as pessoas, como seres mais complexos, é ainda maior e também a reconheceremos por alguma capacidade de unir, em uma só imagem, todos seus traços tanto morais como físicos. Esta capacidade constitui a base do amor. Da reunião de defeitos constitui-se, às vezes, tão imperceptível mas encantador caráter que ele suscita o amor - também nas pessoas conhecidas.

7 de junho. Levantei-me às 5:30, tomei banho, bebi água, estive tranqüilo e saudável, reescrevi e corrigi até as 6 da tarde, bebi água e estive lendo o Sovremiênnik de abril, que é ruim em extremo ${ }^{144}$. Sinto-me orgulhoso, não sei do que. Porém, estou satisfeito de mim no aspecto moral.

11 de junho. Estou melhor. Levantei-me às 8, apesar da debilidade e do suor, estive escrevendo e corrigindo. Almocei, li a História de Hume sobre Carlos ${ }^{145}$. A melhor eleição da filosofia é a história. Vou me deitar. São 11 horas. Estou satisfeito de mim.

15 de junho. Apesar do vento, estive nos banhos. Estive escrevendo. Terminei a segunda parte, a reli e, de novo, estou muito insatisfeito; porém, vou continuar. Depois do

\footnotetext{
** Custe o que custar (em francês no original).

${ }^{144}$ Das grandes obras do Sovremiênnik Nº 4 , durante o ano 1852 foram publicadas as continuações dos romances de A.A. Panaev na província, e de A.F. Pisiemski O noivo rico, e também Lembranças sicilianas de A. de Musse. ${ }^{145}$ Capítulo sobre Carlos I da História da Inglaterra de David Hume.
} 
almoço não escrevi. Comprei um quepe, rakhat-lukum ${ }^{146}$. Tudo é desnecessário. Amanhã perguntarei e falarei com a proprietária acerca da minha alimentação. Vou me deitar. São 5 para as 11 .

16 de junho. Levantei-me cedo, estive nos banhos e, alguma coisa de observar as pessoas honestas me fez entristecer. Me veio à cabeça que eu era eles. Estúpida vaidade! Agora sou mais honesto que nunca antes [...].

20 de junho. Levantei-me às oito, bebi água, depois escrevi. Acrescentei a descrição da colheita ${ }^{147}$ - bastante bem. Vániuchka está mal. O médico esteve, eu não o encontrei, ele trouxe o Sovremiênnik no qual está a novela de M, Mikhailov $A$ rendeira, muito boa, especialmente pela pureza da língua russa - em uma palavra, raspukolka ${ }^{148}[\ldots]$.

29 de junho. Levantei-me às 9. O doutor esteve aqui. Ele (me) manda a Jeleznovodsk. Reescrevi o último capítulo. Almocei, escrevi, bebi água, tomei banho e fui para a casa muito fraco. Li Profession de foi du Vicaire Savoyard. ${ }^{149}$ Está cheia de contradições - fragmentos abstratos e beleza incomum. Tudo o que eu tirei dela é a convicção da imortalidade da alma. Se para a compreensão da imortalidade da alma é necessária a compreensão da lembrança da vida anterior, então nós não fomos imortais. Por um lado, a minha inteligência se nega a compreender a eternidade. Alguém disse que o indício da verdade é a clareza. Embora seja possível discutir isso, a clareza permanece como o melhor signo e é sempre necessário verificar seus juízos por meio dela.

A consciência é nosso melhor e mais seguro guia, mas onde estão os indícios que diferenciam esta voz das outras? ... A voz da vaidade também fala tão forte. Por exemplo Aquele homem cujo objetivo é a própria felicidade é mau. Aquele cujo objetivo é a opinião dos outros, é fraco. Aquele cujo objetivo é a felicidade dos outros, é virtuoso. Aquele cujo objetivo é Deus, é grande. Mas será que aquele cujo objetivo é Deus, encontra nisso a felicidade? Que estupidez! E como parecia que essas ideias eram excelentes.

\footnotetext{
${ }^{146}$ É uma espécie de doce feito com amêndoas, nozes, mel avelã e às vezes outros frutos secos. É disposto em forma circular. Tolstói compara o formato do quepe com o doce (N. de T.).

${ }^{147}$ Descrição da colheita no capítulo "a caça" (Infầncia).

${ }^{148}$ Novela de M. Mikhailov A rendeira. (Sovremiênnik, 1852, № 5). Raspukolka, flor que não desabrochou (N. de T.).

149 "A confissão de fé um vicário simples" - quarto livro do romance Emílio ou da educação de Jean Jacob Rousseau.
} 
Eu acredito no bem e o amo, mas o que ele me indica, não sei. Será que a ausência de proveito pessoal não é sinal do bem? Mas eu amo o bem, porque ele é agradável e, em consequência, é útil. Aquilo que é útil para mim é útil para alguma coisa e bom só porque é bom em conformidade comigo. Eis os indícios que diferenciam a voz da consciência das outras vozes. Será que esta delicada diferença - que é útil e boa (e o que fazer com o agradável!) é o indício da verdade - a clareza? Não. É melhor fazer o bem sem saber o que é e não pensar nele. Diz-se, involuntariamente, que a maior sabedoria é o conhecimento de que ela não existe.

É ruim para mim aquilo que é ruim para os outros. É bom para mim aquilo que é bom para os outros. Eis o que sempre fala a consciência. Desejo ou ação? A consciência me reprochava as ações feitas com boas intenções mas que têm más consequências. O objetivo da vida é o bem. Esse sentimento é característico na nossa alma. O meio para alcançar o bem na vida é o conhecimento do bem e o mal. Mas será suficiente para isso um objetivo da vida? E se a vida inteira se devota a isso, será que não vamos errar e fazer o mal involuntariamente? Seremos bons, então, quando todas as nossas forças estiverem constantemente dirigidas a esse objetivo. Pode-se fazer o bem sem se possuir o conhecimento absoluto do que sejam o bem e o mal. Mas qual objetivo é mais próximo: o estudo ou a ação? A ausência do mal será o bem? As inclinações e o destino apontam para um caminho que nós devemos eleger mas sempre devemos trabalhar pelo o objetivo do bem. Será possível que cada distração, cada deleite que não traz proveito aos outros seja o mal? A minha consciência não os censura. Pelo contrário, ela os aprova. Essa não é a voz da consciência. A consciência, mais cedo ou mais tarde reprocha cada minuto usado sem proveito (embora também tenha sido usado sem prejuízo). $A$ variedade do trabalho é o prazer, Vou me deitar, são 15 para as 11.

30 de junho. Levantei-me às 8 , tomei banho, bebi água em casa, estive pensando, almocei.

Todo bem, exceto o bem que consiste em satisfazer a consciência, isto é, o bem que se faz ao próximo, é convencional, inconstante e independente de mim. Todas essas três condições vinculam o bem ao bem ao próximo. A satisfação das próprias necessidades é o bem apenas na medida em que pode contribuir para o bem ao próximo? Ela é um meio. Em que consiste o bem ao próximo? Ele não é, em absoluto, como o bem pessoal. Ou é o bem aquilo que eu acho como tal por minhas noções e inclinações. Por isso, as inclinações e medida da razão não possuem influência sobre a dignidade do homem. O avarento é bom se ele dá dinheiro; o 
sábio é bom se ele ensina; o preguiçoso é bom se ele trabalha para os outros. Mas, nesta opinião há dúvidas porque ela é objetiva. Aliviar os sofrimentos das pessoas é um bem subjetivo. Mas onde está o limite entre os sofrimentos e o trabalho? O sofrimento físico é claro e está condicionado ao hábito. Gostaria de dizer que fazer o bem -dar aos outros a oportunidade de fazê-lo também, eliminar todos obstáculos para isso- é a privação da ignorância e da depravação. Mas, de novo, não há clareza.

Ontem fiquei com a pergunta de se o deleite sem proveito é mau. Agora eu o afirmo. O homem que entender o verdadeiro bem, não desejará outra coisa. Além disso, não perder nem um minuto do poder para o conhecimento de fazer o bem é a perfeição. Não buscar o proveito para o próximo e sacrificá-lo para si é o mal. Entre um e outro -em maior ou menor medida da ação- há um espaço enorme em que o criador colocou as pessoas e deu-lhes o poder de eleger. Vou me deitar. São 11 horas.

1 de Julho. Levantei-me tarde, o clima está ruim, fui ao correio, recebi dinheiro e uma carta na qual escreve sobre as letras de câmbio entregues a Kopylov ${ }^{150}$. Escreverei uma carta amanhã a Andrei e Seriójenka. Eu posso perder Iásnaia e, apesar de qualquer filosofia, isso será para mim um golpe terrível. Almocei, escrevi pouco e mal, não fiz nada bom. Amanhã terminarei Infância e decidirei seu destino. Vou me deitar. São 11 1⁄2.

2 de Julho. Levantei-me às 5. Fui passear, terminei Infância e estive corrigindo-a. Almocei, li Nouvelle Héloïse ${ }^{151}$ e escrevi um rascunho de carta para o redator ${ }^{152}$. A justiça é o limite extremo da virtude, à qual está obrigado cada um. Por cima dela estão os degraus para a perfeição e abaixo dela está o vício.

4 de julho. Vániuska acordou-me às 5 horas. Levantei-me, terminei de corrigir e escrevi cartas: para Fiodurkun (bem), para Kopylov (satisfatoriamente), para Tatiana Aleksándrovna (tudo bem), para Beercha (inteligentemente, mas com descuido). Escrevi a procuração e requerimento e enviei tudo para o correio cuidadosamente. Almocei e não fiz nada, bebi água; com prazer demasiado intenso. observei Kriukova e bisbilhotei. Fui

\footnotetext{
${ }^{150}$ Carta de A. I. Sobolev, administrador de Iásnaia Poliana, sobre os assuntos de dinheiro com o comerciante N. F. Kopylov.

151 Júlia ou a nova Heloísa, romance de Jean Jacob Rousseau.

${ }^{152}$ Carta ao redator do Sovremiênnik N. A. Nekrásov. Tolstói reescreveu esta carta no dia 3 de julho e a reenviou junto com o manuscrito de Infância.
} 
imprudente em beber uma garrafa de schi azedo e, como conseqüência disso, comecei a pular e agora suo.

Não me ocupo tanto assim do objetivo que achei na vida. Será possível que esta não seja uma verdadeira, sólida regra, mas uma daquelas ideias que, sob a influência do amorpróprio, a vaidade e o orgulho, tão logo crescem como desaparecem? Não, esta é verdadeiramente uma regra. Minha consciência me diz isso. Eu quero que, como consequência de uma destas especulações, toda a minha vida seja melhor e mais leve. Não, esta regra precisa ser confirmada pelas ações e então as ações justificarão a regra. É necessário trabalhar.

Escrever uma carta a Nikólenka e Diakov. Primeiro escrever $A$ carta desde o Cáucaso [...]

7 de julho. [Jeloznovodsk] Levantei-me às 6, doíam-me os dentes e senti uma grande debilidade; bebi água. O bosque é muito bom. Escrevi uma carta a Tatiana Aleksándrovna que não enviarei, e uma carta a Nikólenka. Devo apressar-me em terminar o mais rápido possível a sátira das minhas Cartas desde o Cáucaso, mas essa sátira não me é própria ${ }^{153}$. Bebi água, tomei banho, de novo se me congelaram os dentes e agora me doem. Deitar-me-ei às 11.

8 de julho. Levantei-me às 8 . Bebi água e tomei banho, estive escrevendo $A$ carta desde o Cáucaso, satisfatoriamente. Me doeram os dentes, estive lendo, com grande prazer, Confessions ${ }^{154}$. Chegaram Khilkóvski e Alifer. Primeiro, raciocinou sobre meus planos de artilharia, ele fez refutações sensatas: posição não horizontal das rodas ${ }^{155}$. Pensarei nisso. Buiémski interveio na conversação e eu o ofendi. Vou me deitar com uma horrível dor de dentes. São 11 horas.

10 de julho. Levantei-me tarde e na mesma má disposição de espírito [...] Duas ideias encantadoras e possíveis, mas demasiado boas para realizar-se. Viver os três: Nikólenka, Macha e eu. Valerian, com certeza, vai opor-se, mas estas três pessoas são tão boas que elas e ele o fariam bem. 2) Vender Iásnaia a Nikólenka e receber 600 rubros de prata por ano. Se ficar a servir aqui. Vou me deitar. São 11 horas.

\footnotetext{
153 Nos rascunhos originais de $A$ incursão foram representados satiricamente o General (Príncipe A. I. Bariatinski) e alguns oficiais aristocratas. Depois, Tolstói enfraqueceu o caráter satírico dessas personagens.

${ }^{154}$ As confissões de Jean Jacob Rousseau.

${ }^{155}$ Trata-se da construção da nova caixa de carga para artilharia que Tolstói tentava criar.
} 
15 de julho. Levantei-me às 6. Disse desaforos a Buiémski. O estilo de vida habitual saudável também o estado d'alma. A carta desde o Cáucaso está na mesa e eu não me dedico a ela. Leio Rousseau e sinto, no tocante à educação e ao talento, que ele está acima de mim e no respeito a si próprio, firmeza e razão abaixo.

18 de julho. Ontem não pude dormir por muito tempo por causa do reumatismo e da luz da lua; sentei-me junto à janela e estive pensando muito bem. Levantei-me tarde. Bebi água, tomei banho, fiz um conhecido, estive passeando, conversei e não fiz absolutamente nada. Estou meditando o plano do romance do proprietário russo com um objetivo ${ }^{156}$.

Eu oro assim: Deus, livra-me do mal, isto é, livra-me da tentação de fazer o mal e concede-me o bem, isto é, a possibilidade de fazer o bem. Experimentarei eu o mal ou o bem? -Sim, será a tua vontade!- Será possível que eu nunca tirarei uma ideia de Deus tão clara assim como a ideia da virtude? Esse é agora meu desejo mais forte.

$\mathrm{O}$ castigo é a injustiça. $\mathrm{O}$ castigo não pode determinar o homem, ele é demasiado orgânico, ele mesmo é o homem. O castigo, como a ameaça, é injusto porque o homem sacrifica um mal certo por um bem duvidoso. $\mathrm{O}$ isolamento -incluso a morte- são justos. A morte não é o mal já que é uma lei indubitável de Deus. A noção de Deus resulta da consciência da fraqueza do homem.

Vou me deitar. São 9 1/2. Parece-me que todo o tempo passado por mim em Jeleznovodsk na minha cabeça se transforma e prepara muita coisa proveitosa. Não sei o que sairá disso.

20 de julho. Não dormi à noite, levantei-me às 6 , bebi água em casa, estive na casa de Roger. Passei pelo No 8. A saúde parece melhor; mas, não faço nada. Não fumo desde hoje. Amanhã começo a refazer Carta desde o Cáucaso e me substituirei por um voluntário. Vou me deitar. São 9 1/2.

3 de agosto [Piatigorsk] Levantei-me cedo [...] Khilkóvski foi embora. A minha disposição de espírito é maravilhosa. Passei o dia inteiro no jardim. Li Político ${ }^{157}$. No meu romance eu exponho o mal do governo russo e, se o achar satisfatório, dedicarei o resto da

\footnotetext{
${ }^{156}$ Trata-se do Romance de um proprietário russo. Seu "objetivo" consistia em mostrar "a impossibilidade da vida para um proprietário instruído do nosso tempo com a escravatura".

157 Político, diálogo de Platão.
} 
vida à elaboração de um plano eleitoral aristocrático, ligado ao governo monárquico, baseado nas eleições existentes. Eis o objetivo para uma vida virtuosa. Agradeço-te a ti, Senhor; Dáme forças.

6 de agosto. [Galiugai ${ }^{158}$ ] Caminho: os sonhos, pequenos enfados, desordem. Penso e repenso na campanha e em tudo aquilo que não resolvi. Penso com meu irmão e vou ficar sabendo de tudo direitinho. O futuro exige de nós mais do que a realidade. Essa inclinação é boa, se pensamos no futuro desse mundo. Viver no presente, isto é, alcançar o melhor modo de vida no presente - Eis a sabedoria. Em Galiugai. Travar conhecimento com o capitão do exército e ir ver $\mathrm{K}$.

17 de agosto. [Starogladkóvskaia] Estive na revista das tropas. O melhor que posso esperar do serviço é ser demitido. Depois de ir à revista, dormi até as 9 horas. A cabeça está muito leve. As causas da decadência da literatura: a leitura de obras simples se tornou um hábito e escrever a obra se tornou uma profissão. Escrever um livro bom na vida é mais que suficiente. E ler um também.

A disciplina é necessária só para os conquistadores. Para cada homem existe um caminho particular pelo qual cada situação torna-se para ele autêntica. Nada tem me persuadido da existência de Deus e de nossas relações com ele como a ideia de que são dadas faculdades a todos as criaturas conforme as necessidades que eles devem satisfazer. Nem mais, nem menos.

Para que, então, é dada ao homem a faculdade de compreender a causa da eternidade, a infinitude, a onipotência? Esta tese da existência de Deus é uma hipótese confirmada por meio de indícios. A fé, conforme o grau de desenvolvimento do homem, aumenta a sua veracidade.

18 de agosto. Eis quatro regras que norteiam as pessoas: 1) Viver para a própria felicidade. 2) Viver para a própria felicidade, fazendo o menor mal possível aos outros. 3) Fazer pelos outros aquilo que eu gostaria que fizessem por mim. 4) Viver para a felicidade dos outros. Estive o dia inteiro no serviço ou com meu irmão e com os oficiais. O plano do romance começa a vislumbrar-se.

\footnotetext{
${ }^{158}$ Stanitsa na margem direita do Terek.
} 
25 [de agosto] Matei uma galinhola. Estive duas vezes no treinamento militar. Não se deve exigir a possibilidade de inocência absoluta a si próprio. Quão freqüentemente todo o gênero humano se afasta da justiça. É necessário trabalhar desde uma perspectiva intelectual. Sei que seria mais feliz se não soubesse desse trabalho. Mas Deus me colocou nesse caminho: devo ir por ele.

28 de agosto de 1852. Tenho 24 anos; e eu ainda não fiz nada. Sinto, não sem motivo já há oito anos, que luto com as dúvidas e as paixões. A que estou destinado? O futuro o descobrirá. Matei três galinholas.

29 [de agosto] Fui com Nikólenka à caça. Matei um faisão e uma lebre. Dormi, recebi uma carta de Petersburgo de Islávin (carta mesquinha à qual responderei, em lugar de mordaz, como eu gostaria de fazer, com verdadeiro desprezo - com o silêncio ${ }^{159}$ ) e do redator que me alegrou até a estupidez ${ }^{160}$. Sobre o dinheiro, nem uma palavra. Amanhã, escrever cartas: a Nekrásov e Buiémski e escrever.

2 de setembro. Exercício eqüestre. À tarde matei três faisões. Que encanto que é David Copperfield ${ }^{161}$.

3 de setembro. Vi a meia lua do lado esquerdo ${ }^{162}$. A inclinação da alma é: o amor ao próximo. A inclinação da carne é: o bem pessoal. Por uma causa misteriosa, o corpo e alma encerram um enigma que contradiz as inclinações. Eu, talvez, não dormi o suficiente e, ao ir para o treinamento, estava mal-humorado. Utilizarei todo o tempo que for necessário, ficarei aqui para estar melhor e preparar-me para essa vida que escolhi.

5 de setembro. $\mathrm{O}$ dia inteiro estive em casa. Me dói a garganta. Escrevi uma carta a Nekrásov. Estou com preguiça de escrever, mas com vontade.

\footnotetext{
${ }^{159}$ Carta zombeteira de V. A. Eslavin, de 12 de Agosto, em resposta ao pedido de Tolstói de que enviasse o programa para o exame de oficial.

${ }^{160}$ Carta de N. A. Nekrásov, de meados de agosto de 1852, com o parecer de aprovação referente a Infância. “A orientação do autor, a singeleza e realismo do conteúdo constituem o mérito inalienável desta obra.

161 David Copperfield, romance de Charles Dickens. A tradução para o russo foi publicada no Sovremiênnik, $1851, \mathrm{~N}^{\mathrm{o}} 1-9$.

${ }^{162}$ De acordo com a tradição popular, era coisa de azar ver a lua do lado esquerdo. Indicava falta de dinheiro e outras coisas desse tipo. Referências como essa encontram-se também em Púchkin.
} 
19 de setembro. Estive caçando. O plano do meu romance parece suficientemente maduro. Se eu não passo a cuidar dele agora, é porque sou um preguiçoso incorrigível.

22 de setembro. Deixaram de doer-me os dentes e eu haveria sentado para escrever mas chegou Tsezarkhan e me atrapalhou. Fui de caça com Sulimóvski, matei três faisões. Estive lendo a História da guerra do ano $13^{163}$. Só um preguiçoso ou um homem incapaz de qualquer coisa pode dizer que não achou ocupação. Redigir a autêntica e verdadeira história da Europa deste século. Eis um objetivo para toda a vida. Há poucas épocas na história, tão instrutivas como esta e tão pouco estudadas - estudadas de forma imparcial e com exatidão tal como nós debatemos agora a história do Egito e Roma. A riqueza, a frescura das fontes e a imparcialidade histórica nunca vistas são a perfeição. Antes de começar a pensar e escrever, me veio ainda à cabeça uma condição da beleza na qual não havia pensado - a nitidez dos caracteres.

29 de setembro. Li o novo Sovremiênnik. Uma boa novela parecida com a minha Infância, mas superficial ${ }^{164}$.

30 de setembro. Sinto-me doente, as pernas e os pômulos me doem. Escrevi um pouco, fui de caça. Recebi uma carta de Nekrásov - elogios mas não dinheiro ${ }^{165}$.

1 de outubro. Abandonei Chkalik ${ }^{166}$, muito bem. Se cada dia eu escrever uma quantidade assim então, em um ano escreverei um bom romance. É enfadonho sem Nikólenka, embora tenha me organizado.

2 de Outubro. Levantei-me cedo, estive lendo em casa, chegou Nikólenka. Fui a casa dele até o almoço. Depois do almoço dormi, dei uma caminhada, escrevi uma carta a Tatiana Aleksándrovna, estive admirando Iapichka, safaguildy ${ }^{167}$, as danças cossacas de roda com canções e disparos, chacais e a radiante noite estrelada - é glorioso. Uma personagem particular. Escrevi bem meia folha. Às vezes me sinto incômodo com Nikólenka. O melhor meio é não envergonhar-se. Se não é agradável estar com ele, então, não estar com ele.

\footnotetext{
${ }^{163}$ Descrições da guerra de 1813 de A. I. Mikhailovski-Danilievski em dois volumes. 1860.

${ }^{164}$ Novela de P. A. Kulich História de Uliana Terentievna (Sovremiênnik, 1852, No 8) assinado como Nikolai M.

${ }^{165}$ Carta de 5 de setembro de 1852 (Nekrásov, T. 10, No 147).

166 Isto é, sem terminar de escrever o segundo capítulo do Romance de um proprietário russo no qual é representado o kulak e velhaco Chkalik.

${ }^{167}$ Mais exatamente safagueldin - cumprimento tártaro que significa "bem-vindo".
} 
4 de outubro. Resolvi a questão do desfecho do romance: Depois do inventário da propriedade e do trabalho fracassado na stalitsa, das paixões mundanas, do desejo de encontrar uma amiga e da decepção com as escolhas, a irmã de Sukhonin o deixa. Ele compreende que sua paixão não é vil (má) mas prejudicial e que é possível fazer o bem e ser feliz suportando o mal ${ }^{168}$.

Matei quatro faisões, estive nos banhos. Estive na casa de Aleksiéev quem me dispensou do plantão.

5 de Outubro. Parece-me que eu, aqui, no Cáucaso, não estou em condições de descrever a vida camponesa. Isso me perturba.

8 de outubro. Estive o dia todo, até a noite em um estranho estado de apatia insuperável: nem ler, nem escrever. Li não sei que porcaria, depois escrevi 1 1/2 folha. É preciso afastar para sempre a ideia de escrever sem correções. Três, quatro vezes, são ainda pouco. Ontem mandei Vániuchka ao quartel por causa de sua grosseria. Eu, mais do que nunca, estou decidido a demitir-me, mesmo sem haver condições. O serviço atrapalha duas vocações das quais somente eu sou consciente, especialmente a melhor, a mais nobre e importante e aquela em que tenho mais certeza de achar sossego e felicidade. Tudo se resolverá dependendo de se Brimmer me propôs ou não. Se ele me propôs, então esperarei para escrever em Petersburgo, senão, pedirei a demissão imediatamente ${ }^{169}$.

13 de outubro. O correio me atormenta com a espera. Saí com Nikólenka e sozinho, matei dois faisões, escrevi muito [...] quero escrever uns esboços caucasianos para a formação do estilo e por dinheiro ${ }^{170}$.

19 de outubro. A simplicidade é a condição mais importante da beleza moral. Para que os leitores simpatizem com o herói, para que eles reconheçam nele tanto as próprias fraquezas como as suas virtudes; as virtudes são possíveis, as fraquezas são necessárias. Me veio a ideia de estudar música. Com aqueles ou com outros mas espero, no dia de amanhã começar a

\footnotetext{
${ }_{168}$ Anotação relativa ao Romance de um proprietário russo. Sukhonin é uma personagem do romance.

${ }^{169}$ Considerando suas duas vocações - a criação literária e melhorar a vida dos servos - Tolstói estava à espera de um grau de oficial para o qual tinha sido indicado pelo superior de artilharia da Divisão do corpo do Cáucaso E. V. Brimmer

${ }^{170}$ Esta ideia não foi realizada. Nos papéis de Tolstói conservou-se apenas o rascunho do esboço "Viagem ao Mamakai-Yurt" (Obras Completas Reunidas, tomo 3).
} 
trabalhar infatigavelmente. A ideia do romance é feliz. Ele pode não ser a perfeição, mas ele sempre será um livro útil e bom. Por isso deve-se trabalhar e trabalhar nele sem parar.

Se a carta do redator me exortar a escrever esboços do Cáucaso, então eis o programa deles: 1) Os costumes do povo: a) História de $\mathrm{Sal}^{171}$, b) O conto de Balta ${ }^{172}$, c) A viagem ao Mamakai-Yurt. 2) A viagem ao mar: a) A história do alemão b) $\mathrm{O}$ governo armênio, c) A peregrinação dos chefes da família ${ }^{173}$. 3) A guerra: a) A passagem (a transição), b) $O$ movimento, c) $\mathrm{O}$ que é valentia? ${ }^{174}$

Bases do romance de um proprietário russo: O herói busca a realização de um ideal de felicidade e justiça na vida aldeã. Ao não encontrá-lo nela, decepcionado, procura-o na família. Seu amigo, ela ${ }^{175}$, leva-o à ideia de que a felicidade está não no ideal, mas [no] trabalho vital constante, tendo um objetivo: a felicidade dos outros [...].

21 de outubro. Escrevi pouco ( $3 / 4$ de folha). Em geral, estive o dia inteiro de mal humor; depois do almoço, Iapichka me atrapalhou. Mas os relatos dele são admiráveis. Esboços do Cáucaso: 4) Os relatos de Iapichka: a) sobre a caça, b) sobre a vida antiga dos cossacos, c) sobre suas aventuras nas montanhas ${ }^{176}$.

28 de outubro. A partir do dia de hoje devo considerar, de novo, o tempo da minha expulsão. Devolveram meus papéis. Assim sendo, antes de meados, isto é, do mês de julho de 1854 não posso esperar ir para a Rússia, nem demitir-me antes de 1855 . Vou ter 27 anos. Ah, é muito! Ainda três anos de serviço. Devo usá-los proveitosamente. Acostumar-me ao trabalho. Escrever alguma coisa boa e preparar-me, isto é, elaborar as regras para a vida na aldeia. Deus, ajuda-me. Escrevi muito pouco, fui de caça e conversei em casa de Nikólenka. Ele é egoísta.

29 de Outubro. A última palavra está confirmada agora. Além disso, eu sou o mais tolo que aceitou de coração sua advertência de que tinha pouco dinheiro. Escrevi uma carta a

\footnotetext{
${ }^{171}$ Provavelmente, a história de Solomanida, cossaco da stanitsa Starogladkóvskaia. O esboço não foi escrito.

172 Provavelmente, a "História da família Djemi” contada a Tolstói por Balta (anotação de 31 de março de 1852). O tema do esboço foi parcialmente realizado no conto $A$ incursão.

${ }^{173}$ Estes temas ocorreram a Tolstói na época da sua viagem ao Mar Cáspio, em Abril de 1852. Os esboços não foram escritos.

${ }^{174}$ Os projetos não se realizaram. Esses temas foram parcialmente utilizados nos contos A incursão e A derrubada do bosque.

${ }^{175}$ Tolstói fala de amigo no sentido do amor cortés. "Ela" é o "amigo" que guia o herói (N. de T.).

${ }^{176}$ Tais esboços não foram escritos. Os relatos de Iepichka apareceram na novela Os cossacos.
} 
Tatiana Aleksándrovna; uma carta triste... Saí com os cachorros... Nikólenka veio e leu para mim suas anotações sobre a caça ${ }^{177}$. Ele tem muito talento. Mas a forma não é boa. Que ele abandone os relatos sobre a caça e dê mais atenção às descrições da natureza e os costumes. Elas são variadas e muito boas nele. Não escrevi nada, não li.

31 de Outubro. Ontem e hoje escrevi um pouco. Me dói um dente. Li minha novela, mutilada até o extremo ${ }^{178}$.

8 de Novembro. Abri o caderno, mas não escrevi nada. Escrevi uma carta dirigida ao redator, a qual me tranquilizou, mas que não enviarei ${ }^{179}$. Fui de caça, aos banhos, em casa de meu irmão e parece-me que apanhei um resfriado.

13 de novembro. Bebi um copo e fui embora com os cachorros, estive rodando até a noite, ainda tomei uns tchikhires ${ }^{180}$, fui até a casa de Khilkóvski, devolvi o dinheiro e fiquei duas horas. Nikólenka aflige-me muito. Ele não gosta de mim e não me entende. $\mathrm{O}$ mais estranho de tudo nele é que uma grande inteligência e um coração bom não realizaram nada. Falta não sei que relação entre estas duas qualidades. Iapichka disse muito bem que eu sou alguma coisa odiosa. E eu sinto exatamente isso: que não posso ser agradável para ninguém e que todos são uma carga para mim. Eu, sem querer, ao falar de qualquer coisa, digo com os olhos coisas que não são agradáveis de ouvir para ninguém e eu mesmo sinto vergonha de dizê-las

17 de novembro. O dia inteiro estive em casa, escrevi um pouco. Tudo o escrito está esboçado de forma tão demasiadamente negligente que é força refazê-lo. Amanhã irei a Chelkovaia $^{181}$. Mais uma vez escrevi uma carta a Diakov e ao redator as quais, de novo, não enviarei ${ }^{182}$. A carta para o diretor é demasiado ríspida e Diakov não me compreenderá. Devo acostumar-me a que ninguém nunca me entenderá. Esse destino, talvez comum a todas as pessoas, é muito penoso.

\footnotetext{
${ }^{177}$ Esboço de Nikolai Nikoláevitch Tolstói A caça no Cáucaso. Foi publicada em 1857 no Sovremiênnik, № 2.

178 A novela Infầncia publicou-se assinada por "L. N." no Sovremiênnik No 9 de 1852 com emendas da redação feitas por exigência da censura.

${ }^{179}$ Carta a Nekrásov em que expressa a revolta por causa das mudanças de redação na novela Infância. O texto da carta é desconhecido.

${ }^{180}$ Vinho tinto caseiro típico do Cáucaso (N. do T.).

${ }^{181}$ Chelkovaia, isto é, Chelkozavodskaia e a abaixo mencionada Parobotche, isto é Parobotcheva, são stalitsas na margem esquerda do rio Terek.

${ }^{182}$ Carta de 18 de novembro de 1852 não remetida a N. A. Nekrásov (Tomo 17 da presente edição, № 11).
} 
[25 de novembro. Starogladkóvskaia] 20, 21, 22, 23, 24, 25 cacei muito mal em Parobotche e Chelkovaia, mas fui bom e não me aborreci. Falei um pouco com Nikólenka, revehei-lhe parcialmente uma parte do meu plano de vida e falei da metafísica de N. $\mathrm{S}^{183}$. A metafísica é a ciência sobre os pensamentos não sujeitos à expressão das palavras. Sveridov chegou hoje em casa e foi tolo. Ontem escrevi um pouco, satisfatoriamente. Li a crítica sobre a minha novela ${ }^{184}$ com alegria desacostumada e contei-o a Ogolin.

28 de Novembro. Tive um sono horrível com Tatiana Aleksándrovna. Fui com Iepichka $^{185}$, nada me ofendeu. Estive na casa do meu irmão, tentei escrever, não saiu. É evidente que para mim passou o tempo de verter o vazio no vazio. Escrever sem objetivos e esperanças na utilidade, decididamente, não posso.

29 de novembro. Fui procurar abetardas, estive nos banhos e na casa de Nikólenka. Recebi uma carta de Iásnaia e 100 rublos. Começarei o aperfeiçoamento da descrição da guerra $^{186}$ e Adolescência. O livro vai como deve $\operatorname{ser}^{187}$.

30 de novembro. Estive pensando muito mas não fiz nada. Amanhã pela manhã me dedicarei a refazer a descrição da guerra e, à noite, adolescência que, definitivamente, decidi continuar. Quatro épocas da vida constituem meu romance antes de Tíflis ${ }^{188}$. Posso escrever sobre ele porque ele está longe de mim. E como é o romance de um homem inteligente, sensível que se perdeu, ele será instrutivo, ainda que não dogmático. Já o romance do proprietário russo será dogmático [...].

1 de dezembro. Estive escrevendo o dia inteiro a descrição da guerra. Tudo o que é satírico não me agrada e como tudo está em sentido satírico, é necessário refazer tudo [...].

\footnotetext{
${ }^{183}$ Não foi possível decifrar a quem se referia Tolstói

${ }^{184}$ Artigo de S. S. Dudychkin aparecido no No 10 de Otiétchestvennye zápiski: "Há tempos não nos acontecia escreveu o crítico- lermos obras mais comoventes, mais nobremente escritas, mais impregnadas de simpatia por aqueles fenômenos da realidade, pela representação para as quais se devotou o autor... Se é esta a primeira obra do senhor L.N., então, não podemos não cumprimentar a literatura russa pela aparição do maravilhosos novo talento".

${ }^{185} \mathrm{Na}$ anotação do diário de 10 de agosto de 1851, Tolstói fala pela primeira vez de Iapichka (Epifan Sekhin, conforme as notas da edição soviética), mas apenas aqui Tolstói se refere a ele, por primeira vez, como Iepichka. As notas da edição soviética esclarecem que se trata da mesma pessoa (N. do T).

${ }^{186} \mathrm{O}$ conto $A$ incursão.

${ }^{187}$ Isto é, o Romance de um proprietário russo.

${ }^{188}$ Ver nota 39 do diário de 1851.
} 
3 de dezembro. Escrevi muito. Parece-me que vai ser bom. E sem sátira. Não sei que sentimento interior fala fortemente contra a sátira. Incluso me é desagradável descrever o lado ruim de toda uma classe de pessoas, não só de um indivíduo.

11 de dezembro. Estive na revista na casa de Levin. Estive cavalgando. Decididamente, sinto vergonha de ocupar-me com tolices como meus contos quando tenho começada uma coisa milagrosa como é o Romance do proprietário. Para que dinheiro, a estúpida fama literária. É melhor escrever com convicção e fervor uma coisa boa e útil. De um trabalho assim, nunca nos cansaremos. E quando terminar -se tiver vida e virtude- acharei uma ocupação.

24 de dezembro. É véspera do natal. Terminei o conto ${ }^{189}$. Não é mau.

26 de dezembro. Leio Lêrmontov por terceiro dia consecutivo. Estive em casa de Nikólenka. Vi Aleksiéev; nós começamos a fazer as pazes, mas eu estou confuso. Quando serei sempre e em todas as circunstâncias livre! Não escrevi nada, mas amanhã começarei, sem falta. Encontrei-me tarde com um cossaco abraçado com cossacas e lembrei-me, com prazer, das noitadas com as mulheres. Especialmente pela manhã, quando sais. Enviei o conto com Sulimóvski e contei-o a ele.

27 de dezembro. Dormi muito. Teria começado o romance. Os oficiais me atrapalharam. Estive cavalgando e, uma vez cheguei, li e estive escrevendo versos ${ }^{190}$. Está indo bastante bem. Penso que isto me será muito útil para a formação do estilo. Não posso não trabalhar. Graças a Deus; mas a literatura é uma ninharia e eu gostaria de escrever aqui um regulamento e um plano de administração.

\footnotetext{
${ }^{189}$ Conto $A$ incursão, publicado no Sovremiênnik No 3 de 1853 , assinado por "L. N".

${ }^{190}$ Provavelmente o poema "em direção à armadilha" (Obras Completas Reunidas, tomo 1).
} 
[1 de janeiro. Tchevlennaia?] Saí com a divisão ${ }^{191}$ : alegre e saudável.

6 [janeiro. Gróznaia]. Houve uma estúpida parada. Todos, especialmente meu irmão, bebem e isso me desagrada muito. A guerra é um assunto tão injusto e mau que aqueles que lutam esforçam-se em abafar em si a voz da consciência. Será que eu faço bem? Deus, instruime e perdoa-me se eu faço mal.

12 de janeiro [...]. Imaginei um esboço: "Baile e bordel"192. Dói-me a garganta mas estou de bom humor.

21 de janeiro. Escrevi um pouco mas tão descuidadamente, sem fundamento e tão pouco que não se parece com nada. As faculdades mentais se embotam a tal ponto por causa dessa falta de objetivo e confusão da vida e do comum das pessoas que não querem ou não podem entender nada sério ou nobre. Estou sem um tostão e essa situação me obriga a temer que não pensem mal de mim o que demonstra que eu poderia fazer algo mau. Não quero mais jogas às cartas. Não sei como me ajudara Deus. Que bendito proveito me faz o Cáucaso quando levo aqui semelhante vida? Ao chegar a Tula, eu, sem querer, entrarei de novo na senda dos Kulikovski, Gach e os Liutikov. Não, chega!

20 de fevereiro [Acampamento na serra Katckкalykovski] Saímos de Gróznaia para Kurinskoe, sem ação. Ficamos lá duas semanas, depois começamos o acampamento na serra Katchkalykovski. Houve, no dia 16, ações de artilharia à noite e no dia 17 durante o dia. Eu me comportei bem ${ }^{193}$. Durante este tempo todo tenho ganho, mas agora, estou sem um tostão embora me devam.

Não me conteve neste aspecto do caráter, porém, comportei-me, em geral, bem. Hoje Ogolin me disse que recebi a cruz. Queira Deus, é só para Tula.

\footnotetext{
${ }^{191}$ Tolstói participou da campanha contra os exércitos de Chamil, que se prolongou por dois meses e meio.

192 Primeira referência ao projeto do conto Noite de natal (tomo 1, Obras Reunidas, editora Khudojestwennaia Literatura, 1965, em que se baseia esta tradução).

${ }^{193}$ Por sua participação no combate do dia 17 de fevereiro, Tolstói foi proposto para promoção a alferes.
} 
10 de março [Acampamento junto ao rio Gudermes]. Não recebi a cruz ${ }^{194}$ e fiquei no piquete por benevolência (mercê, graça) de Olifer ${ }^{195}$. Em conseqüência, o serviço no Cáucaso não me trouxe nada exceto dificuldades, ociosidade e más relações... Devo acabar logo [...].

16 de abril [Starogladkóvskaia]. Há tempos que não escrevo. Depois de chegar a Starogladkóvskaia, perto de 1 de abril, continuei a viver do mesmo modo em que vivi na campanha. Como um jogador que teme contar o que está escrito nele. Perdi, de brincadeira, 100 rublos de prata para Sulimóvski. Fui, sem êxito, a Tchervlennaia para receber um certificado da doença. Gostaria de demitir-me, mas a falsa vergonha de voltar à Rússia sendo júnker, decididamente, me refreia. Esperarei a promoção que será pouco provável. Eu já estou acostumado a todos os fracassos possíveis. Em Novogladkóvskaia, se não pequei na Segundafeira Santa foi porque Deus me salvou. Gostaria de ascender à antiga senda da solidão, da ordem e dos nobres e bons pensamentos e ocupações. Agora experimento, por primeira vez, um sentimento extraordinariamente triste e penoso - o pesar da perda da juventude sem proveito nem deleite. Sinto que a juventude foi embora. É tempo de despedir-se dela.

18 de abril. Levantei-me cedo, li a obra de Avieev $O$ dragão voador ${ }^{196}$, não escrevi mal. O plano do conto apenas agora começa a manifestar-se com clareza. Parece-me que o conto pode ser bom se souber evitar habilmente seu lado tosco. Contudo, passei muito tempo ocioso pela falta de costume de trabalhar [...].

$8,9,10,11,12,13,14,15$ de maio. Nestes sete dias não fiz nada [...]. Recebi cartas de Nekrásov, Serioja e Macha: todas sobre a minha atividade literária, que elogiam meu amorpróprio $^{197}$. O conto "Noite de natal" está completamente estudado. Quero dedicar-me e entrar de novo na senda da vida honrada: leitura, escritura, ordem e abstenção. Por causa de moças que não possuo e de uma cruz que não receberei vivo aqui e mato os melhores anos da minha vida. Uma estupidez! Senhor, dá-me a felicidade.

\footnotetext{
${ }^{194}$ Tolstói ainda mereceu a Cruz de Jorge (Георгиевский крест) pela campanha invernal de 1852, mas não a recebeu devido a que seus documentos de dispensa do, assim chamado, serviço cidadão chegaram atrasados.

${ }^{195}$ Por ordem do capitão do Estado Maior Olifer, Tolstói foi confinado no calabouço (piquete) para que, durante a inspecção da bateria de brigada comandada por Levin, Tolstói não estivesse de guarda.

${ }_{197}^{196}$ Romance de A. V. Avdieev $O$ dragão de fogo.

${ }^{197}$ Carta de Nekrásov de 6 de abril de 1853, sobre as deturpações da censura no conto "A incursão". Carta de Serguéi Nikoláevitch Tolstói de 12 de Abril, com uma opinião positiva sobre "A incursão". A carta de Maria Nikoláievna Tolstói não se conhece.
} 
$15,16,17,18,19,20,21,22$ de maio [...]. Abandonei o conto ${ }^{198}$ e escrevo Adolescência com aquela mesma vontade com que escrevi Infância. Espero que seja tão boa assim. Todas as minhas dívidas estão pagas. Está aberto para mim um campo literário brilhante. Devo conseguir um grau. Sou jovem e inteligente. O que devo desejar? Devo trabalhar e conter-me e eu ainda poderei ser muito feliz.

22, 23, 24, 25, 26, 27 [de maio]. Absolutamente nada especial. Escrevi pouco, mas, definitivamente, pensei em Adolescência, Juventude, Mocidade, as quais espero acabar. Hoje Aleksiéev me enviou um papel por meio do qual Brimmer promete dispensar-me com o grau de civil $^{199}$. Quando me lembro do meu serviço, sem querer, fico fora de mim. Ainda não me resolvi, embora por hoje minha percepção da vida se mantenha por aquilo que me determinei em Piatigorsk, não me acontece cair em melancolia. Vou pensá-lo direitinho. Não consigo me acostumar em tudo à exatidão e ordem, embora me esforce.

23 de Junho. Não escrevi nada durante quase um mês. Nesse tempo, fui a Vozdvijenskaia com meus amigos. Joguei às cartas e perdi $\operatorname{Sultan}^{200}$. Por pouco e não caí prisioneiro, mas nessa ocasião me comportei bem, embora demasiado sentimental ${ }^{201}$. Ao chegar em casa, resolvi passar um mês aqui, para terminar Adolscência, mas tenho me comportado a semana inteira tão desordenadamente, que fiquei tão pesaroso e triste como acontece sempre que estou insatisfeito de mim. Ontem Grichka contou que eu estava pálido depois que os tchetchenos me prenderam e que eu não me atrevo a bater no cossaco que golpeou uma mulher, para que ele não me devolva o golpe. Tudo isso me transtornou tanto, que tive um sonho muito vivamente triste e, tendo acordado tarde, li como Obri suportou sua infelicidade e como Shakespeare diz que o homem se conhece na sua infelicidade ${ }^{202}$. De repente, tornou-se-me incompreensível como eu pude, durante todo esse tempo, comportar-

\footnotetext{
198 "Noite de natal".

${ }^{199} \mathrm{Na}$ época de Tolstói, existia na Rússia a chamada Tabela de graus que foi instaurada por Pedro o Grande.

Nela ficavam estabelecidos todos os graus militares e seus equivalentes no serviço civil. A tabela de graus vigorou até a revolução de 1917 (N. de T).

${ }^{200}$ Conforme nota da edição espanhola, trata-se do cavalo de Tolstói (N. do T.).

${ }^{201}$ No dia 13 de junho de 1853, ao separar-se do destacamento, indo de Vozdvijenskaia em direção à fortaleza de Gróznaia, Tolstói, com Sado, um amigo de tchetchenos russos, tropeçou nas montanhas com um grupo de tchetchenos armados e quase se salvou da perseguição.

${ }^{202}$ Obri é o herói do romance de Samuel Warren Dez mil por ano (1839). O romance foi publicado com o título O litígio, no Otiétchestvennye Zápiski (anales) de 1852, $\mathrm{N}^{\circ} 11-12$ e de $1853, \mathrm{~N}^{\circ} 1-10$. A referência a Shakespeare corresponde às palavras de Nestor no ato terceiro, cena primeira de Troilo e Créssida. Tolstói fez anotações do romance onde Obri pronuncia essas palavras.
} 
me tão mal. Se eu aguardar circunstâncias nas quais me seja fácil ser virtuoso e feliz, nunca (deixarei) de esperar: estou convencido disso.

25 de junho. Hoje recebi uma carta de Serioja onde me escreve que o príncipe Gortchakov quer escrever sobre mim a Vorontsov e umas linhas sobre a demissão. Não como acabará tudo isto; mas eu tenho a intenção de ir para Piatigorsk em uns dias.

Não tenho coerência nem constância em nada. Por causa disso, neste último tempo em que comecei a prestar atenção a mim próprio, tornei-me insuportavelmente vil para mim. Se tivesse coerência com a orientação vaidosa com a qual cheguei aqui, eu teria sido exitoso no serviço e teria uma desculpa para estar satisfeito de mim. Se fosse conseqüente com a orientação virtuosa com a qual permaneci em Tíflis, eu poderia desprezar meus fracassos e, de novo, estaria satisfeito de mim. Do mais mínimo ao mais grande, este defeito destrói a felicidade da minha vida. Se fosse conseqüente com a minha paixão pelas mulheres, eu teria êxito e recordações. Se fosse conseqüente com minhas abstinências, eu estaria orgulhosamente tranqüilo. Este maldito destacamento, desviou-me completamente do verdadeiro caminho do bem no qual tinha entrado tão bem e para o qual desejo entrar de novo, apesar dos pesares, porque ele é o melhor. Senhor, ensina-me, instrui-me.

Não posso escrever. Escrevo demasiado devagar e mal. E o que mais posso fazer além de escrever? Agora reflito sobre a minha situação. Passa-me pela cabeça tal quantidade de variados pensamentos que por muito tempo não pude lembrar nada exceto que sou mau e infeliz. Depois desse tempo de penosa meditação, formou-se na minha cabeça a seguinte ideia: O objetivo da minha vida está determinado - é o bem, pelo qual tenho obrigação para com meu súbdito e meus compatriotas. Com o primeiro tenho obrigação porque sou seu dono; com os segundos porque possuo talento e inteligência. Estou agora em disposição de cumprir a última obrigação e para cumprir a primeira, eu devo usar todos os meios que dependerem de $\operatorname{mim}$.

Minha primeira ideia foi traçar-me regras para a vida e agora eu, sem querer, volto a ela. Mas quanto tempo eu perdi de balde! Tal vez Deus tenha arranjado a minha vida assim, com o objetivo de dar-me mais experiência. É pouco provável que tivesse compreendido meu objetivo se tivesse sido feliz na satisfação das minhas paixões. Determinar por antecipado minhas ações e comprovar sua execução foi uma ideia boa e volto a ela. A partir desta noite, sem importar em que circunstâncias eu estiver, dou-me a palavra de cumprir isso cada noite. Com freqüência, a falsa vergonha obstaculizou-me nisso. Dou-me a palavra de superá-la o 
quanto for possível. Sê direto, embora rude, mas franco com todos, mas não com franqueza pueril, sem necessidade. Abstém-te do vinho e das mulheres.

O deleite é tão pouco, tão confuso, e o arrependimento tão grande! $A$ cada trabalho que fizeres, entrega-te por completo. Diante de cada sensação forte, abstém-te da ação e, uma vez tenhas refletido, embora erroneamente, age com decisão.

Amanhã. Levantar-me cedo, escrever Adolscência até o almoço - depois do almoço ir à casa dos ucranianos e buscar a oportunidade de fazer uma boa ação, depois, escrever "O diário de um oficial caucasiano" 203 ou $O$ fugitivo $^{204}$ - até a hora do chá. Dar uma corrida. Escrever Adolscência ou "Regras para a vida".

29 [de junho]. Pela manhã me comportei bem, mas depois do almoço não fiz nada. O tão bem pensado plano para as "Anotações de um oficial caucasiano" me pareceu mau, e eu me passei todo o tempo depois do almoço com as crianças e com Iapichka. Empurrei Grichka e Vaska para a água. Mal. Bem ou mal, sempre devo escrever. Se escreves, acostumas-te ao o trabalho e formas o estilo, embora sem um proveito imediato. Se não escreves, distrais-te e fazes bobagens. Escreve-se melhor em jejum [...].

8 de junho. Levantei-me tarde. Tinha começado a escrever, mas não saiu. Estou demasiado insatisfeito da minha vida sem objetivo e desordenada. Estive lendo a Profession de foi Du Vicaire Savoyard e, como sempre com esta leitura, nasceu em mim uma profusão de ideias sensatas e úteis. Sim, minha principal infelicidade é ser muito inteligente. Dormi depois do almoço, joguei um pouco com as crianças e fiz tão mal que não só não detive senão que dei motivo para envergonhar Iapichka.

Não posso demonstrar a mim mesmo a existência de Deus, nem encontro uma só prova sensata e acho que essa concepção não é necessária. É mais fácil e mais simples compreender a existência eterna de todo o mundo com sua maravilhosa ordem incompreensível do que compreender o ser que o criou. A inclinação da carne e da alma do homem para a felicidade é o único caminho para a compreensão dos mistérios da vida. Quando a inclinação da alma colide com a inclinação da carne, a primeira deve levar vantagem pois a alma é imortal assim como a felicidade que ela alcança. A realização da felicidade é o caminho para seu desenvolvimento. Os vícios da alma são nobres inclinações

\footnotetext{
${ }^{203}$ Nome original do conto "A derrubada do bosque".

${ }^{204}$ Nome original da novela Os cossacos.
} 
que se corromperam. A vaidade é o desejo de estar satisfeito consigo. A cobiça é o desejo de fazer um bem maior. Não compreendo a necessidade da existência de Deus, mas acredito nele e peço-lhe que me ajude a entendê-lo.

9, 10, 11, 12, 13, 14, 15 de julho [Piatigorsk ${ }^{205}$ ]. Fui embora de Starogladkóvskaia sem o menor pesar. O caminho de Arslan-Khan desgostou-me mortalmente. Ao chegar a Piatigorsk, encontrei Macha absorta no mundo local. Foi doloroso para mim ver isso, não penso que por inveja, mas foi desagradável abandonar a convicção de que ela é, exclusivamente, uma mãe de família. Além disso, ela é tão inocentemente adorável que, (ainda) na vil sociedade local, permanece nobre. Enviei cartas a: Bariatínski - boa, Brimmer satisfatória e Mooro - ruim. Valerian é sensato e puro, mas não há nele aquele delicado sentimento de nobreza que, para mim, é necessário para ficar íntimo de uma pessoa. Baron ${ }^{206}$ é um homem bom. Como faltam a Valerian e Nikólenka o tato para não rir do aspecto e modos das pessoas, quando eles próprios são tão ruins a esse respeito. Em geral era para mim penoso e triste. Eu não experimentarei esse sentimento, tenho certeza, depois de ter me encontrado com Serioja e ainda mais com Tatiana Aleksándrovna.

23 se julho. Reescrevi o primeiro capítulo satisfatoriamente ${ }^{207}$. Estive em casa de Macha por pouco tempo. Trabalho, trabalho! Como eu me sinto feliz quando trabalho.

24 de julho. Levantei-me às 8 , corrigi o $1^{\text {ro }}$ capítulo e não escrevi nada no dia inteiro, estive lendo Claude Genoux ${ }^{208}$. Fui à casa de Macha; lá é muito enfadonho. Bulka está perdido. Recebi uma carta de Mooro: Brimmer retardou a minha demissão.

Levantar-me cedo e escrever sem deter-me naquilo que parecer fraco, só porque parece sensato e fácil. Corrigir é possível, mas o tempo perdido sem proveito não volta.

25 de Junho. Exceto pelas três horas que passei no bulevar, trabalhei o dia inteiro; mas apenas reescrevi 1 1/2 capítulo(s). "Nova percepção"209 é forçado, mas "A tempestade" magnífico [...].

\footnotetext{
${ }^{205}$ No dia 9 de Julho, Tolstói partiu para Piatigorsk onde, por essa época, encontrava-se sua irmã Maria Nikoláievna com seu esposo.

${ }^{206}$ I. E. Felkerzan.

${ }^{207}$ Primeiro capítulo de Adolescência.

${ }^{208}$ Provavelmente seja um erro. Deve ler-se Claude Gueux, romance de Victor Hugo, Paris, 1834.

${ }^{209}$ Terceiro capítulo de Adolescência.

${ }^{210}$ Segundo capítulo de Adolscência.
} 
27 [de julho] [...] Li as Anotações de um caçador de Turguêniev e como é difícil escrever depois dele. Escrever o dia inteiro.

26 [de agosto. Jeleznovodsk]. Não fiz nada. Resolvi-me a deixar Adolescência mas, continuar o romance ${ }^{211}$ e escrever os contos caucasianos ${ }^{212}$. A causa da minha preguiça é que não posso escrever com paixão. Eu aguardo não sei que felicidade neste mês e, em geral, dos meus 26 anos de idade. Quero obrigar-me a ser tal como, conforme minhas ideias, deve ser o homem. A juventude foi embora. Agora é tempo do trabalho.

28 [de agosto. Piatigorsk] [...] Pela manhã, comecei uma novela cossaca ${ }^{213}$, depois, para a chegada de Nikólenka e a partida dos Teodorin e o meu aniversário, fui ao tiro e à colônia e levei Macha ao bulevar. Não estive alegre. Só o trabalho pode dar-me prazer e proveito. Deito-me para dormir, vou ler.

10 de setembro [Piatigorsk] Não fiz nada, estive conversando com Macha, fiz planos para uma vida todos juntos em Moscou. A preguiça e a consciência da preguiça atormentamme terrivelmente. Amanhã vou trabalhar ainda que seja uma porcaria, mas só para estar satisfeito de mim, porque esta vida com um arrependimento constante é um suplício!

13 de setembro. Pela manhã era uma melancolia terrível [...] Depois me veio a ideia “Anotações do marcador”, maravilhosamente bem. Estive escrevendo, fui ver a reunião e, de novo, estive escrevendo “Anotações do marcador”. Parece-me que só agora escrevo por inspiração e por causa disso está bem.

14 de setembro. Terminei o rascunho e à noite escrevi uma folha em limpo. Escrevo com tal paixão que me é difícil continuar: o coração se me pára. Tremendo, ponho-me a escrever. Amanhã virão Valerian e Macha.

\footnotetext{
${ }^{211}$ Romance de um proprietário russo.

${ }^{212}$ Conto "A derrubada do bosque".

${ }^{213}$ A novela $O$ foragido (fugitivo), depois chamada Os cossacos.
} 
18, 19 [de setembro] Não fiz nada, hoje havia começado a escrever, mas a preguiça venceu, à noite estive em casa de Smychliaeva e escrevi versos ${ }^{214}$.

O humor só é possível, caso o homem estiver convencido de que seus pensamentos não expressados ou expressados de forma estranha, serão compreendidos. Ele (o humor) depende da situação e mais ainda dos ouvintes ou da opinião instintiva sobre os ouvintes.

29 [de setembro]. Pela manhã, escrevi um capítulo de Adolescência; bem. Depois do almoço, cavalguei das 6 às 8 horas. Estive em casa de Aksínia. Ela é boa, mas não me agrada tanto como antes. Propus a ela levá-la comigo. Parece-me que aceitará. Em "A morte da avó" 215 pensei no traço característico de religiosidade junto com o não perdão das ofensas.

13 [de outubro. Starogladkóvskaia] Estive de caça, escrevi cartas a Máslov e Baráchkin. Matei dois faisões. Hoje li a característica literária do gênio ${ }^{216}$ e essa obra despertou em mim a certeza de que sou um homem com capacidades extraordinárias e zelo pelo trabalho. A partir de hoje começarei. Pela manha, escrever Adolescência e $O$ foragido (fugitivo) depois do almoço e à noite. Ideias sobre a felicidade.

22 de outubro. Levantei-me tarde. Escrevo um pouco até a hora do almoço, depois do almoço estive em casa de Groman, aonde chegou também um oficial do regimento de Samurski, e contou, de forma muito divertida, sobre o assunto em Zaqatala ${ }^{217}$. Depois escrevi, apesar da presença de moleques e depois do almoço joguei cartas. Adolescência me repugna ao máximo. Espero terminar amanhã. A ideia de escrever em livros diferentes meus pensamentos, observações e regras é muito estranha. É muito melhor escrever tudo no diário, e esforçar-me em escrever de forma regular e limpa para que ele seja, para mim, um trabalho literário e para que possa ser, para os outros, uma leitura agradável. No fim de cada mês, ao revisá-lo, posso escolher e extrair o que achar notável. Para facilidade, vou fazer um pequeno índice de cada dia em folhas separadas.

23 de outubro. Acordei hoje muito tarde e com aquela aborrecida disposição de espírito [...] A má disposição de espírito e o desassossego impediram-me trabalhar. Li

\footnotetext{
${ }^{214}$ Versos desconhecidos.

${ }^{215}$ Capítulo 23 de Adolscência.

${ }^{216}$ Esboço do trabalho de Benjamin Disraeli O caráter literário ou história do génio adoptada (apropriada) dos seus próprios sentimentos e reconhecimento - sobre a vida de pessoas notáveis (Sovremiênnik, 1853, № 5-11). Nesse dia, Tolstói leu o $\mathrm{N}^{0} 8$ da revista.

${ }^{217}$ Cidade e centro administrativo da região do mesmo nome, localizada no norte do Azerbaijão (N. de T.).
} 
Nádenka, a novela de Jukovoi ${ }^{218}$. Antes me era suficiente saber que o autor do romance era uma mulher para não o ler, porque nada pode ser tão ridículo como a visão da mulher sobre a vida do homem que, com freqüência, elas se põem a descrever; Ao contrário, já na esfera feminina o autor-mulher tem enorme vantagem sobre nós. Nádenka é muito cuidadosamente realizada mas a sua personalidade é esboçada de forma demasiado ligeira e indefinida. É evidente que o autor não foi conduzido por nenhuma ideia.

Eu me debruço sobre o meu caderno de Adolscência, com uma certa repugnância desesperada, como um trabalhador obrigado a labutar com uma coisa que, na sua opinião, não tem utilidade nem presta em lugar nenhum. O trabalho está indo descuidadamente, com frouxidão e preguiça.

Uma vez terminado o último capítulo, será necessário revisar tudo desde o começo e fazer anotações e um rascunho das mudanças definitivas. É conveniente mudar muita coisa: o caráter do "Eu" é frouxo, a ação muito prolongada e conseqüente com o tempo, mas inconseqüente com o pensamento. Por exemplo, o método de descrever, no meio da ação, para clareza, e enchimento do conto com eventos passados, e com a minha divisão de capítulos, absolutamente descuidado. Durante todo o tempo do almoço e depois, não consegui e não tive necessidade de vencer a apática melancolia que se apoderara de mim.

“Contentar-se com o presente". Esta regra lida por mim hoje surpreendeu-me extraordinariamente.

Eu me lembro, vivamente, de todos os casos na minha vida em que não a segui e pareceu muito admirável que eu não a tivesse seguido. Por exemplo, nos mais recentes acontecimentos no meu serviço, eu queria ser junker-conde, rico, com relações, um homem notável quando o mais útil e propício para mim teria sido ser junker-soldado. Então, quanto de interessante eu poderia ter reconhecido nesse tempo e quanto de desagradável poderia ter evitado.

24 de Outubro. Levantei-me mais cedo do que ontem e sentei-me a escrever o último capítulo. Muitos pensamentos se amontoaram, mas não sei que repugnância invencível impediu-me de terminá-lo. Como em toda vida, também na criação, o passado condiciona o futuro: é difícil continuar com entusiasmo uma obra abandonada e, conseqüentemente, fazê-lo

\footnotetext{
${ }^{218}$ Novela Nádenka de M. S. Jukovoi publicada no Sovremiênnik, 1853, No 8.
} 
bem. Tenho pensado algumas mudanças em Adolescência, mas não fiz nenhuma. Devo fazer anotações com mão ligeira e, simplesmente, começar de novo a reescrever.

Até o almoço, estive lendo a crítica sobre a descrição da guerra de 1799 entre a Rússia e a França ${ }^{219}$ e, depois do almoço, sem nenhuma vontade, fui atirar ao alvo com Groman. O tempo maravilhoso me seduziu e fui de caça, matei uma lebre e estive correndo atrás de um chacal-dourado até tarde à noite. Depois do jantar, joguei baralho até as 12 horas. Quão fácil se tornam ruins os costumes! Já estou eu acostumado a jogar baralho depois do jantar.

Ao ler uma obra, em especial uma puramente literária, o interesse principal o constitui o caráter do autor expressado na obra. Mas há também tais obras em que o autor afeta sua visão ou a modifica algumas vezes. As mais agradáveis são aquelas em que parece que o autor se esforça em ocultar sua visão e, ao mesmo tempo, permanece constantemente fiel a si próprio onde quer que apareça. Os mais insossos são aqueles em que a visão muda com tanta freqüência, que se perde por completo.

25 de outubro. Pela manhã, revisar Adolescência e decidir reescrevê-la ou acerca das mudanças e acréscimos que é necessário fazer nela. Por volta das 10 fui de caça e fiquei passeando até à noite. Li o novo e muito ruim Sovremiênnik ${ }^{220}$. Jantei e agora vou me deitar. Hoje, o dia inteiro foi para mim de descanso moral, necessidade que, com tanta freqüência, reconheço inconscientemente.

Eu começo a lamentar ter enviado demasiado apressadamente "As anotações do marcador". No que se refere ao conteúdo, é pouco provável que eu encontre muito que mudar ou acrescentar às anotações. Mas a forma não está, em absoluto, acabada com esmero.

26 de outubro. Levantei-me tarde e com dor de cansaço em todos os membros. Desde cedo, trabalhei bastante bem na cópia datilografada e na organização de Adolescência mas, me chamaram logo para almoçar e, depois do almoço, havendo lido um pouco e conversado com Aleksiéev que veio ter comigo, fiz muito pouco.

\footnotetext{
${ }^{219}$ Trata-se da resenha de A. P. Kartsov sobre os tomos IV e V do trabalho de D. A. Miliutin História da guerra da Rússia contra a França durante o reinado do Imperador Pável I, em 1799”, publicada em 5 tomos (S. P. 6), ( "Sovremiênnik", 1853, N 6).

${ }^{220}$ Tolstói leu o Savremiénnik (O contemporâneo) N ${ }^{\circ} 8$.
} 
A descrição da luta do bem contra o mal no homem que tenta ou acaba de fazer uma má ação sempre me pareceu artificial. O mal se faz com facilidade e sem ser notado, e só muito depois o homem se espanta e admira daquilo que fez.

O povo simples é tanto mais digno do que nós no cumprimento de seu trabalho e nas privações da vida, que não está bem buscar e descrever no nosso irmão o que é mau. Isso existe nele, mas seria melhor dizer sobre ele (como se diz sobre os mortos) algo bom. Essa é uma qualidade de Turguêniev e um defeito de Grigórovitch e seu "Dos pescadores"221. A quem podem interessar os vícios desta classe miserável e digna? Nele há mais bem do que mal; por isso, é mais natural e nobre buscar as causas do primeiro do que do segundo.

$\mathrm{Eu}$ antigamente pensava que, tendo de si para consigo, a regra de ser firme e cuidadoso nas suas ocupações, poderia seguir essa regra; depois de muitas vezes repetidas e nunca cumpridas com exatidão, essas regras começaram a convencer-me de serem inúteis. Já agora me convenço de que estes acessos que constantemente se enfraquecem e de novo se reiniciam constituem a disposição normal da consideração periódica de si próprio.

É necessário habituar-se sempre e em tudo a escrever com exatidão e clareza porque com freqüência e inconscientemente, oculta-se de si mesmo a imprecisão e inexatidão do pensamento por meio de expressões afetadas, borrões e rasuras.

28, 29, 30 de outubro, 31 de outubro e 1 de novembro [Khasav Yurt ${ }^{22}$ ] 28 e 29. Fiquei nessa consciente e pesarosa falta de ação que provém do constante ocupar-se de uma ideia desagradável. No dia 29, fui o dia inteiro de caça, conversei com Iepichka, joguei cartas e li a biografia de Schiller escrita pela sua cunhada ${ }^{223}$.

É extraordinariamente notável nela a visão superficial que, de um homem grande, tem uma mulher sentimental e uma pessoa que, pelo fato de estar demasiado próxima do poeta, encontra-se sob a influência dos mesquinhos defeitos domésticos que lhe fazem perder o devido respeito ao poeta.

\footnotetext{
${ }^{221}$ Romance de Dmitri Vassílevitch Grigórovitch Os pescadores (Sovremiênnik, 1853, No 3, 5, 6 e 9). Nesse mesmo ano apareceu em publicação avulsa.

${ }^{222}$ Khasav Yurt, fortificação localizada 40 verstas ao sul da stanitsa Starogladkóvskaia.

${ }^{223}$ Tolstói leu o primeiro artigo do trabalho de Caroline von Wolzogen "Schiller e a sua correspondência com os seus amigos" (Sovremiênnik 1853, No 8).
} 
31 [de outubro] Li $A$ filha do capitão e ai! Tenho que reconhecer que agora a prosa de Púchkin já é velha, não pelo estilo, mas pela forma da narração. Agora, justamente, na nova tendência, o interesse pelos detalhes do sentimento substitui o interesse pelos próprios acontecimentos. As novelas de Púchkin são um tanto pobres. Eis as ideias que me ocorreram durante estes quatro dias e que consegui anotar, para memorizar, numa pequena caderneta.

É impossível seguir as determinações da vontade racional, só como conseqüência de sua expressão. É necessário utilizar ardis contra as próprias paixões. Para cada um é agradável fazer o bem, mas as paixões obrigam-nos, com freqüência, a vê-lo sob uma luz falsa. E a razão, ao agir irregularmente, é fraca contra as paixões; ela deve esforçar-se em agir uma na outra. Nisso consiste a sabedoria.

Schiller, com justeza absoluta, descobriu que nenhum gênio pode desenvolver-se em solidão, que os estímulos externos -um bom livro, uma conversa- fazem avançar mais a reflexão do que anos de trabalho solitário ${ }^{224}$. O pensamento deve nascer em sociedade, mas sua elaboração e expressão originam-se em solidão.

Uma das causas principais dos erros da nossa classe rica consiste em que não nos acostumamos logo à ideia de que somos adultos. Toda a nossa vida, até os 25 e mais, contradiz esta ideia. Completamente ao contrário do que acontece na classe camponesa, em que um rapaz de 15 anos se casa e se torna um perfeito patrão. Freqüentemente me surpreendeu a autonomia e confiança desse rapaz que, embora seja um garoto sensato, na nossa classe seria uma nulidade.

É estranho que todos nós ocultemos que uma das "molas" mais importantes da nossa vida é o dinheiro. Como se fosse uma vergonha. Pegue-se um romance, uma biografia, uma novela: por toda a parte esforçam-se em evitar as questões pecuniárias, apesar de que nelas está o principal interesse (e se não o principal, pelo menos o mais constante) da vida e se expressa melhor o caráter do homem.

\footnotetext{
${ }^{224}$ Friedrich Schiller expressou essas ideias em carta de 21 de Fevereiro de 1783 a Reinwald de Meiningen. Tolstói leu sobre isso no artigo de Caroline von Wolzogen.
} 
Existe uma classe de amáveis, nobres (embora a maior parte seja desgraçada na vida e desrespeitada) que parece que só vivessem à espera da ocasião de sacrificar-se por outro ou pela honra e que só vivem desde o momento em que se inicia esse sacrifício.

Com freqüência, tem me acontecido ficar admirado e invejar a sólida e precisa visão das pessoas que têm lido pouco.

Revisar qualquer rascunho terminado de uma composição, riscando tudo o supérfluo e sem acrescentar nada. Este é o primeiro processo.

Ao ler o conto de uma certa grã-senhora inglesa ${ }^{225}$, espantou-me a desenvoltura dos seus procedimentos, que eu não tenho, e para adquirir a qual, preciso trabalhar e observar.

Existem pessoas, ao número das quais pertenço eu e aqueles que eu quero mostrar no herói do Romance de um proprietário russo, que sentem que devem parecer orgulhosos e quanto mais se esforçam em mostrar no rosto uma expressão de indiferença, mais parecem arrogantes.

Com freqüência, em uma obra me detêm os métodos de expressão rotineiros, não completamente corretos, nem sólidos, nem poéticos; Mas o costume de encontrá-los com freqüência obriga a usá-los. Estes freqüentes procedimentos irreflexivos em um autor [?], são defeitos que se sentem mas que se perdoam e que, por causa do uso recorrente, servirão à futura geração como prova do mau gosto. Conformar-se com esses procedimentos, significa acompanhar uma época, corrigi-los significa ir à sua frente.

2, 3 de novembro Ontem começou uma disputa entre alguns oficiais e eu sobre o valor de uns títulos concedidos; aconteceu que Zuev manifestou, sem qualquer lógica, a sua inveja pelo meu título. Nesse minuto, a ideia de que ele me considerasse vanglorioso do meu título espicaçou meu amor-próprio. Agora me alegra de coração que ele tenha me permitido confirmar em mim essa fraqueza. Quão perigoso é acreditar nas ideias que surgem ao calor da disputa.

Viver sempre sozinho: regra querida que me esforçarei em guardar.

\footnotetext{
${ }^{225}$ Provavelmente o romance (conto) de Harriet Beecher Stowe, traduzido para o português como $A$ cabana do pai Tomas (Sovremiênnik, 1853, No 9).
} 
Quase toda vez, antes do encontro com uma pessoa nova, experimento um pesaroso sentimento de decepção. Eu o imagino tal como sou eu e o estudo calculando a partir dessa medida. Devo acostumar-me, de uma vez e para sempre, à ideia de ser uma exceção, ou bem estou adiantado à minha época ou sou uma dessas absurdas e intratáveis naturezas que nunca estão satisfeitas. É necessário tomar outro padrão inferior ao meu e com ele medir as pessoas. Vou errar raras vezes.

Enganei-me por muito tempo, imaginando que eu tinha amigos, pessoas que me compreendiam. Que absurdo! Ainda não encontrei nem um só homem que fosse moralmente tão bom quanto eu, que acreditasse em que, na vida, não me lembro de uma ocasião em que não tenha sido atraído pelo bem e em que não tenha estado prestes a sacrificá-lo tudo por ele.

Daí que eu não conheça uma sociedade que pudesse ser leve para mim. Sempre sinto que a expressão das minhas ideias íntimas será tomada por uma falsidade e que não podem simpatizar com os interesses particulares.

5 de novembro. Os dentes me doeram de manhã tanto assim que não pude dormir e levantei-me cedo. Comecei a revisar Adolescência mas, exceto pelas rasuras, não fiz nada.

Estou absolutamente convicto de que devo conseguir a glória; até por isso trabalho tão pouco: estou persuadido de que só tenho que querer elaborar os materiais que sinto em mim.

\section{7, 8, 9, 10, 11, 12, 13, 14, 15 [de novembro. Starogladkóvskaia] Deixei a Akrchiévski} quase a metade de Adolescência para o datilografado. Perdi 42 rublos de Sokovnin e fui embora de Khasav-Yurt deixando perto de 10 rublos em dívidas.

Os visitantes não me deram nem um minuto de sossego, assim que me deixaram completamente desorientado.

Eu nunca revelei meu amor mas, ao lembrar-me das terríveis tolices com que enganei as pessoas que me agradavam, com um sorriso fino e complicado, eu fico corado da só lembrança. As conversas que se lêem nos nossos nobres romances pour tout de bom ${ }^{226}$,

\footnotetext{
${ }^{226}$ Em sério (em francês no original).
} 
parecem-se a elas como duas gotas de água. É necessário convencer-se de que a ociosidade e a vida desarranjada (isto é, sem ordem) não é só prejudicial para os assuntos cotidianos senão que pode se a causa dos mais terríveis vícios e ações da minha parte, tal como o experimentei hoje. Sou tão fraco! Deve-se temer a ociosidade e a desordem tanto como eu temo as cartas.

[16 de novembro] 15. Levantei-me cedo e pus-me a escrever, mas, apesar da abundância de ideias e o esmero da escritura, escrevi extremamente pouco.

Houve uma época em que a consciência se desenvolveu em mim até um grau tal que abafou a razão de modo que eu não posso pensar em nada exceto: no que eu penso?

Com freqüência, espantou-me que possam as pessoas deleitar-se interiormente com as suas frases sem sentido, com umas palavras. Talvez, em um certo grau de desenvolvimento, a inteligência simpatiza com as palavras exatamente como no grau mais alto simpatiza com as ideias. Iepichka diz que, para falar de forma inteligente é necessário parar junto à vassoura, isto é virar-se para o canto e pensar um pouco.

17, 18 de novembro. Ontem me levantei cedo mas escrevi pouco. Dois capítulos, "A donzela" e "Adolescência" que há tanto tempo não consigo trabalhar definitivamente, demoraram-me. Almocei, joguei xadrez mal e ainda me vangloriei.

Peguei a história de Karamzin ${ }^{227}$ e li alguns fragmentos dela. O estilo é muito bom. $\mathrm{O}$ prefácio despertou em mim uma multidão de boas ideias ${ }^{228}$. Hoje espanquei Aliochka. Embora ele fosse culpado, não estou satisfeito de mim por ter me irritado (esquentado).

Os cossacos dizem: isto é um fuzil, e pobre é usado em um sentido carinhoso: condolências carinhosas. Nos tempos de Catarina as pessoas chamavam os empregados como crianças mimadas.

\footnotetext{
${ }^{227}$ Nikolai Karamzin (1766 - 1826), historiador, escritor, poeta, membro honorário da Academia de Ciências de São Petersburgo. A obra aqui mencionada por Tolstói é a História do Estado Russo, obra em 12 volumes escrita entre os anos 1803 - 1826, considerada um dos primeiros trabalhos integrais de história da Rússia (Informação disponível em:

http://ru.wikipedia.org/wiki/\%D0\%9A\%D0\%B0\%D1\%80\%D0\%B0\%D0\%BC\%D0\%B7\%D0\%B8\%D0\%BD, \%D0\%9D\%D0\%B8\%D0\%BA\%D0\%BE\%D0\%BB\%D0\%B0\%D0\%B9 \%D0\%9C $\%$ D0\%B8\%D1\%85\%D0\%B 0\%D0\%B9\%D0\%BB\%D0\%BE\%D0\%B2\%D0\%B8\%D1\%87 último acesso 15/07/09. N. do T).

${ }^{228}$ No prefácio à História do Estado Russo de Karamzin, ficam determinados o objetivo e tarefas da história como ciência.
} 
Existem nomes próprios, nomes de coisas, animais e pessoas, que esboçam os costumes de um determinado círculo melhor que uma descrição. Por exemplo, um touro Alekseitch, uma caixa - cofre da avó.

Iapichka finalmente me explicou o crescimento imaginário do Terek. Ele já foi mais estreito e mais profundo. Já agora, ao desviar-se das montanhas, mudar seu leito e achar um fundo mais firme ele se torna mais largo.

Esta também é uma boa canção que ele me disse:

Na gloriosa cidade, em Kiev

o glorioso príncipe Vladímir teve

houve uma vez uma donzela, alma bela

Pecou esta donzela, pecado mortal

concebeu a donzela um jovem

isto é, Alexandre o grande

por causa dessa desonra a donzela

da cidade saiu

Ela foi-passou, nem por vereda, nem por caminho

Mas foi-passou por trilha feroz

Ao encontro da bela donzela, o bom e valente

O bom e valente Ilyá Muromets

Pôs-se a perguntar com insistência à bela donzela

De que avoengo és tu, bela donzela

Sim, eu sou donzela de não simples avoengo

Bela donzela do bogatyr ${ }^{229}$.

Acontece-me, de repente, sentir que, por esquecimento, fico com uma fisionomia de assombro ainda quando não há já causas para assombrar-se (No capítulo “O concerto”). ${ }^{230}$

Alguém contou a Iepichka que, supostamente, eu entreguei um homem aos soldados por ele ter estrangulado meu cachorro. Uma calúnia tão horrível sempre me confirma a nobre

\footnotetext{
${ }^{229}$ Bogatyr é o herói das Bylinas, poemas épicos russos da tradição oral.

${ }^{230}$ Suposto capítulo de Adolescência. (Предполагавшаяся глава «Отрочество».)
} 
ideia de que fazer o bem é o único meio de ser feliz. Se só se olha a vida desde outra perspectiva - que não seja essa-, uma calúnia dessas arruína toda a felicidade da vida.

É como si algumas pessoas se enganassem a si próprias ao esforçar-se em falar sobre seu estilo de vida passado ou futuro, mas não do presente.

Nada impede tanto a felicidade verdadeira (constituída pela vida virtuosa) como o costume de esperar alguma coisa do futuro, enquanto que, para a felicidade verdadeira, consistente na auto-suficiência interior, o futuro nada pode dar; tudo é dado pelo passado.

Quanto mais jovem é o homem, menos acredita no bem; não obstante, ele é mais crédulo no mal.

19, 20, 21, 22 [de novembro] Eu, parece, errei as contas, porque, decididamente, não consigo lembrar o que eu fiz durante esses quatro dias.

Um dos mais importantes e, para mim, mais desagradáveis dos meus vícios é a mentira. A causa impulsora é, em maior parte, a vanglória, o desejo de manifestar-me desde uma posição vantajosa. Por isso, para não permitir-me chegar a esse grau de desenvolvimento da vaidade, no qual já não há tempo de parar e voltar a refletir, estabeleço-me a seguinte regra: assim que sentires a coceira do amor-próprio, o desejo precedente de contar algo sobre si, volta a refletir (pensa duas vezes). Cala e lembra que nenhuma invenção te dará, aos olhos dos outros, mais peso do que a verdade que, para todos, possui um caráter palpável e convincente.

Cada vez que sentires enfado e raiva, evita qualquer trato com as pessoas, especialmente aquelas que dependam de ti. Fugir do meio das pessoas que gostam de bebedeiras e não bebas nem vinho, nem vodka.

De 23 de outubro a 1 de dezembro. Estive algumas vezes de caça, matei lebres e faisões. Quase não li nada, nem escrevi durante todos estes dias. A espera de uma mudança de vida perturba-me ${ }^{231}$ e o capote cinza é-me tão repugnante que me dói moralmente vesti-lo, como não era antes. Ontem passou por aqui Sultanov. Recebi de Arslan-Khan há três dias

\footnotetext{
${ }^{231}$ Tolstói fala aqui sobre a promoção para o grau de oficial e a transferência (перевод в Дунайскую армию) para o Exército do Danúbio.
} 
uma carta e um sabre. As regras estabelecidas, justamente a de não beber, foram traídas a cada dia.

Apesar de Iapichka não ser um homem velho e de ele ter tido contato com a educação, por causa da sua vida solitária, ou por outros motivos, é difícil achar um homem de caráter mais antiquado, especialmente no seu discurso.

Com freqüência, a modéstia começa com fraqueza e irresolução, mas, quando a experiência demonstrar às pessoas que elas erraram, então a modéstia dará novo encanto, força e respeito ao caráter.

(Schiller) Para algumas pessoas, o fogo da inspiração transforma-se em uma luz de trabalho útil. O êxito literário que deleita a si próprio, obtém-se só mediante o cultivo de todos os aspectos do objeto. Mas o objeto deve ser elevado para que o trabalho seja sempre agradável $^{232}$.

Quanto mais o homem se acostuma ao agradável e elegante, mais privações prepara para si próprio na vida. De todos esses costumes, a privação dos costumes referentes apenas ao aspecto elegante da inteligência, é o mais difícil.

Vladímir pôde converter seu povo para a fé que ele tinha adotado só porque ele estava no mesmo grau de formação que eles, ainda que em posição mais elevada em importância social. O povo creditava nele. Nenhum outro governante de um Estado culto, seria capaz de fazer o mesmo.

Em poucas palavras, em um dos seus relatos, Iepichka expressou de maneira excelente a opinião dos cossacos sobre a importância das mulheres. "Tu, esposa, és serva, então, trabalha -diz o marido à mulher-, eu me vou de farra".

Boa também uma conversa que escutei, por acaso, sobre o inverno:

A. Hoje o inverno vem do mar. B. Sim, ele cobre tudo sob suas asas. Cossaco, em tártaro significa solteirão.

\footnotetext{
${ }^{232}$ Palavras de Friedrich Schiller em carta a Charlotte von Lengefeld (com quem se casaria no ano seguinte) de 30 de abril de 1789. Tolstói copiou-as do terceiro artigo de Caroline von Wolzogen (Sovremiênnik, 1853, № 10, pag. 164.
} 
2 de dezembro. Levantei-me de boa vontade, queria dedicar-me a Adolescência mas, sem os cadernos anteriores, pareceu-me inconveniente. Ainda não se resolveu nada de novo. Coloquei em ordem meus papéis e cartas, almocei em casa, li Otiétchestvennye Zápiski. Depois do almoço, falei e joguei xadrez com o insuportável Olifer, li e vou me deitar com um certo resfriado já forte.

Regra sobre (contra) a preguiça - Ordem na vida, ordem nas atividades intelectuais e fïsicas.

Há dois desejos cuja realização pode constituir a felicidade de um homem: ser útil e ter a consciência tranqüila.

A vaidade provém e fortalece-se com a desordem moral na alma do homem. Antes eu apenas compreendia instintivamente, pressentia a necessidade da ordem em tudo. Só agora a entendo.

Após ter concluído Adolescência, resolvi agora escrever uns pequenos contos, tão curtos, que eu possa inventá-los de uma só vez, e tão elevados e de conteúdo tão útil, que eles não possam nem enfastiar-me nem repugnar-me. Além disso, às noites vou compor, por escrito, o plano de um grande romance e esboçar algumas cenas dele.

3 de dezembro. Levantei-me cedo, mas não posso começar nada. O conto cossaco agrada-me e também não me agrada.

Eu tenho um grande defeito - a incapacidade de relatar de forma simples e fácil as circunstâncias do romance relativas às cenas poéticas.

Estive hesitante em relação à escolha entre quatro ideias para (os) relatos: 1) "O diário de um oficial caucasiano", 2) o poema cossaco, 3) A dança húngara ${ }^{233}$, 4) O homem fracassado $^{234}$. As quatro ideias são boas. Começarei pela que parece menos complexa, fácil e a primeira no tempo - "O diário de um oficial caucasiano".

$11,12,13,14,15,16$ [de dezembro]. O resfriado e a dor de garganta não cessam. Por duas vezes, tive a imprudência de ir de caça (com Sulimóvski). Há três dias chegou Aleksiéev.

\footnotetext{
${ }^{233}$ O projeto não foi executado.

234 Nome original do conto "Das lembranças do Cáucaso. O degradado" (Из кавказских воспоминаний. Разжалованный).
} 
Comecei ontem as "Anotações do feierverker ${ }^{235 ",}$ mas hoje não escrevi nada. Terminei a "História" de Karamzin.

Estive lendo o conto de Pisemski "Lechi (Silvano)"236. Que linguagem extravagante e trama inverossímil!

Sulimóvski, com sua grosseria costumeira, contou-me como Pistolkors ${ }^{237}$ me injuria por causa de Rozenkrants; isto me magoou intensamente e arrefeceu minhas ocupações literárias mas, o anúncio do Sovremiênnik para o ano 1854, de novo, estimulou-me em relação a elas ${ }^{238}$.

17 de Dezembro. O dia inteiro estive lendo História ${ }^{239}$.

Ustrialov chama as peculiaridades do povo russo: fidelidade à fé, valentia, convicção da sua superioridade frente a outros povos, como se essa não fosse uma peculiaridade comum a todos os povos e como se o povo russo não tivesse peculiaridades distintivas.

É necessário explicar cada acontecimento histórico com expressões humanas e fugir das expressões históricas rotineiras.

Eu teria escrito esta epígrafe para a história: "Nada ocultarei". Para não mentir diretamente, é necessário esforçar-se em não mentir por omissão, calando-se.

19, 20 de dezembro. Ontem, apesar de sentir-me melhor, não escrevi nada.

\footnotetext{
235 "Anotações do feierverker" é um dos nomes originais do conto "A derrubada do bosque". A palavra feierverker provém do alemão Feuer (fogo) e Werker (trabalhador). Era o nome do grau militar de um sub-oficial e um posto na divisão de artilharia no exército do império russo e também em alguns outros exércitos estrangeiros. O cargo apareceu no exército russo desde começos do século XVIII e existiu até a revolução (Informação disponível em:

http://ru.wikipedia.org/wiki/\%D0\%A4\%D0\%B5\%D0\%B9\%D0\%B5\%D1\%80\%D0\%B2\%D0\%B5\%D1\%80\%D $0 \% \mathrm{BA} \% \mathrm{D} 0 \% \mathrm{~B} 5 \% \mathrm{D} 1 \% 80$

Último acesso: 25/07/09. N. do T.).

${ }^{236}$ O conto "Lechi”, de Aleksei Feofilaktovitch Pisemski, foi publicado no Sovremiênnik No 11 de 1853. Lechi, cuja tradução sugerida pelos dicionários, por aproximação com o folclore romano, é um reconhecido ser sobrenatural do folclore eslavo e dos contos maravilhosos russos. O nome Lechi provém da palavra russa les, bosque, lugar onde habita este espírito durante a temporada cálida do ano. Lechi hiberna sob a terra, mas antes de desaparecer durante o inverno, provoca tempestades, arranca árvores, espanta os animais e se torna furioso. Lechi tem o aspecto de um homem idoso de olhos verdes e está quase sempre acompanhado por um par de cães. Nós preferimos manter o nome russo. (Sobre Lechi ver http://ru.wikipedia.org/wiki/\%D0\%9B\%D0\%B5\%D1\%88\%D0\%B8\%D0\%B9 Último acesso, 20/07/09. N. do T.).

237 A. V. Pistolkors, colega de Tolstói. Foi representado no conto "A incursão" sob o nome do Tenente Rozenkrants.

${ }^{238}$ Em comunicado sobre os planos da redação do Sovremiênnik para o ano 1854, Tolstói é mencionado entre os reconhecidos escritores russos que colaboram de forma permanente com a revista.

${ }^{239}$ História russa de N. G. Ustrialov.
} 
Ao que me parece, a única coisa com que foi premiada a inatividade em que fiquei neste mês foi que o plano do Romance de um proprietário russo mostrou-se claramente. Antes, ao adivinhar a riqueza do conteúdo e a beleza das ideias, eu escrevia ao acaso. Não sabia que escolher entre a multidão de ideias e imagens tem a ver com essa matéria.

Ao ler o prefácio filosófico de Karamzin à revista "Útrennyi svet"240, que ele editava em $1777^{241}$ e onde ele afirma que o objetivo da revista é a filosofia, o desenvolvimento da inteligência humana, da vontade e do sentimento, dirigidos à virtude, eu fiquei admirado de como pudemos nós perder a noção do único objetivo da literatura -moral- até um grau tal que, se falarmos agora da necessidade de moral na literatura, ninguém entenderá. Em verdade, não estaria mal, como nas fábulas, escrever uma moral para cada obra literária, isto é, seu objetivo. $\mathrm{Na}$ "Útrennyi svet", inserem-se raciocínios sobre a imortalidade da alma, sobre o destino do homem, Fédon, a vida de Sócrates ${ }^{242}$ etc. Talvez nisso houve um exagero, mas agora caímos em situação pior.

Eis um objetivo nobre e, para mim, possível: publicar uma revista cujo único objetivo fosse a difusão de obras úteis. Na qual fossem aceitas obras sob a única condição de nelas existir uma moral, impressa ou não, dependendo da vontade do autor. Além disso, sem exceção, seria excluída a polêmica e a ridicularização de qualquer coisa, de forma que não existiria, por causa da sua própria orientação, choque com as outras revistas.

Alguém disse que o conhecimento da pintura é necessário ao poeta. Hoje, ao ler um ótimo artigo sobre a exposição ${ }^{243}$, entendi isso.

Para que uma obra seja atraente, não basta com que seja dirigida por uma ideia. É necessário que tudo esteja penetrado por um único sentimento. É isso o que eu não tinha em Adolescência.

\footnotetext{
${ }^{240}$ Luz matutina.

${ }^{241}$ Tolstói lia a revista "Útrennyi svet”, N 1, revista mensal publicada pelos Novikov em 1777. O prefácio a essa revista pertence não a Karamzim, mas a Novikov.

${ }^{242}$ Tolstói pensa aqui na tradução do diálogo de Platão Fédon, e no artigo "Biografia e peculiaridades socráticas" (Luz da manhã, 1777, $\mathrm{N}^{\circ} 1$ ).

243 Artigo de P. A. Aleksándrov "Resenha da exposição dos antigos produtos manufaturados em Moscou..." (Sovremiênnik, 1853, 9 e 10).
} 
21 de dezembro. De saúde, um pouco melhor, mas ainda não consigo acalmar-me. Amanhã irei para Kizliar, só se não passar por completo. Recebi carta de Zuev e Akrchiévski; ele não voltou a escrever e não me enviou Adolescência. Isto me enfurece. Adolescência vai de mal a pior: tem pouca coesão e a linguagem é ruim. Não li nada. Veio Sultanov e trocamos os cães.

29, 30, 31 de dezembro. No dia 29 estive de caça o dia inteiro e não matei nada. Ontem: estive escrevendo, pela manhã, o Romance de um proprietário russo, à tarde intoxiquei-me ${ }^{244}$ e dormi. Hoje, estive escrevendo o Romance de um proprietário russo pela manhã, à tarde fui de caça e nos banhos. Depois do jantar, escrevi cartas a Valerian e Tatiana Aleksándrovna.

Recebi o ano novo dedicado às cartas e depois rezei. Aliochka foi embora. Recebi uma carta de Valerian e Macha, que modificou meus sentimentos por ela ${ }^{245}$.

A forma, por mim adotada desde o próprio começo, de escrever pequenos capítulos, é a mais conveniente.

Cada capítulo deve expressar uma única ideia, um único sentimento.

\footnotetext{
${ }^{244}$ Para aquecer as casas no inverno, existe a estufa que possui um complexo sistema de encanamento para expulsar os gases tóxicos, produzidos pelo combustível, sem desperdiçar o calor. Nas estufas existe também um espaço apropriado para deitar-se. Quando não é corretamente acionado o sistema de encanamento, os gases tóxicos voltam para o interior da casa e as pessoas podem intoxicar-se (N. de T).

${ }^{245}$ A carta é desconhecida.
} 
2 de janeiro [Starogladkóvskaia] Levantei-me não muito cedo, estive escrevendo a manhã inteira o terceiro capítulo "O passado dele" ${ }^{, 246}$; parece bem, pelo menos escrevi com entusiasmo. Fiz a tolice de, depois do almoço, chamar Jukevitch que me interrompeu por duas horas. Depois estive escrevendo de novo, até às 10 horas. $\mathrm{O}$ trabalho vai muito bem.

Incluir no diário só as ideias, informações ou observações relativas aos trabalhos previstos. Ao começar cada trabalho, revisar o diário e extrair dele tudo o relativo a esse trabalho e anotá-lo em um caderno especial. Extrair as regras do diário a cada mês. Lembrar e anotar a lápis, todo dia, todas as violações contra as regras e incluí-las no diário.

4 de janeiro. Supunha-se que pela manhã ia escrever o Romance de um proprietário russo, à tarde "Anotações do feierverker", ir de caça se o clima fosse bom e pedir dinheiro. A manhã inteira estive escrevendo o Romance de um proprietário russo, mas tão pouco e tão mal, que continuei desde o entardecer até o jantar, mas só fiz borrões. Já depois do almoço estive lendo "Os inválidos"247. A conversa com os Voeikov não me sai ${ }^{248}$.

5 de janeiro. Pela manhã, escrever o Romance de um proprietário russo. Não só pela manhã, senão também depois do almoço, esmerei-me zelosamente no quarto capítulo e só escrevi diante do fogo, se bem não fiquei completamente satisfeito.

Com freqüência, na composição, detém-me o desejo de colar uma ideia boa ou bem expressada. Por isso, assim que uma ideia colar com o trabalho, incluí-la no diário, sem ficar com o desejo de colocá-la justo em algum lugar. A própria ideia achará seu lugar.

6 de janeiro. Pela manhã, Romance de um proprietário russo. Extrai do caderno velho o quinto capítulo "Ivan Tchuris", mas, sob pretexto do frio, estive com preguiça. Passear até $o$ almoço. Assim que saí, chamaram para o almoço; depois do almoço passeei, bebi café e brinquei com os meninos. Escrever "Anotações do feierverker" de artifício". Abri o caderno mas não escrevi nada e fiquei, até o jantar, conversando com Tchekatovski sobre os

\footnotetext{
${ }^{246}$ Terceiro capítulo da primeira redação do Romance de um proprietário russo.

247 Tolstói lia o jornal "O inválido russo".

${ }^{248}$ Voeikov é protagonista, nos rascunhos do esboço do Romance de um proprietário russo. (Obras completas reunidas, tomo 4 , pag. $309-362$ ).
} 
soldadinhos. Após o jantar, travou-se uma conversa metafísica. Depois do jantar, conversei alegremente com Iepichka.

A impassibilidade, isto é, sempre o mesmo olhar frio, constitui a sabedoria dos velhos.

O soldado Jdánov dá aos recrutas pobres, dinheiro e camisas. O atual feierverker, Rubin, antigo recruta que recebeu ajuda e instruções dele, disse-lhe; quando eu vou te pagar, titio? Se eu não morrer, você pode me pagar, agora se morrer, tudo fica por isso mesmo, respondeu-lhe 249 .

Encontrei um soturno soldado sem pernas e perguntei-lhe por que ele não tinha a $\mathrm{cruz}^{250}$. Dão as cruzes àqueles que limpam bem os cavalos, disse ele virando-me as costas. "E a quem prepara um mingau doce", aproveitaram, rindo, uns meninos que saíram atrás dele.

Spevak, um cabo, recebeu de Rubin 9 rublos de ouro para a manutenção. Ele foi passear e retirou-os do seu próprio dinheiro. À noite, roubaram-nos dele e, apesar que Rubim não o acusou, ele não parava de chorar, morrendo de tristeza. O recruta Zákharov pediu a Rubin que o tranquilizasse, oferecendo seu único rublo. O pelotão fez uma coleta e pagou a dívida $^{251}$.

7 de janeiro. Supus que, pela manhã, estaria de caça. Levantei-me suficientemente cedo, mas escrevi uma carta antes de ir de caça. As primeiras foram más, por isso não matei nada e voltei para o almoço. Veio Groman vai para Tíflis. Ele é um rapaz bom e honrado. Depois do almoço, escrever "Anotações do feirverker". Depois da partida dos oficiais, peguei no sono e dormi até a hora do chá. Veio Tchekatóvski e, de novo, me atrapalhou. Depois do jantar, fiquei em casa de Jukevitch e agora, vou me deitar de pois de não ter feito nada no dia inteiro.

O homem russo -ou, em geral, o homem simples- na hora do perigo, ama mostrar que ele sente mais medo, ou em verdade o sente, de perder seus encargos ou coisas pessoais do que a própria vida.

Iepichka e Guitchik partiram para a montanha ao cantar do galo e andaram até o amanhecer. Para saber onde estavam os auis e os rebanhos, Iepichka uivava como os lobos. Quando os cães responderam ao chamado, eles se aproximaram ao aul, prenderam os cavalos e os fustigaram para que fossem para a casa. Mas erraram muito e, por desgraça, não voltaram a casa até o amanhecer. Então Iepichka desceu do cavalo, soltou-o à frente, e dize-lhe que o

\footnotetext{
${ }^{249}$ Episódio do terceiro capítulo do conto "A derrubada do bosque".

${ }^{250}$ Tolstói se refere à Cruz de São Jorge, máxima distinção outorgada aos soldados e suboficiais pela valentia no combate (N. de T).

${ }^{251}$ A história de Spevak foi usada no conto "A derrubada do bosque", capítulo segundo.
} 
mataria se ele o enganasse. O cavalo o levou à stanitsa. Então, depois de prender os cavalos no abrunheiro, Guitchik fez passar Iepichka e este último fustigou e conduziu os cavalos às montanhas, vendeu-os por $1 / 10$ do preço, enfiou-se as notas nas botas e voltou.

8 de Janeiro. Pela manhã, o Romance de um proprietário russo. De alguma maneira, escrita não saiu. É necessário seguir a regra de excluir sem acrescentar. Almocei cedo. Passear. Passeei depois do almoço.

Escrever à tarde "Anotações do feierverker". Escrevi muito bem, mas comecei tarde, por causa do frio. Por duas horas, fiquei deitado na estufa. Estar sozinho. E ninguém veio. Um frio terrível atrapalha-me por segundo dia consecutivo.

É necessário escrever o rascunho, sem refletir sofre o lugar nem na exatidão da expressão das ideias. Reescrever por segunda vez, excluindo tudo o supérfluo e dando um lugar justo a cada ideia. Reescrever por terceira vez, arranjando a exatidão da expressão.

Evita os impropérios e os recontos.

Os soldados vestem peitilho de pano.

Evita cada movimento ou manifestação que possa ofender os outros.

12 de janeiro. Pela manhã, passear e o Romance de um proprietário russo. Levanteime muito tarde. Aqueci-me, quase me intoxiquei contra a estufa e o resfriado aumentou. Além disso, veio Ogolin e eu não escrevi nada. Passear. Cumpri. Depois do almoço. Ideias e regras. Ao chegar em casa, deitei-me na cama e adormeci. Ao despertar, abri o caderno e refleti, mas não terminei de escrever a ideia fundamental. A noite “Anotações do feirverker". Também abri o caderno mas, em lugar dos assuntos, estive sonhando com a guerra turca e com Calafat $^{252}$. Depois do jantar, soube que foi transferido para a brigada $12^{253}$ e resolvi passar por casa.

16 de janeiro. $O$ dia inteiro, Adolescência. Despertei tarde porque ontem escrevi até o cantar do galo. Ianuchkevitch já escreveu e Makalinski chegou assim que eu acordei. Não fui com ele a Kizliar e ordenei que era necessário ir com um soldado. Veio Ogolin, assim que não consegui nem rezar a Deus, e fui com ele passear. Voltei para a casa lá pelas 10 , corrigi um

\footnotetext{
${ }^{252}$ Lugar da Romênia, localizado à margem esquerda do Danúbio onde, à época, tinham lugar ações militares entre tropas russas e turcas.

${ }^{253}$ Por solicitação própria, Tolstói foi transferido para o Exército do Danúbio, destinado à bateria No 4,12 bateria da brigada de artilharia sob comando do coronel Nemov. A brigada se tornou efetiva do destacamento do Tenente-general P. P. Liprandi, que se precipitou sobre a cabeça da ponte Calafat.
} 
capítulo. Estive chateado até a hora do almoço e não perguntei sobre a cruz, que tanto me preocupa. Depois do almoço escrevi satisfatoriamente o capítulo $A$ amizade, corrigi o texto de Ianuchkevitch, de tal forma que hoje Adolscência deveria estar acabada. Estive nos banhos, jantei e vou me deitar. Estou um pouco chateado e não resolvi se vou ou não para Grózni. Recebi carta de Nikólenka e de Tatiana Aleksándrovna.

Uma obra parece sob uma luz completamente diferente e melhor quando está terminada.

Hoje me impressionou a beleza poética do clima invernal. Entre a névoa, que se eleva no céu, apenas branqueja um solzinho. No caminho, o estrume começou a degelar e no ar intensa concentração de umidade.

19 de janeiro [Schedrinskaia ${ }^{254}$ ]. (terça-feira) Concluir Adolescência e ir embora. Cumpri. Levantei-me cedo e, até a própria partida, estive ou escrevendo ou atarefado. Rezei um te-déum, por vaidade. Aleksiéev despediu-se de mim com muita amabilidade. Ele e Jukevitch derramaram umas lágrimas. Cheguei a Schedrinskaia. Reli Adolescência e decidi não voltar a olhar para ela até chegar em casa e pelo caminho escrever as caucasianas “Anotações do Feierverker".

Ontem me impressionou muito que todas as regras que eu, com tamanho esforço, me estabeleço, foram todas escritas, e muito melhor do que por mim na azbutchka ${ }^{255}$. Dessa forma, parece que, não as regras, mas a sua anotação, é uma ninharia. O journal de Franklin é outra coisa. Anotar os vícios importantes e esforçar-se por evitá-los. E escrever as ideias. A única mudança no estilo das minhas ocupações, passou a ser a substituição do caderno de regras pelo caderno de Franklin.

Hoje, ao pensar que comecei a gostar de pessoas que antes não respeitava, os meus camaradas, lembrei-me de como me parecia estranha a afeição de Nikólenka por eles. E a mudança da minha opinião, expliquei-a porque no serviço no Cáucaso e em muitos outros estreitos círculos, o homem aprende não a escolher as pessoas, mas a ver, inclusive nas más, o que há de bom.

Uma mulher cossaca contou-me que dizem que a Turquia se entregou.

Decidi fazer as seguintes correções em Adolescência:

\footnotetext{
${ }^{254}$ Schedrinskaia é a stanitsa onde, a caminho para o novo lugar de serviço (com uma parada em Iásnaia Poliana), Tolstói ficou no dia 19 de janeiro.

${ }^{255}$ Apostila de leitura com que as crianças aprendem a ler (N. de T.).
} 
1) Abreviar o capítulo "Uma viagem longa". 2) Em "A tempestade" (tormenta), simplificar as expressões e eliminar as repetições. 3) "Macha", fazê-lo decoroso. 4) Unir "A má nota" com "Chumbo". 5) "A chavinha", acrescentar aquilo que se encontra na pasta. 6) "O sonho com a mãe", mudar. 7) Achar um título para "Tudo tem jeito na vida". 8) "Dubkov e Nekhliúdov": mudar o começo e acrescentar uma descrição de nós próprios e da nossa disposição no momento das conversas ${ }^{256}$.

20 [de Janeiro. Stariy Yurt] Levantei-me cedo. Cheguei a Nikolaiévskaia e Stariy Yurt. A notícia de que não me concederam a cruz, afligiu-me muito; mas, coisa estranha, daí a uma hora estava tranquilo. Sulimóvski arranjou-me uma ocasião e amanhã irei, sem ficar.

21 de janeiro [Galiugaevskaia] Eis um fato para lembrar com frequência: Thackeray preparou-se para escrever se primeiro romance durante 30 anos e Alexandre Dumas escreve por volta de duas por semana.

Não é necessário mostrar minhas obras a ninguém, antes da publicação. Ouvem-se mais opiniões perniciosas que conselhos úteis.

22, 23, 24, 25, 26, 27 de janeiro. Estive de caminho. Dia 24, em Belogorodtsevskaia, a 100 verstas de Tcherkassk; errei a noite inteira. E me veio a ideia de escrever o conto "A nevasca". 257

28, 29, 30, 31 de janeiro, 1, 2 de fevereiro [Iásnaia Poliana] Estive duas semanas exatas em caminho. A única coisa surpreendente que me aconteceu foi uma nevasca. Comportei-me bastante bem. Meus erros foram: 1) Fraqueza com os viajantes. 2) Falsidade. 3) Covardia. 4) Zanguei-me duas vezes.

Nikólenka e Serioja não estão e eu quero tanto pensar, fazer e sentir, que vou escrever pouco no diário.

\footnotetext{
${ }^{256}$ A mairia das modificações assinaladas foi realizada. Alguns capítulos receberam nomes novos. Assim por exemplo, "O sonho com a mãe" foi chamado "O sonho"; O capítulo "Dubkov e Nekhiudov" foi chamado "os amigos de Volódia". Os capítulos "Chumbo" e "A má nota", não foram unidos. O capítulo "Tudo tem jeito na vida", manteve o antigo nome.

${ }^{257} \mathrm{O}$ conto "A nevasca" só foi escrito em fevereiro de 1856.
} 
2 de fevereiro. Despertei tarde, conversei com o estaroste e com Osip; encontrei tudo melhor organizado do que esperava. Dei uma volta pela propriedade. Não me sinto bem. Chegou Valerian.

[3 de fevereiro] 3 de janeiro ${ }^{258}$. Despertei cedo, me dói a garganta; apesar disso, fui ao moinho para examinar o melhor lugar para a estrebaria. Falei sobre a propriedade, mas do que tudo, enviei uma carta a Schelin. Dizem que fui promovido ${ }^{259}$.

4 fevereiro. Levantei-me cedo, depois de uma noite intranqüila e insone. Escrevi uma carta a Gote, fui à igreja, almocei, escrevi as prescrições e encontrei a titia. Não me sinto nada bem.

O defeito mais importante do meu caráter e a sua singularidade consiste em que eu, por demasiado tempo, fui moralmente jovem e só agora, aos 25 anos, começo a adquirir esse olhar independente sobre as coisas, isto é, um olhar de homem que outros adquirem muito antes, aos 20 anos.

6 de Fevereiro. Levantei-me cedo, dei algumas ordens, tomei 600 rublos em dinheiro para entregar no Conselho e fui para Tula. Encontrei Helke e pus fim ao assunto com ele, se bem não completamente bem, pelo menos satisfatoriamente ${ }^{260}$.

Acontecimentos de 17 [de janeiro] a 6 [de fevereriro]. Fui embora, no dia 19, para Stariy Yurt, soube do malogro da cruz. Fiz mal a viagem e errei uma noite memorável. Em 2 de fevereiro, cheguei a Iásnaia, cansado e doente, encontrei as coisas em ordem e a mim, tranqüilo, emendado e antiquado. Meus irmãos foram embora para Moscou. Arseniev morreu, Tcherkasski e Neratov se mataram às facadas ${ }^{261}$. No dia 6 estive em Tula, pus fim ao assunto com Helke e soube da minha promoção.

\footnotetext{
${ }^{258}$ Lapso evidente.

${ }^{259}$ Como distinção pelos combates contra os montanheses, no dia 9 de janeiro de 1854, Tolstói foi promovido ao grau de alferes.

${ }^{260}$ Ver nota 15 de 1851.

261 O príncipe K. A. Tcherkasski, proprietário da província de Tula, ao perder sua posição jogando cartas, suicidou-se. Também se suicidou, por causas desconhecidas, o jovem proprietário A. I. Neratov quem estudou com Tolstói na Universidade de Kazan.
} 
Tarefas. Concluir Adolescência. Decidi-me a destruir as anotações e pôr em ordem as regras. Inventei três regras necessárias para ter sucesso na vida. Tomei muitas previdências, escrevi algumas cartas, mas, em geral, afastei-se um pouco da ordem e das atividades.

8 de fevereiro [Pokróvskoe]. Saímos às 12 horas e chegamos às $9^{262}$. Não me comportei nada bem no caminho. Macha e a titia são adoráveis, e eu nem vi passar o dia.

10 de fevereiro. Levantei-me por volta das 9, fui para a casa dos fundos e lá escrevi a Aleksiéev, estive em casa da baronesa ${ }^{263}$ e, apesar de desastrado, não fui pudico. Depois do almoço escrevi o testamento ${ }^{264}$ e estive conversando.

13 de Fevereiro [Iásnaia Poliana](dia) 11 terminei o assunto do testamento e saí às 10, no caminho conversei muito agradavelmente com Vergani; em casa encontrei todos meus irmãos e os Perfílev. Mítenka me entristeceu e Serioja me alegrou. Recebi carta de Nekrásov. Ele não está satisfeito com "O conto do marcador"265. Não fiz nada nesses dois dias, mas passei-os muito agradavelmente, apesar da dor de garganta.

16, 17, 18 de fevereiro [Moscou] Não me lembro de nada, exceto que cheguei a Moscou. Desregrado física e moralmente e gastei demasiado.

14 de março de 1854. Bucareste ${ }^{266}$. Começo um novo caderno depois de quase um mês de intervalo, tempo durante o qual experimentei e passei por tanto que não tive tempo de pensar, tanto menos de anotar. Do Cáucaso, cheguei a Tula, vi as tias, a minha irmã, Valerian e soube da minha promoção. Meus três irmãos e os Perfiliev vieram ver-me e me levaram a Moscou. De Moscou passei por Pokróvskoe e lá me despedi da titia Pelagueia Ilínitchna, de Valerian, Macha e Serioja. Essas duas despedidas, especialmente a última, foram uns dos minutos mais felizes da minha vida. Daí, fui ver Mítenka quem, pelo meu conselho, quase

\footnotetext{
${ }^{262}$ Antes da partida para o Exército do Danúbio, Tolstói foi a Pokróvskoe passar uns dias em casa da sua irmã Maria Nikoláevna.

${ }^{263}$ A baronesa A. P. Delvig, irmã de V. P. Tolstói.

${ }^{264} \mathrm{O}$ testamento for escrito por ocasião da partida para a guerra. Não foi conservado.

${ }^{265}$ Em carta de 6 de fevereiro de 1854, Nekrásov escreveu que "As anotações do marcador" era "muito bom quanto à ideia, mas muito fraco quanto à execução. Isso é culpa... da forma escolhida" A linguagem do marcador, "não tem nada característico"... "O conto saiu tosco e o melhor dele se perdeu" (Nekrásov, tomo 10, pag. 201).

${ }^{266}$ Tolstói chegou em 12 de março a Bucareste, ao estado-maior do Exército do Danúbio, para receber sua designação para o novo lugar de serviço.
} 
deixou Moscou e, por Poltava, Kishinev etc., em três dias cheguei a Bucareste. Eu fui feliz todo esse tempo!

A minha situação de serviço aqui não está definida e eu de novo, há uma semana, estou duvidosamente doente. Será possível que, de novo, comece para mim um período de prova?

Por outro lado, eu sou o culpado; a felicidade estragou-me com mimos: eu tenho caído muito e posso reprochar-me por muita coisa desde o dia da minha partida de Kursk até este minuto. É triste convencer-se de que eu não fui capaz de suportar a felicidade, tal como não fui capaz de suportar a infelicidade. Hoje, irei ver o comandante da divisão no corpo do estado-maior, farei algumas compras, passearei e voltarei a casa para escrever umas cartas e almoçar. Depois do almoço, ocupar-me-ei em alguma coisa e antes da noite irei aos banhos. À noite, ficarei em casa e dedicar-me-ei a Adolescência. 


\section{Considerações finais}

A ideia de trabalhar com os diários de juventude de Liev Tolstói surge do interesse de aproximar-se de uma faceta menos conhecida do autor russo. A leitura dos diários revela logo um filão precioso de temas que exigem atenção. Tolstói, afirma Chklóvski, é um autor programático, e se lhe tivessem faltado os assuntos para a composição literária, nos seus diários poderia achar a matéria necessária para criar as suas obras. Sem exceção, todos os estudiosos dos diários de Tolstói encontram neles "o embrião de toda a sua criação futura" (Eikhenbaum, 1987, pag. 67). Porém, uma vez colocado o desafio de trabalhar com esses diários, aparece a questão de compreender a natureza do texto e o lugar dele dentro do universo da criação Tolstoiana.

Para responder a tais questões, a análise das características do diário como gênero literário, possibilitou a compreensão do texto de Tolstói não só como obra de não ficção em que são visíveis "características estilísticas cuja tendência depende das condições de vida e da disposição psicológica do autor” (Egorov, 2002, pag. 190). O Diário do jovem Tolstói se revela como texto atônomo, com mais de uma "linha de enredo" (Buchkánets) e características estilísticas próprias: dos aforismos filosóficos do século XVIII às descrições da natureza, dos caracteres e da psicologia que se tornariam caracaterísticas dos romances do autor russo.

Os diários se revelam assim em uma dupla função de revelador dos procedimentos da criação tolstoiana e do processo de formação do seu pensamento, da consciência do próprio eu:

Pensei em que escrevo o diário não para mim, mas para as pessoas, principalmente, para aquelas que vão viver quando eu não estiver -corporalmente- e em que não há nada de mau nisso, naquilo que se pensa de mim e que se exige de mim. Mas, e se ardessem esses diários? E quê! Eles talvez são necessários para os outros e para mim talvez não é que sejam necessários, mas eles são eu. Eles constitue meu bem (Tolstói, 2009, 193). 


\section{REFERÊNCIAS}

\section{OBRAS DE TOLSTÓI}

Толстой, Лев Николаевич. Полное 90-томное собрание сочинений, 2009. (Obras completas em 90 tomos, 2009).

Disponível em: http://petrovitskaya.lifeware.ru/sobranie sochineniy Último acesso em 20/12/2010.

Tolstói, Liev Nikoláevitch. Sobranie sotchinenii v dvadtsati tomakh. Moskva:

Khudojestviénnaia Literatura, 1965.

.Obras. Tomos 1 y 2. Versión directa del Ruso, prólogo bibliográfico y notas de Irene y Laura Andresco. Madrid: Aguilar s.a. de ediciones, 1973.

.As obras primas de Leon Tolstói. Traduções de Marques Rebelo, Boris

Schnaiderman e Ruy Jungman. Rio de Janeiro: Ediouro, 2000.

.Diarios. Edición y traducción de Selma Ancira. México: Ediciones Era, 2001.

.Anna Kariênina. Tradução de Rubens Figueiredo. São Paulo: Cosac Naify, 2005.

\section{OBRAS SOBRE TOLSTÓI}

Berlin, Isaiah. El erizo y la zorra: ensayo sobre la visión histórica de Tolstoi.

presentación de Mario Vargas Llosa ; traducción de Mario Muchnik.

Buchkánets, L.E. “Dnevnik molodogo Tolstogo”. Kazan, [20--?]

Chklóvski, Víktor. Energia zablujdenia. [S.1.]: Sovietski pisatel, 1980.

Dneprov, V. "É necessário um ideal para a vida" (Tolstói nos seus Diários). In: Questão de literatura, No. 8. pag. 88, 1978.

Dvoichenko-Markov, Eufrosina. Benjamin Franklin and Leo Tolstoy. In: American Philosophical Society, Vol. 96, No. 2 p. 119-128, 21 de abril de 1952.

Disponível em: http://www.bases.unal.edu.co:2065/stable/3143718 Acesso em 21/03/2010. 
Êikhenbaum, Boris. O literature. Raboty raznykh let. Mosckva. Sovietski pisatel, 1987. .Tolstoi do Voiny i mira. In: Molodoi Tolstoi-vospominaniya, pisma,

dnevniki... Moskva: Agraf, 1999.

Mann, Thomas. Goethe y Tolstoi: (acerca del problema de la humanidad).

Traducción directa del alemán por Sara C. Roll. [S.1.: s.n.], 1955.

Paperno, Irina. Tolstoy's Diaries: The Inaccessible Self. Ithaca: Cornell University Press, 2000.

Porché, Francois. Tolstoi: retrato psicológico [S.1.: s.n.], 1958.

Rolland, Romain. Introducción a la vida de Tolstoi. [S.1.: s.n.], 1928.

Séché, Alphonse. Tolstoy: 36 retratos y documentos. Traducción de M. Aguilar Muñoz. [S.1.: s.n.], 1960.

Sender, Ramón José. Tres ejemplos de amor y una teoria. [S.1.: s.n.], 1969.

Steiner George. Tolstói ou Dostoievski: um ensaio sobre o velho critisismo. São Paulo:

Perspectiva, 2006.

Tolstaia, Alexandra Lvovna, condesa. Tolstoi: una vida de mi padre. Traducción de Pedro Lecuona. [S.1.: s.n.], 1956.

Zuleta, Estanislao. La propiedad, el matrimonio y la muerte en Tolstoi. con presentación de Oscar Espinosa. [S.1.: s.n.], 1980 / 92.

Zweig, Stefan. Tolstoi: (Tres poetas de su vida. Traducción directa por Joaquín Verdaguer. [S.1.: s.n.], 1950.

\section{OBRAS GERAIS}

Amiel, Henri-Frédéric. En torno al diario íntimo. Valência: Pré-textos Narrativa, 1996. Auerbach, Erich. Mímesis. México: Fondo de Cultura Económica, 1996.

Berdiáev, Nikolái. “La idea rusa (problemas fundamentales del pensamiento ruso 
del siglo XIX y de principios del siglo XX)", en Rusia y occidente. Madrid: Tecnos: 215 320, 1997.

Bíblia de Jerusalém. São Paulo: Paulus, 2008

Bobrova, Nina. Dnevnik K. I. Tchukovskogo v istoriko-literaturnom kontekste. Avtoreferat dissertatsii na soiskanie utchenoi stepeni kandidata filologitcheskikh nauk.

Castilla del Pino, Carlos. "Teoría de la intimidad", en Revista de Occidente. No 182 - 183. p. 15-31. Madrid, Jul - Ago. De 1996.

Chizhevski, Dmitri. Historia del espíritu ruso. Vol 2. Madrid: Alianza Editorial, 1967.

Egorov, Oleg. Dnevniki russkikh pisatelei XIX veka. Moskva: Flinta - Nauka, 2002.

Eliot, T. S. Ensayos escogidos. México: Universidad Nacional Autónoma de México, 2000.

Frank, Joseph. Pelo prisma russo. Ensayos sobre literatura e cultura. São Paulo: Edusp, 1990.

Freixas, Laura. “Áuge del diario ¿íntimo? en España”, en Revista de Occidente. № 182 - 183:

5-15. Madrid, Jul - Ago. De 1996.

Girard, Alain. Le journal intime. Paris: Presses universitaires de France, 1963. . "El diario como género literario", en Revista de Occidente. No 182 - 183. p. 31-39.

Madrid, Jul - Ago. de 1996.

Goldmann, Lucien. El hombre y lo absoluto: el dios escondido. Traducción de JuanRamón Capella. Barcelona: Ediciones Península, 1968.

Marchand, René. El humanismo cristiano en la evolución de la literatura rusa. México:

UNAM, 1961.

Nabokov, Vladimir. Curso de literatura rusa. Traducción de María Luisa Balseiro. España: Ediciones B, Grupo Z, 1997.

Paperno, Irina. What Can Be Done with Diaries? Russian Review, Vol. 63, No. 4 p. 561-573, October 2004.

Disponível em: http://www.jstor.org/stable/3663979. Acesso em 30/03/2010.

Platón. Diálogos. Obra completa en 9 volúmenes. Volumen III: Fedón. Banquete. 
Fedro, Madrid: Editorial Gredos, 2003.

Smirnova, L. A. Literatura rusa del fin del siglo XIX y comienzo del siglo XX.

Moscú: Lakom-Kniga, 2001.

Vários. Rusia y Occidente. Antología de textos. Estudio preliminar y selección,

Olga Novikova. Traducción y notas, Olga Novikova, José Carlos Lechado, 1997.

\section{DICIONÁRIOS}

Abby Lingvo Англо-русский / русско-английский словарь. (Dicionário anglo - russo / russo-inglês). [S.1.: s. n.].

AlphaLex 5.0 portuguese. [S.1.]: Medialingva, [20--?].

AlphaLex 5.0 spanish. [S.1.]: Medialingva, [20--?].

Aulete Digital, dicionário contemporâneo da língua portuguesa. [S.1.]: Lexikon, [20--?].

Houaiss, A. Diconário Eletrônico Houaiss da língua portuguesa 1.0. Editora Objetiva, 2001.

Ожегов, С. И.; Шведовой, Н. Ю. Толковый словарь русского языка. (Ojegov, S. I.;

Chvedovoi, N. Iu. Dicionário da língua russa). [S.1.: s. n.].

Voinova, N. et al. Dicionário Russo-português. Moscovo: Edições Russki Yazik, 1989. 


\section{Anexo}

\section{Algumas dificuldades da tradução}

Visto que a essência do presente trabalho é a tradução dos diários de juventude de Tolstói, consideramos interessante ilustrar com alguns exemplos a natureza do próprio processo da tradução, mostrando algumas das dificuldades típicas que encarna o trabalho de tradução da língua russa para o português.

\section{Léxico}

Segundo o dicionário Russo - português, a palavra переход (perekhod) quando indica movimento de um sítio a outro traduz-se como traslado, travessia, passagem, trajeto. Perekhod é o substantivo designador da ação expressa pelo verbo de aspecto imperfeito de movimento perekhodit (perfeito, перейти pereiti) que significa, no dado contexto, ir - vir de um lugar a outro.

A língua russa enfatiza o processo da ação, entenda-se, a ação no seu desenvolvimento, ao passo que a portuguesa privilegia o resultado da ação. No trecho “ежели мой переход из клиники дамой мог произвести на меня такое влияние [...]" perekhod não se traduziu como "traslado", "travessia", "passagem", "trajeto" porque:

1) O sujeito do movimento não teve de vencer nenhum obstáculo natural (desfiladeiro, curso de água, terreno difícil etc.), o que elimina o segundo e o terceiro substantivos;

2) O autor das linhas citadas não precisou de ajuda para executar o movimento, isto é, ele não foi removido: ele é o sujeito do movimento. Portanto, exclui-se o substantivo "traslado", que só se aplica a pacientes do movimento, como no exemplo:

“Amanhã será o traslado dos restos mortais do escritor para a cidade de Taubaté". "O general providenciou o traslado dos feridos para outro hospital”.

3) No momento de escrita do diário, o movimento já estava concluído, o que por si só elimina completamente a possibilidade de uso de "trajeto".

Em vista do dito, a única tradução possível, parece-nos, é "vinda": "Se a minha vinda da clínica para casa pôde ter em mim tal influência”. 
A palavra perekhod torna a aparecer no mesmo período:

“Ежели мой переход из клиники дамой мог произвести на меня такое влияние, какое же влияние произведет на меня мой переход от жизни студенческой к жизни помещичьей?".

Agora, não se trata de movimento físico de um sítio a outro, mas de mudança de uma condição a outra. Essa transição é correntemente designada pela palavra "passagem": "passagem da infância para a vida adulta", passagem de capitão a major".

Assim, na segunda oração “какое же влияние произведет на меня мой переход от жизни студенческой к жизни помещичьей”, a palavra perekhod deve traduzir-se como passagem.

Assim, a mesma palavra (переход) teve duas traduções diferentes num mesmo período:

"Se a minha vinda da clínica para casa pôde ter em mim tal influência, que influência terá então sobre mim a passagem da vida de estudante para a vida de proprietário de terras?”

\section{O uso dos artigos}

A língua russa não possui artigos. Mas a presença, ausência e uso deles, na língua portuguesa, comporta um valor semântico fundamental que é imediatamente percebido pelo leitor nativo de língua portuguesa. No processo de tradução, contudo, o tradutor depara-se com um problema de escolha, pois não sempre encontra no texto original, em língua russa, todos os indícios necessários que lhe confirmam o uso apropriado dos artigos em uma determinada situação. Por exemplo,

“Перемена в образе жизни должна произойти. Но, нужно, чтобы это перемена не была произведением внешних обстоятельств, но произведением души”.

"Uma mudança no modo de vida deve acontecer. Mas é necessário que essa mudança não seja obra de circunstâncias exteriores, mas obra da alma”.

Mas não poderia ser também "das circunstâncias”? 
O emprego da preposição de desacompanhada de artigo significa a possibilidade de as circunstâncias exteriores não virem a ter nenhuma influência na vida do autor das linhas. Tanto que, em tal situação, sói empregar-se o adjetivo "eventual” ("de eventuais circunstâncias...”). Foi isso que motivou a nossa escolha.

A tradução também poderia ser, perfeitamente, "das circunstâncias exteriores". Em tal caso, o autor expressaria a crença numa grande probabilidade de as circunstâncias exteriores virem a ter influência na vida humana. Ademais, ficaria sugerido que todas as circunstâncias exteriores possuem a capacidade de fazê-lo.

Vejamos agora um problema mais complexo em que os dicionários da língua russa não contemplam um significado que o escritor dá a determinada palavra. Eis um trecho do caderno de regras de Tolstói, referente ao período março - maio de 1847:

\begin{abstract}
Воля бывает на различных ступенях развития, смотря по тому, над какой частью человека она преобладает. Три главные момента ее владычества суть: преобладание над телом, преобладание над чувствами и над разумом. В каждый момент ее преобладания она сливается в одно с той частью человека, над которой она преобладает, так что уже не существует более этой части самостоятельно, а существует только воля, одаренная способностями этой части человека.

Ежели воля преобладает над телом, что есть низшая ступень ее развития, то тело перестает существовать самостоятельно, а существует одна воля телесная. Ежели она преобладает над чувствами, то ни тело, ни чувства более не существуют самостоятельно, а существует одна воля телесная и чувственная, ежели же воля преобладает над разумом, то разум перестает существовать самостоятельно, а существует одна воля телесная, чувственная и разумная.
\end{abstract}

Traduziu-se como:

A vontade existe em diferentes graus de desenvolvimento, de acordo com a parte do homem sobre a qual predomina. Os três aspectos principais do seu domínio são: predomínio sobre o corpo, predomínio sobre os sentimentos e predomínio sobre a razão. Em cada aspecto do seu predomínio, ela se funde em um todo com a parte do homem sobre a qual predomina, de forma que tal parte já não existe autonomamente, mas existe apenas a vontade dotada das capacidades dessa parte do homem. Se a vontade predomina sobre o corpo, o que constitui o nível mais baixo do desenvolvimento dela, então o corpo deixa de existir de forma autônoma e passa a existir somente a vontade corporal. Se ela predomina sobre os sentimentos, então já não existirão nem o corpo nem os sentimentos de forma autônoma, mas uma vontade corporal e uma vontade afetiva ${ }^{267}$. Já se a vontade predomina sobre a razão, então a razão deixa de existir autonomamente e existe só a vontade corporal, afetiva e racional.

${ }^{267}$ Entenda-se "afetivo" na acepção de "relativo aos afetos, aos sentimentos" (Dicionário Eletrônico Houaiss da língua portuguesa. Versão 1.0). 
Como pode ver-se, o substantivo чувство (sentido; sentimento) е o adjetivo чувственный, (sensorial, sensitivo), de mesmo radical, foram traduzidos por palavras portuguesas de radicais diferentes: sentimento e afetivo, respectivamente. E isso foi feito ao arrepio da orientação dos dicionários. Pelo motivo que segue:

Temos o substantivo “чувство”, que além de sentimento, também significa sentido, е о adjetivo “чувственный”. Ao contrário do que parece, tal adjetivo não tem nenhuma relação com o substantivo чувство - sentimento, de acordo com os dicionários da língua russa consultados:

ЧУВСТВЕННЫЙ, -ая, -ое; -вен, -венна. 1. полн. ф. Воспринимаемый органами чувств (видимый, слышимый, осязаемый, обоняемый, воспринимаемый на вкус), относящийся к такому восприятию. Чувственное восприятие. 2. Плотский, с сильно выраженным половым влечением. Чувственные удовольствия. Ч. взгляд (Толковый словарь русского языка С. И. Ожегов).

Literalmente, SENSORIAL. 1. Percebido pelos órgãos dos sentidos (visível, audível, tangível, de que se consegue perceber o cheiro e o gosto), relacionado com tal percepção. Percepção sensorial. 2. Carnal, com forte expressão de atracão sexual. Prazeres sensuais. Olhar sensual. (Dicionário da Língua Russa de S. I. Ójegov).

O Dicionário de Russo - Português traduz o adjetivo ұувственный como sensorial, sensitivo. 2. Sensual, lascivo, voluptuoso.

Como pode ver-se, nenhum dos dicionários citados relaciona o adjetivo чувственный com o substantivo чувство - sentimento. Acontece, porém, que Tolstói, no trecho citado, alude a corpo em contraposição à esfera dos sentimentos. Isso impede-nos de traduzir o adjetivo чувственный, neste caso, como sensorial, sensitivo, nem, evidentemente, e muito menos, como sensual, lascivo.

De acordo com as definições dos dicionários Caldas Aulete, Aurélio e Houaiss, Sensorial refere-se a sensório ou a sensação, ou seja, é adjetivo referente aos órgãos dos sentidos ou à anatomia do cérebro. Não se refere, portanto, à esfera dos sentimentos. Que fazer nesse caso? 
Depois de consultar a tradução espanhola do referido trecho do diário de Tolstói, verificamos que a tradutora mexicana Selma Ancira resolvera a contento o problema, traduzindo o adjetivo чувственный como "afectivo":

La voluntad existe en distintos grados del desarrollo, según la parte de la persona en la que predomine. Los tres campos principales de su imperio son: el predominio sobre el cuerpo, el predominio sobre los sentimientos y el predominio sobre la razón. En cada campo en el que predomina se funde en un todo con la parte de la persona sobre la que predomina, de modo que esa parte deja de existir de manera independiente, y sólo existe la voluntad, dotada de las capacidades de esa parte de la persona.

Si la voluntad predomina sobre el cuerpo, lo que es el escalón más bajo de su desarrollo, el cuerpo deja de existir de forma independiente y sólo existe la voluntad física. Si predomina sobre los sentimientos, entonces el cuerpo y los sentimientos dejan de existir de forma independiente y sólo existe la voluntad física y afectiva. Si la voluntad predomina sobre la razón, entonces la razón deja de existir de forma independiente y sólo existe la voluntad física, afectiva y racional.

Decidimos adotar tal solução, pois o adjetivo português afetivo traduz apropriadamente a ideia do original russo, contemplando a esfera dos sentimentos, conforme uma das acepções que lhe dá Antônio Houaiss: "relativo aos afetos, aos sentimentos". 